\title{
A FULL CATALOGUE AND ANALYSIS OF PHOTOGRAPHS AND PHOTOGRAVURES BY ROBERT J. FLAHERTY AT THE ART GALLERY OF ONTARIO
}

\author{
by
}

Zulay Jau Ting Chang, BFA, Emily Carr University, 2005.

A Thesis Project

presented to Ryerson University and Art Gallery of Ontario

in partial fulfillment of the

requirements for the degree of

Master of Arts

in the Program of

Photographic Preservation and Collections Management

Toronto, Ontario, Canada, 2010

CZulay Jau Ting Chang 2010 
I hereby declare that I am the sole author of this thesis or dissertation.

I authorize Ryerson University to lend this thesis or dissertation to other institutions or individuals for the purpose of scholarly research.

I further authorize Ryerson University to reproduce this thesis or dissertation by photocopying or by other means, in total or in part, at the request of other institutions or individuals for the purpose of scholarly research. 
A Full Catalogue and Analysis of Photographs and Photogravures

by Robert J. Flaherty at the Art Gallery of Ontario

Master of Arts, 2010

Zulay Jau Ting Chang

Photographic Preservation and Collections Management

Ryerson University / Art Gallery of Ontario

\begin{abstract}
This thesis is based on a photographic collection at the Art Gallery of Ontario that comprise fifty-one photographs and photogravures by the filmmaker and photographer, Robert J. Flaherty (1884-1951). The objects consist of three groups: twenty-three photographs and nineteen photogravures of northern Arctic scenes and portraits; two presently unattributed photographs of northern scenes that are associated with Flaherty's work of the north; and seven portraits of Canadian artists Frances Loring (1887-1968) and Florence Wyle (1881-1968) taken in Toronto, Ontario. All the photographs were taken between 1910 and 1921; the photogravures were published in 1922, in portfolios titled, Camera Studies of the Far North.
\end{abstract}

This thesis has five components: a biography of Flaherty, literature review of what is presently known about Flaherty and his photography, a brief description of Flaherty's photographs in public institutions, a full catalogue of the fifty-one objects, which is fully illustrated and includes comparative illustrations of related objects examined at the Library and Archives of Canada in Ottawa, and an analysis of three photographs from each of the Flaherty groupings at AGO, primarily based on the research from the catalogue. 


\section{Acknowledgements}

There are many people whom I must thank for their time, their help and support they have given me on this project. I must also thank the professors and staff at Ryerson and at AGO, who I had the pleasure of working with and learning from during the course of my studies.

To David Harris, my thesis advisor and professor, I cannot thank him enough for all of his patience, encouragement and hard work in editing this project. I am really appreciative for all of his input and advice.

To Alison Nordström, my second reader for this project, for being excited to read my thesis and the input she gave me.

At AGO, I must thank Maia-Mari Sutnik, Curator of Photography, for piquing my interest in Robert Flaherty's photographs and answering my many queries about his work; Sophie Hackett, Assistant Curator of Photography, for allowing access to the prints whenever I needed; Liana Radvak, Manager of Collections Information \& Resources, for helping me understand TMS; and Jane Rhodes, Visual Resources Cataloguer of Image Resources for supplying the Flaherty images. Everyone at AGO had been very helpful and kind, not just for this project, but also throughout my second year studies in the program.

At Library and Archives of Canada, to Joanne Guillemette, Archivist, for her time and for retrieving all the materials. At the Robert and Frances Flaherty Study Center in 
Claremont, California, to Dr. Jack Coogan, for taking the time to answer my queries by email.

At Ryerson, I would like to thank all of my professors: Robert Burley, Marta Braun, Vid Ingelevics, Mike Robinson, Chris Evans and Thierry Gervais. I also want to thank Peter Higdon, who took us around Paris for the France workshop. Lastly, Jenn Park for her help and advice on just about everything! We would be lost without you.

I want to thank Jennifer Wong Barrera for editing and reading my papers. She always offered a fresh perspective and her input has been invaluable.

Lastly, I want to thank my family, friends and S.L. for all of their encouragement and support. 


\section{Dedication}

This thesis is dedicated to my grandmother, Kam Lan Chan $(1929-2009)$. She was the hardest working person I know and reminds me that nothing in life is impossible. 


\section{Table of Contents}

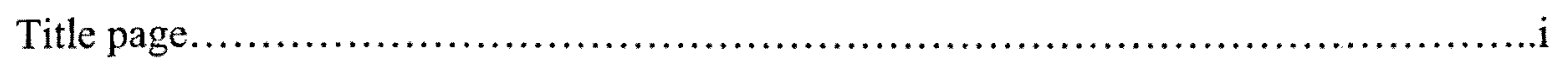

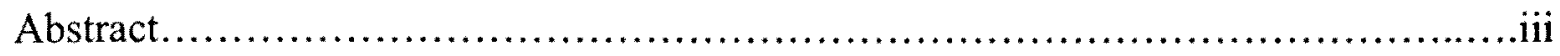

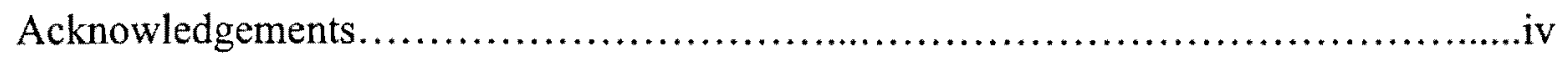

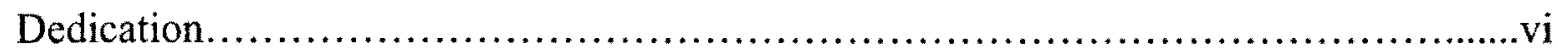

List of Maps \& Illustrations..........................................................

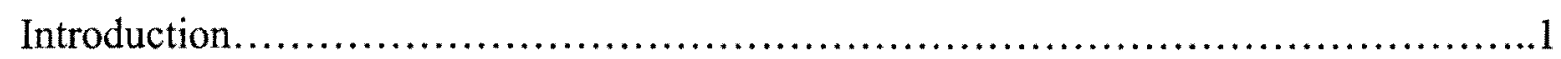

Methodology and Research Process..............................................4

Map of Northern Ontario and the Southern Hudson Bay region........................9

Map of the Hudson Bay and Baffin Island area...................................... 10

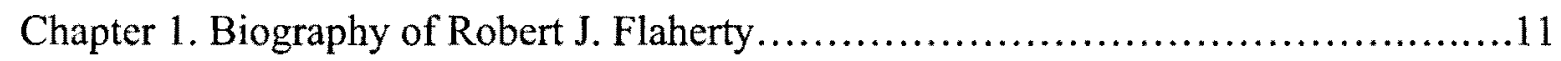

Chapter 2. Literature Review.............................................................. 16

Chapter 3. Holdings of Robert J. Flaherty's Photographs in Public Institutions..............23

Catalogue

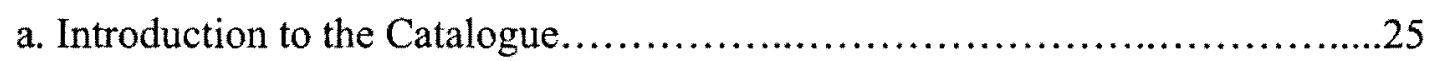

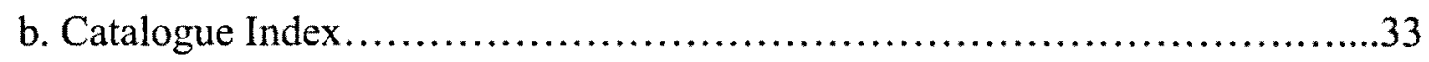

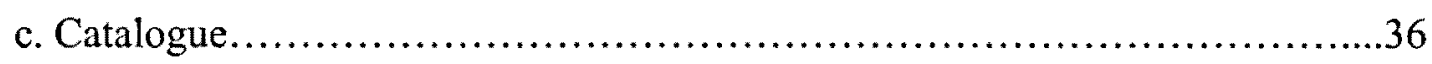

Photographs of the North (1910-1921)

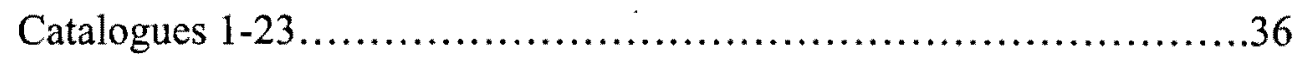

Photogravures of the North (1921-22)

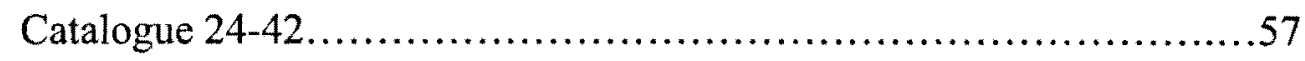

\section{Unattributed Photographs of the North}

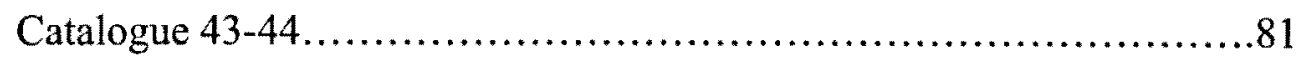




\section{Portraits of Frances Loring and Florence Wyle}

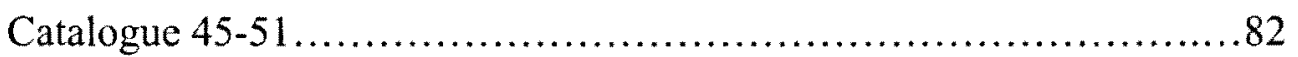

Chapter 4. Analysis of Selected Works by Robert J. Flaherty at the AGO......................90

a. Photographing the North from 1910-1916 and 1921-1922 _................90

b. Analysis of the Negative, Photograph and Photogravure........................92

c. Organization of the negatives and dissemination of the photographs

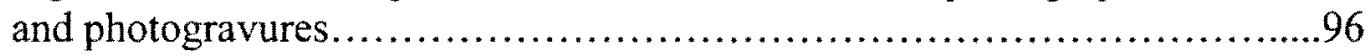

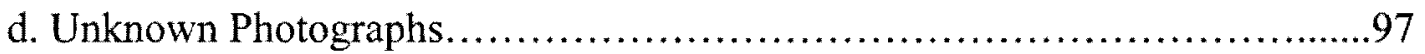

e. Frances Loring and Florence Wyle Photographs...............................99

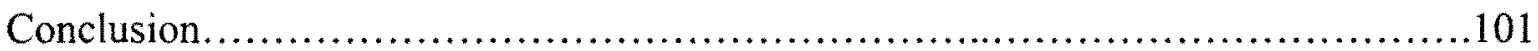

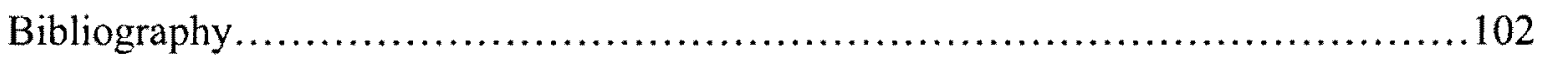

Appendix A: The complete portfolio of Camera Studies of the Far North..............104

Appendix B: List of works in the Flaherty collection at AGO from album............119

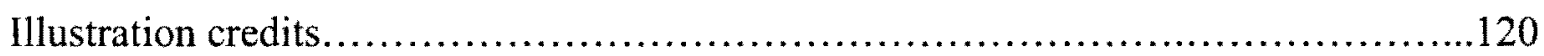




\section{List of Maps \& Illustrations}

Map of Northern Ontario and the Southern Hudson Bay Region.........................

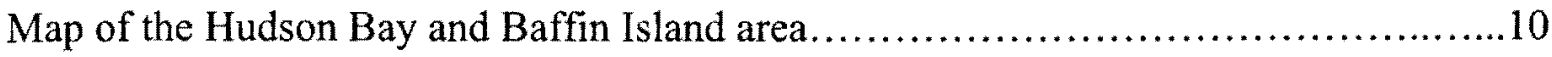

\section{Photographs \& Photogravures of the North (1910-1921)}

Catalogue 1. Robert J. Flaherty, Unidentified (Young Woman), Baffin Island,

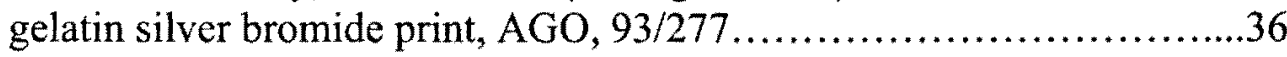

Figure 1. Robert J. Flaherty, [Unidentified Woman], gelatin silver glass plate negative, LAC, PA-500796

Figure 2. Robert J. Flaherty, [Unidentified Woman], gelatin silver glass plate negative, LAC, PA-500796 (verso)

Catalogue 2. Robert J. Flaherty, Two Women Carrying Wood, James Bay?, gelatin silver bromide print, $\mathrm{AGO}, 93 / 278$

Catalogue 3. Robert J. Flaherty, Unidentified Portrait of Inuit Child, gelatin silver bromide print, $\mathrm{AGO}, 93 / 279$

Catalogue 4. Robert J. Flaherty, Unidentified (Man), Baffin Island, gelatin silver bromide print, $\mathrm{AGO}, 93 / 280.1$

Catalogue 5. Robert J. Flaherty, Enutsiak (Innutsiak), Baffin Island, gelatin silver print, AGO, 93/280.2.

Figure 3. Robert J. Flaherty, [Woman identified as Enutsiak / Innustiak], gelatin silver glass plate negative, LAC, PA-114089

Figure 4. Robert J. Flaherty, [Woman identified as Enutsiak / Innustiak], gelatin silver glass lantern slide, LAC, PA-114220.

Catalogue 6. Robert J. Flaherty, Man (possibly Ezechiak), Baffin Island, gelatin silver bromide print, $\mathrm{AGO}, 93 / 280.3$

Catalogue 7. Robert J. Flaherty, Nascaupie Indian Chief, Northern Labrador, gelatin silver bromide print, $\mathrm{AGO}, 93 / 280.4$.

Catalogue 8. Robert J. Flaherty, Tooktoo (The Deer), Chief of Sikoslingmuit Eskimos identified as Anumniuq, Southern Baffin Island, gelatin silver bromide print, $\mathrm{AGO}, 93 / 280.5$ 
Figure 5. Robert J. Flaherty, [Man identified as Anumniuq], collodion printing-out paper, LAC, PA-121985.

Figure 6. Robert J. Flaherty, [Man identified as Anumniuq], gelatin silver glass lantern slide, LAC, PA- 121985 .

Catalogue 9. Robert J. Flaherty, Sada, Sikoslingmuit Eskimo of Southern Baffin Land, gelatin silver bromide print, AGO, 93/280.6.

Catalogue 10. Robert J. Flaherty, (Mother and Two Children), Ungava Peninsula?, toned gelatin silver print, AGO, 93/280.7.

Figure 7. Robert J. Flaherty, [Mother and Two Children], gelatin silver glass lantern slide, LAC, PA-114239.

Catalogue 11. Robert J. Flaherty, Landscape, River, gelatin silver bromide print, AGO, 93/280.8

Figure 8. Robert J. Flaherty, [View of Landscape and River], gelatin silver glass plate negative, LAC, PA-143312.

Figure 9. Robert J. Flaherty, [View of Landscape and River], gelatin silver print, LAC, PA-143312.

Catalogue 12. Robert J. Flaherty, Seated Eskimo over Seal Breathing Hole - with Harpoon, gelatin silver bromide print, AGO, $93 / 280.9$ .46

Figure 10. Robert J. Flaherty, [Unidentified Person Seated with Harpoon], gelatin silver glass lantern slide, LAC, PA-114272 ....................46

Catalogue 13. Robert J. Flaherty, Unidentified Inuit Child (Ungava Peninsula, Quebec), toned gelatin silver print, AGO, 93/280.10

Figure 11. Robert J. Flaherty, Unidentified Inuit Child, gelatin silver glass plate negative, LAC, PA-114101 (recto).

Figure 12. Robert J. Flaherty, Unidentified Inuit Child, gelatin silver glass plate negative, LAC, PA-114101 (verso).

Figure 13. Robert J. Flaherty, Unidentified Portrait of Eskimo Boy, gelatin silver glass lantern slide, LAC, PA-114241 
Catalogue 14. Robert J. Flaherty, Unidentified (Young Girl with Plaid Shawl) Ungava Peninsula, gelatin silver bromide print, AGO, 93/280.11

Catalogue 15. Robert J. Flaherty, Unidentified (Man in Profile), Fort Chimo?, gelatin silver bromide print, AGO, 93/280.12.

Figure 14. Robert J. Flaherty, Unidentified Portrait of a Man, most likely Naskapi Indian, LAC, gelatin silver print, PA-143717. 50

Figure 15. Robert J. Flaherty, Unidentified Portrait of a Man, most likely Naskapi Indian, LAC, gelatin silver print (hand-coloured), PA-143717.

Catalogue 16. Robert J. Flaherty, Unidentified Naskapi or Montagnais Indian with Snowshoes on his back, Fort Chimo, toned gelatin silver bromide print, AGO, 93/280.13.

Catalogue 17. Robert J. Flaherty, Unidentified (Child), Baffin Island, gelatin silver bromide print, AGO, 93/280.14

Figure 16. Robert J. Flaherty, Unidentified Inuit Child, gelatin silver print, LAC, PA-147870.

Catalogue 18. Robert J. Flaherty, Unidentified (Woman) Chesterfield Inlet, gelatin silver bromide print, AGO, 93/280.15.

Figure 17. Robert J. Flaherty, [Unidentified Woman], gelatin silver glass lantern slide, LAC, PA-147870

Catalogue 19. Robert J. Flaherty, Unidentified (Ezechiak), Baffin Island, gelatin silver bromide print, AGO, 93/280.16

Catalogue 20. Robert J. Flaherty, Unidentified (Woman in Hood), Baffin Island, gelatin silver bromide print, $\mathrm{AGO}, 93 / 280.17$

Catalogue 21. Robert J. Flaherty, Sapa? (In Fur Hood), Baffin Island, gelatin silver bromide print, AGO, 93/280.18

Catalogue 22. Robert J. Flaherty, Tooktoo (The Deer), Southern Baffin Island, gelatin silver bromide print, AGO, 93/280.19.....

Catalogue 23. Robert J. Flaherty, Unidentified (Old Man), Baffin Island, AGO, 93/280.20. 
Catalogue 24. Robert J. Flaherty, Eskimo Omiak in the Spring, photogravure, AGO, 92/89.1.

Figure 18. Robert J. Flaherty, Inuit Omiak (boat) in Spring, LAC, gelatin silver print (with tissue overlay), PA-121990

Figure 19. Robert J. Flaherty, Inuit Omiak (boat) in Spring, LAC, gelatin silver print (with tissue overlay), PA-121990 (verso)

Catalogue 25. Robert J. Flaherty, The Walrus Hunter, photogravure, AGO, 92/89.2.

Figure 20. Robert J. Flaherty, The Walrus Hunter from "Nanook of the North", LAC, gelatin silver print, PA-143420

Catalogue 26. Robert J. Flaherty, The Barren Lands, Northern Ungava, photogravure, AGO, 92/89.3

Figure 21. Robert J. Flaherty, [The Barren Lands, Northern Ungava], gelatin silver nitrate negative, LAC, PA-143327.

Catalogue 27. Robert J. Flaherty, Youthful Hunter, photogravure, AGO, 92/89.4

Figure 22. Robert J. Flaherty, Man with Boy (probably Allakariallak/ Nanook and Phillipoosie), gelatin silver print, LAC,

PA-121986 (recto)

Figure 23. Robert J. Flaherty, Man with Boy (probably Allakariallak/ Nanook and Phillipoosie), gelatin silver print, LAC, PA-121986 (verso).

Catalogue 28. Robert J. Flaherty, Abandoned Eskimo Village, photogravure, AGO, 92/89.5.

Figure 24 - Figure 26. Robert J. Flaherty, Two Igloos Built Side by Side and Maybe Partial View of a Third One on the Right: Windows are Seen as Dark Spots, gelatin silver prints, LAC, PA-143435

Figure 27. Robert J. Flaherty, Two Igloos Built Side by Side and Maybe Partial View of a Third One on the Right: Windows are Seen as Dark Spots, gelatin silver prints, LAC, PA-143435. 
Catalogue 29. Robert J. Flaherty, A Labrador Cree (Indian), Northern Labrador, photogravure, AGO, 92/89.7.

Catalogue 30. Robert J. Flaherty, Sapa, Sikoslingmuit Eskimo of Southern Baffin Land, photogravure, AGO, 92/89.9.

Figure 28. Robert J. Flaherty, [Man identified as Sapa], gelatin silver glass plate negative, LAC, PA-500772 ............................66

Figure 29. Robert J. Flaherty, [Man identified as Sapa], gelatin silver print, LAC, PA-500772

Figure 30. Robert J. Flaherty, [Man identified as Sapa], photogravure[?] (on tissue), LAC, PA-500772

Catalogue 31. Robert J. Flaherty, Nascaupie, Indian Chief, Northern Labrador, photogravure, AGO, 92/89.10.

Catalogue 32. Robert J. Flaherty, Canayou (The Sculpin), Sikoslingmuit Eskimo Girl, Southern Baffin Land, photogravure, AGO, 92/89.11

Figure 31. Robert J. Flaherty, [Woman identified as Narlaq], gelatin silver nitrate negative, LAC, PA-500256.

Catalogue 33. Robert J. Flaherty, Nyla and Child, Eteeveemuit Eskimo of Cape Dufferin, Northwestern Ungava, photogravure, AGO, 2007/159.4

Catalogue 34. Robert J. Flaherty, Allegoo (Shining Water), Sikoslingmuit Eskimo Woman, Southern Baffin Land, photogravure, AGO, 2007/159.5

Figure 32. Robert J. Flaherty, Identified as Allegoo (Shining Water) Sikoslingmuit Eskimo Woman, South Baffin Island Eskimo. Other sources identify her as Kanajuk or Kanayuk from the same area, gelatin silver print, LAC, PA-143434

Catalogue 35. Robert J. Flaherty, Summer (August), Eskimo Kayak in Northeastern Hudson Bay, photogravure, AGO, 87/322

Catalogue 36. Robert J. Flaherty, Summer (August), Eskimo Kayak in Northeastern Hudson Bay, photogravure, AGO, 92/89.6 
Catalogue 37. Robert J. Flaherty, The Hunter, Eskimo in the Rough Ice Fields at Sea, photogravure, AGO, 87/323.

Figure 33. Robert J. Flaherty, Still Photo from the Film NANOOK OF THE NORTH Showing the Hunter Probably Nanook/

Allakariallak in the Rough Ice Fields at Sea, gelatin silver print, LAC, PA-143089.

Figure 34. Robert J. Flaherty, Still Photo from the Film NANOOK OF THE NORTH Showing the Hunter Probably Nanook/ Allakariallak in the Rough Ice Fields at Sea, gelatin silver print, LAC, PA-143089 (detail)

Figure 35. Robert J. Flaherty, Still Photo from the Film NANOOK OF THE NORTH Showing the Hunter Probably Nanook/ Allakariallak in the Rough Ice Fields at Sea, gelatin silver print, LAC, PA-143089. .74

Figure 36. Robert J. Flaherty, Still Photo from the Film NANOOK OF THE NORTH Showing the Hunter Probably Nanook/ Allakariallak in the Rough Ice Fields at Sea, gelatin silver print, LAC, PA-143089 (verso)

Catalogue 38. Robert J. Flaherty, The Hunter, Eskimo in the Rough Ice Fields at Sea, photogravure, AGO, 2007/159.3.

Catalogue 39. Robert J. Flaherty, The Huskie (The Wolf Dog of the Eskimos), photogravure, AGO, 87/324

Figure 37. Robert J. Flaherty, [Huskie Dog], gelatin silver print, LAC, PA-113520

Figure 38. Robert J. Flaherty, [Huskie Dog], photogravure[?], LAC, PA-113520.

Catalogue 40. Robert J. Flaherty, The Huskie (The Wolf Dog of the Eskimos), photogravure, AGO, 2007/159.2.

Catalogue 41. Robert J. Flaherty, Tooktoo (The Deer), Chief of Sikoslingmuit Eskimos, Southern Baffin Land, photogravure, AGO, 92/89.8.

Figure 39. Robert J. Flaherty, [Tooktoo (The Deer), Chief of

Sikoslingmuit Eskimos, Southern Baffin Land,] LAC,

Photogravure[?] (on tissue paper), PA-121985 
Catalogue 42. Robert J. Flaherty, Tooktoo (The Deer), Chief of Sikoslingmuit Eskimos, Southern Baffin Land, photogravure, AGO, 2007/159.1....

\section{Unattributed photographs of the North}

Catalogue 43. Unknown photographer, Moose Factory, gelatin silver bromide print, AGO, 93/280.21

Catalogue 44. Robert J. Flaherty (attributed to), Huskies on Ice, Hudson's Bay Area, gelatin silver print, AGO, 93/280.

\section{Portraits of Frances Loring and Florence Wyle}

Catalogue 45. Robert J. Flaherty, Frances Loring, cyanotype, AGO, 86/112 ............83

Catalogue 46. Robert J. Flaherty, Profile of Frances Loring, cyanotype, $\mathrm{AGO}, 86 / 113$

Catalogue 47. Robert J. Flaherty, Frances Loring with shawl, cyanotype, AGO, 86/11

Figure 40. Robert J. Flaherty, Frances Loring 1914-1915, gelatin silver print, AGO, Library \& Archives - Special Collections, Loring and Wyle Fonds, Series 11: photographs, box 15 [no item number]

Catalogue 48. Robert J. Flaherty, Portrait - Frances Loring, toned cyanotype, AGO, 86/115 86

Catalogue 49. Robert J. Flaherty, Portrait of Frances Loring and Florence Wyle, (Church Street, Toronto), toned gelatin silver bromide print, $\mathrm{AGO}, 86 / 116$.

Catalogue 50. Robert J. Flaherty, Portrait of Frances Loring and Florence Wyle, (Church Street, Toronto), cyanotype, AGO, 86/117 .88

Catalogue 51. Robert J. Flaherty, Portrait of Florence Wyle (Church Street, Toronto), toned cyanotype, AGO, 86/114 


\section{Analysis of selected works by Robert J. Flaherty at the AGO}

Figure 41. Robert J. Flaherty, [Man identified as Sapa], gelatin silver bromide print, LAC, PA-500772.

Figure 42. Robert J. Flaherty, [Man identified as Sapa], gelatin silver glass plate negative, LAC, PA-500772 .........................................95

Figure 43. Robert J. Flaherty, Sapa, Sikoslingmuit Eskimo of Southern Baffin Land, AGO, 92/89.9.

Figure 44. Robert J. Flaherty (attributed to), Huskies on Ice, gelatin silver print, AGO, 93/280.22

Figure 45. Robert J. Flaherty, Dog Team Resting in Snow, gelatin silver print, LAC, PA-143511.

Figure 46. Robert J. Flaherty, Frances Loring with Shawl, cyanotype, AGO, 86/111....

Figure 47. Robert J. Flaherty, Frances Loring 1914-1915, gelatin silver print, AGO Library \& Archives - Special Collections, Loring and Wyle fonds, Series 11: photographs, box 15 [no item number]

\section{Appendix A}

Figure 48. Robert J. Flaherty / Revillon Frères, Camera Studies of the Far North colophon page (title leaf), LAC, NLC: E77.5 F53 1922, Amicus No. 10182781 130

Figure 49. Robert J. Flaherty / Revillon Frères, Camera Studies of the Far North colophon page (second leaf), NLC: E77.5 F53 1922, Amicus No. 10182781

Figure 50. Robert J. Flaherty / Revillon Frères, Camera Studies of the Far North colophon page (detail of second leaf), NLC: E77.5 F53 1922, Amicus No. 10182781

Figure 51. Robert J. Flaherty / Revillon Frères, Camera Studies of the Far North colophon page (single leaf), NLC: E77.5 F53 1920z, Amicus No. 10182781 
Figure 52. Robert J. Flaherty / Revillon Frères, Camera Studies of the Far North colophon page (detail of single leaf), NLC: E77.5 F53 1920z, Amicus No. 10182781

Figure 53. Robert J. Flaherty, Canayou (The Sculpin), Sikoslingmuit Eskimo Girl, Southern Baffin Land, photogravure, AGO, 92/89.11....

Figure 54. Robert J. Flaherty, The Gramophone, photogravure, LAC, NLC: E77.5 F53 1922, Amicus No. 10182781

Figure 55. Robert J. Flaherty, Eskimo Fisherman in his Kayak, LAC, NLC: E77.5 F53 1922, Amicus No. 10182781. 136

Figure 56. Robert J. Flaherty, The Harpooner, LAC, NLC: E77.5 F53 1922, Amicus No. 10182781

Figure 57. Robert J. Flaherty, Eskimo Omiak in the Spring, photogravure, AGO, 92/89.1.

Figure 58. Robert J. Flaherty, Abandoned Eskimo Village, photogravure, AGO, 92/89.5.

Figure 59. Robert J. Flaherty, The Barren Lands, Nortehern Ungava, photogravure, AGO, 92/89.3.

Figure 60. Robert J. Flaherty, A Labrador Cree (Indian), Northern Labrador, photogravure, AGO, 92/89.7

Figure 61. Robert J. Flaherty, Sapa, Sikoslingmuit Eskimo of Southern Baffin Land, photogravure, AGO, 92/89.9

Figure 62. Robert J. Flaherty, Nascaupie, Indian Chief, Northern Labrador, photogravure, AGO, 92/89.10

Figure 63, Robert J. Flaherty, Youthful Hunter, photogravure, AGO, 92/89.4......140

Figure 64. Robert J. Flaherty, The Walrus Hunter, photogravure, AGO, 92/89.2 ...140

Figure 65. Robert J. Flaherty, Summer (August), Eskimo Kayak in Northeastern Hudson Bay, photogravure, AGO, 92/89.6 (and 87/322)..141 
Figure 66. Robert J. Flaherty, Nyla and Child, Eteeveemuit Eskimo of Cape Dufferin, Northwestern Ungava, photogravure, AGO, 2007/159.4......141

Figure 67. Robert J. Flaherty, The Huskie (The Wolf Dog of the Eskimos), photogravure, AGO, 87/324 (and 2007/159.2)

Figure 68. Robert J. Flaherty, Tooktoo (The Deer), Chief of Sikoslingmuit Eskimos, Southern Baffin Land, photogravure, AGO, 92/89.8 (and 2007/159.1)

Figure 69. Robert J. Flaherty, Allegoo (Shining Water), Sikoslingmuit Eskimo Woman, Southern Baffin Land, photogravure, AGO, 2007/159.5 ........143

Figure 70. Robert J. Flaherty, The Hunter, Eskimo in the Rough Ice Fields at Sea, photogravure, AGO, 87/323 (and 2007/159.3). 


\section{Introduction}

Robert J. Flaherty (1884-1951) traveled to Canada's Hudson Bay Arctic region on four trips between 1910 and 1916, and again from 1920 to $1921 .^{1}$ The first four expeditions, which began in 1910, were commissioned by Sir William Mackenzie (18491923) to look for iron ore deposits. The trip in 1921 was financed by the fur trading company Revillon Frères to make a film about the life of the inhabitants. From the first expedition to the north, Flaherty employed photography as a tool not only for documenting geological information, but also for photographing aspects of the environment, such as the arctic landscapes, animals and the Inuit, who also worked as his assistants. ${ }^{2}$ In 1922, the film Nanook of the North was released and photographs taken by Flaherty over the course of his trips were reproduced as photogravures, published and sold in portfolios titled Camera Studies of the Far North, to promote the film. ${ }^{3}$

The Art Gallery of Ontario (AGO) has fifty-one photographic works by Flaherty in its collection. These include forty-four works taken in the north; twenty-three gelatin silver photographs, nineteen photogravures (two of them bear the same image as the gelatin silver prints) and two gelatin silver photographs whose maker is unknown, but that are associated with the Flaherty collection at AGO. Flaherty also took portraits of the Canadian sculptors Frances Loring (1887-1968) and Florence Wyle (1881-1968) in Toronto, which comprise six cyanotypes and one gelatin silver photograph in the collection. Together, they form a relatively small but representative group of vintage

\footnotetext{
${ }^{1}$ Robert J. Flaherty, "The Belcher Islands of Hudson Bay: Their Discoveries and Exploration," Geographical Review. Vol. 5, No. 6 (June 1918): 433-458. American Geographical Society. http://www.jstor.org/stable/207804 (accessed October 13, 2009).

2 Jo-Anne Birnie Danzker, Robert Flaherty: Photographer / Filmmaker (The Imuit 1910-1922) (Vancouver: Vancouver Art Gallery, 1979), 3, 27.

${ }^{3}$ Ibid, 24.
} 
photographs - one that contains gelatin silver photographs that were produced under extreme sub-Arctic climate; photogravures that were produced for turning a profit as a result of the film, Nanook of the North, and the cyanotype portraits of Loring and Wyle, which are very different from the photographs Flaherty took of the Inuit.

This thesis is a practical project that provides a complete, fully illustrated catalogue of the Flaherty photographs and photogravures at AGO. The main objectives of the catalogue are to verify and expand upon existing information in the cataloguing records at AGO and make this collection more accessible to AGO curatorial staff and outside researchers. In addition to the revised cataloguing, I have selected three objects from the Flaherty collection to provide an in-depth study of his photographic style and production method. It is anticipated that further scholarship on Flaherty will continue to extend our knowledge of his work, and that the analysis here provides an example of how it can be done, based on the information in this catalogue.

For my research, the principal place visited was the Library and Archives of Canada (LAC) in Ottawa. At LAC, Flaherty's related negatives and photographs to his works at AGO were examined and visually documented. The related objects have been included in the catalogue. ${ }^{4}$

This thesis includes an essay and a catalogue. The essay includes a summary biography on Flaherty; a literature review of what is presently known about Flaherty and his photography; a brief description of Flaherty's photographs in public institutions, and an analysis of three photographs from AGO collection, primarily based on the catalogue.

\footnotetext{
${ }^{4}$ The bulk of the Flaherty Collection at LAC is on loan from the Robert and Frances Flaherty Study Centre, School of Theology, Claremont University, Claremont, California. However, LAC does own several works by Flaherty, principally the photogravure portfolio, Camera Studies of the Far North, which were also examined and documented during this trip.
} 
The analysis, is divided into four sub-sections: Photographing the north from 1910-1916 and 1921-1922, photographs of northern scenes and portraits of the Inuit, the unknown photographs (related to the north) and portraits of Loring and Wyle.

The catalogue is the largest section in the thesis. It is prefaced by an introduction with each field defined. The catalogue proper contains fifty-one records and illustrations. Lastly, there are two appendices, the illustrated set of eighteen photogravures published in the portfolio Camera Studies of the North, and a list of works in the Flaherty collection at the AGO that were originally donated in an album. This is followed by the bibliography. 


\section{Methodology and Research Process}

\section{Methodology}

At the outset of the project, the fifty-one cataloguing records in AGO's electronic database, TMS, were examined and I found that some of the information was either missing or incomplete and that all the information needed to be verified. When the works were acquired, their respective donors provided what information they knew. ${ }^{s}$ For the AGO exhibition, "Robert Flaherty: Camera Studies" 15 June - 18 September 1994, research was carried out in 1994 by Maia-Mari Sutnik, now Curator of Photography, and Janet Dewan, an independent researcher. Dewan conducted research at LAC and brought $4 \times 6$ inch photographs of Flaherty's work with her. On the verso of each photograph, she inscribed the date and location of when and where the original Flaherty photograph might have been taken. The file containing Dewan's research includes photographic documentation of Flaherty's photographs, list of the works, and the 1994 exhibition labels on transparency material. ${ }^{6}$ Judging by the existing Flaherty records in the AGO database, the research by Dewan resulted in changes in the dating and titling of the photographs from their original descriptive titles and dates created by the cataloguer at AGO. I have retained the information derived from Dewan's research wherever possible, and a note to indicate what was previously written follows any alterations to the title or date.

\footnotetext{
${ }^{5}$ There were five acquisitions for the Flaherty works, donated by the Estates of Frances Loring and Florence Wyle (1983); Sandra Ball and Marcia Reid (1987); Susan Osborn (1992); Gordon M. Robb (1993) and an anonymous donor (2007). Out of these donors, only the provenance of Robb's collection could be traced back to Flaherty himself, who had given his photographs to Robb's grandmother. Titles of all the works were created by AGO, except for the photogravures, some of which had titles imprinted on them.

${ }^{6}$ The filename is "FLAHERTY, Robert J./ Research File: Photographs \& Photogravures (Gifts to AGO)" is kept by Maia-Mari Sutnik, Curator of Photography, AGO.
} 
The first step in developing the catalogue was to determine which of the fields had information that was relevant to the new catalogue; second, what details were missing; and third, if any of the information needed to be moved to a different field. Each field and element was carefully considered. The actual objects were also physically examined for inscriptions and qualitative information, such as the appearance of the images.

Three sources were consulted to research and establish the overall structure and the individual fields for the catalogue portion: Janet Dewan's The Photographs of Linnaeus Tripe: A Catalogue Raisonné (2005); Mira Godard Study Centre (MGSC), Ryerson University, Print Collection Cataloguing Manual (2001) developed by David Harris; and The Museum System (TMS) database (2009 version). These different types of cataloguing methods, all of which were developed in the twenty-first century, provide a systematic model for creating a descriptive record of a photographic object. Due to the scope of this thesis, which focuses on the catalogue of fifty-one objects rather than cataloguing methods, I did not research beyond the methods of Dewan, Harris or TMS.

The information in Dewan's catalogue raisonné of the work of Linneaus Tripe that I found most useful for application to this thesis were: the reproduction of the photographs in the catalogue; information about the negative which included the photographic process, size, location and inscriptions on the recto and/or verso, exhibition history of the print, and notes in which additional information about the print are included. Additionally, the appendices of exhibitions and provenance notes elucidated further information about where the photographs were exhibited and the history of their owners and collectors. 
Harris' cataloguing manual was developed in 2001 , and was specifically designed to catalogue photographic objects in Filemaker Pro database software used by the MGSC. As outlined in the cataloguing portion of the manual, there are twelve required fields where information must be entered and sixteen optional fields that can be included as the information becomes available. Together, the twenty-eight fields represent a full cataloguing record. In comparing these fields with data fields found in TMS - the system presently used by the AGO - there are many similarities between the two. However, as the AGO does not have a cataloguing manual at this time, the cataloguing manual developed by Harris provided detailed procedures on how to enter each field consistently and systematically. Lastly, TMS database is proprietary software that is being gradually implemented at AGO that began in 2009.

The goal was to create a set of fields that were either the same or similar to TMS, so that information from the catalogue in this thesis can be easily transferred electronically into AGO's database system. However, the catalogue also functions as a stand-alone reference for outside researchers. In the end, fourteen fields were created for the photographs and sixteen for the photogravures. (These are described in the introduction to the catalogue).

\section{Research Process}

The Flaherty works are stored in the Prints and Drawing vault located in the Marvin Gelber Print and Drawing Study Centre on the main floor of AGO. Each photograph has been matted with a tissue overlay to protect it from dust and debris, and is 
stored in a Solander box. As a student at AGO from September 2009 - July 2010, I had privileges to access the vault on my own.

The photographs and photogravures were remeasured and checked for inscriptions or anything adhered to the verso. Fortunately, for illustrations in the catalogue, most of the Flaherty works had already been photographed by AGO. Jane Rhodes at the Image Resource Centre, AGO, provided me with low-resolution digital copies of the work. The process of finding the Flaherty negatives that matched the photographs at AGO, started in February 2010 when I contacted Dr. Jack Coogan at the Robert and Frances Flaherty Study Center, School of Theology, Claremont University in Claremont, California. Both Birnie Danzker's and Christopher's publications indicated that Flaherty's collection of photographs and negatives were deposited in Claremont. Coogan informed me that majority of the photographic material was on loan to the Library and Archives of Canada in Ottawa. The Study Center in Claremont had only the Visual Indexes of Flaherty's photographic material and a few copy prints. These indexes, six in total, were sent to me as a URL link in PDF format. In these indexes, each page resembles a contact sheet, displaying thirty-five images per page. ${ }^{7}$ Each frame has an item number beginning with " $N$ ". I was able to use them to find the image that matched the ones at AGO.

Meanwhile, in the same month, I contacted Joanne Guillemette, Archivist at LAC, to discuss the Flaherty material and to arrange for a research trip. My goal was to examine every object that was related to the fifty-one objects at AGO. Before my visit, I

\footnotetext{
${ }^{7}$ From the Visual Index it is not clear whether the images are photographs, photogravures or negatives.

8 Jo-Anne Birnie Danzker explained that the Claremont material is divided into four groups (N (Nanook) 1-383 and N 2001-2822; C 1-148 (Canada); G (Geology) 1-55; and OL (On the Laddie) 1-153. See, "Robert Flaherty/ Photographer" Studies in Visual Communication, vol. 6, no. 2 (Summer 1980), 6.
} 
prepared a document with all of the item-numbers for Guillemette to retrieve. As some of the materials were nitrate and glass plate negatives, the document had to be sent three weeks in advance of my visit to allow Guillemette enough time to retrieve them from an off-site storage facility. Each item is detailed with their item-level accession numbers with their title names, extent of the materials, and corresponding number in the Visual Indexes. There were twelve objects that could not be found in the visual indexes, and therefore, could not be searched on LAC's website; I sent Guillemette images of these in advance.

I made my research trip to LAC in April 2010. When I arrived at the Preservation Centre (Archives) in Gatineau, Quebec, some of the items that I requested could not be found, despite their having an accession number and listing on the LAC's website. Fortunately, Guillemette had been able to locate four of the twelve images, not included in the Visual Indexes. For all of the works that were available, I measured and photographed them (recto and verso), as well as made notes of inscriptions or marks. I entered all the information in the same spreadsheet I had prepared for Guillemette.

At the end of the research trip, five glass plate negatives were found to be related to the AGO Flaherty prints along with several other photographic objects including lantern slides, nitrate negatives, and gelatin silver photographs. I was also able to confirm that there were eighteen photogravures published for the portfolio, Camera Studies of the Far North. Additionally, one of the photographs related to the photogravure, The Hunter: Eskimo may have been printed from a film still from Nanook. ${ }^{9}$

\footnotetext{
${ }^{9}$ Catalogue 37 (AGO 87/323) - see under "Related object(s) at LAC".
} 
In April 2010, I contacted R. Scott James, Archivist at The Arts and Letters Club of Toronto to find information on Flaherty's exhibition and screening of the Baffin Island film in 1915 (precursor to Nanook, 1920-21). James confirmed Flaherty's membership at the Club from 1914 to 1917, but could not find any documentation that Flaherty held an exhibition there. His screenings included a lecture presentation and showed lantern slides. ${ }^{10}$

For the Loring and Wyle portraits, I contacted Amy Furness, Archivist, Special Collections, E.P Taylor Research Library and Archives at the AGO, to see the Frances Loring and Florence Wyle fonds. The Estate of Frances Loring and Florence Wyle had donated a large number of photographs to Special Collections in 1983. A related photograph of Loring was found in one of the oversized boxes.

To further verify the objects' provenance, exhibition history and image reproduction history, lastly the registration files at $\mathrm{AGO}$ were reviewed. ${ }^{11}$

${ }^{10}$ Flaherty's screening included a lecture presentation and showed lantern slides. Robert Christopher, Robert and Frances Flaherty: A Documentary Life, 1883-1922 (Kingston and Montreal: McGill-Queen's University Press, 2005), 210.

11 The author was given access to the registration files due to her status as a student at AGO from September 2009 - July 2010. 


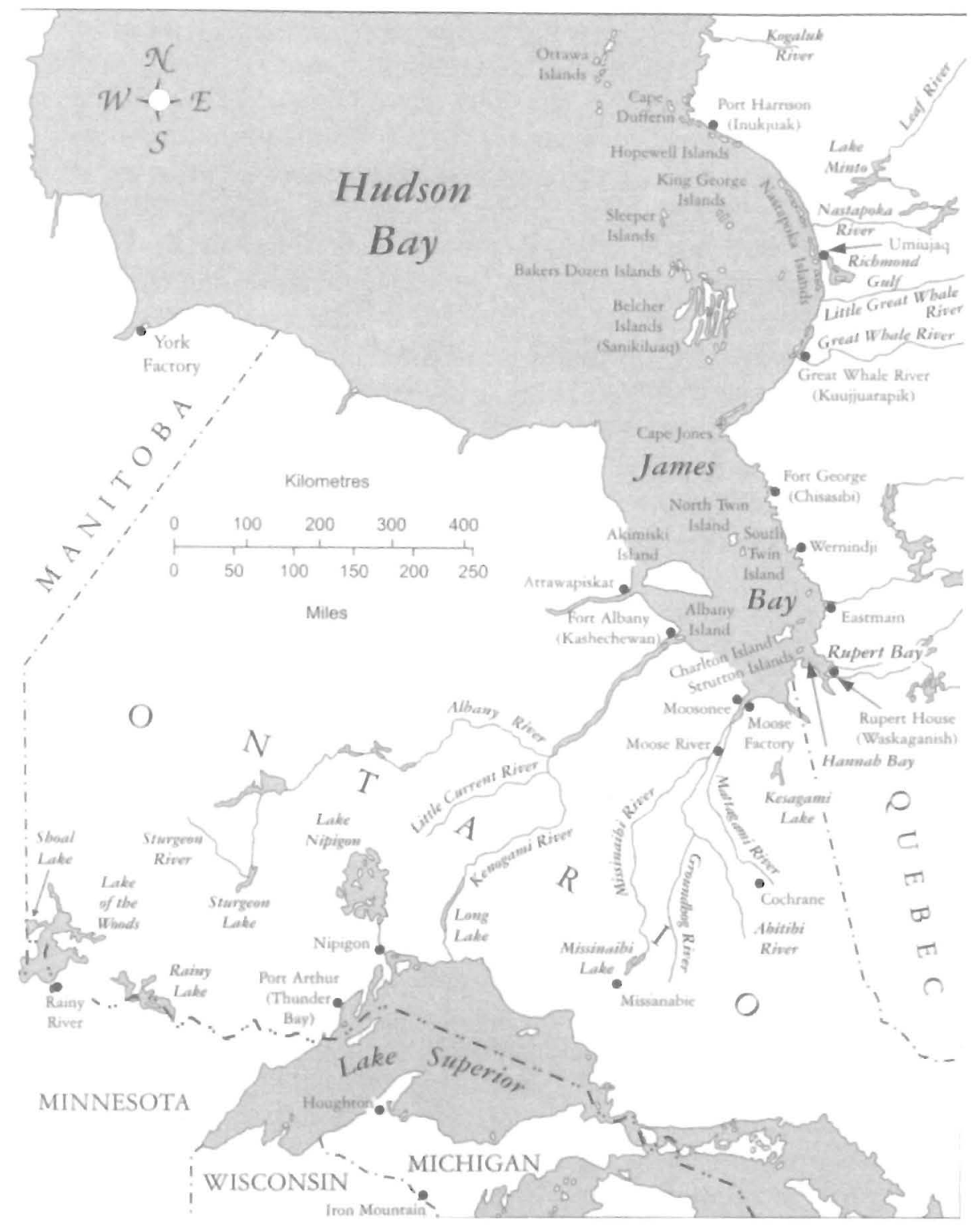

Northern Ontario and the Southern Hudson Bay Region, where Flaherty travelled for his first two cxpeditions, 1910-12 12

12 Illustration and map reproduced from Robert Christopher, Robert and Frances Flaherty, between pages $\mathrm{xxi}$ and 5 . 


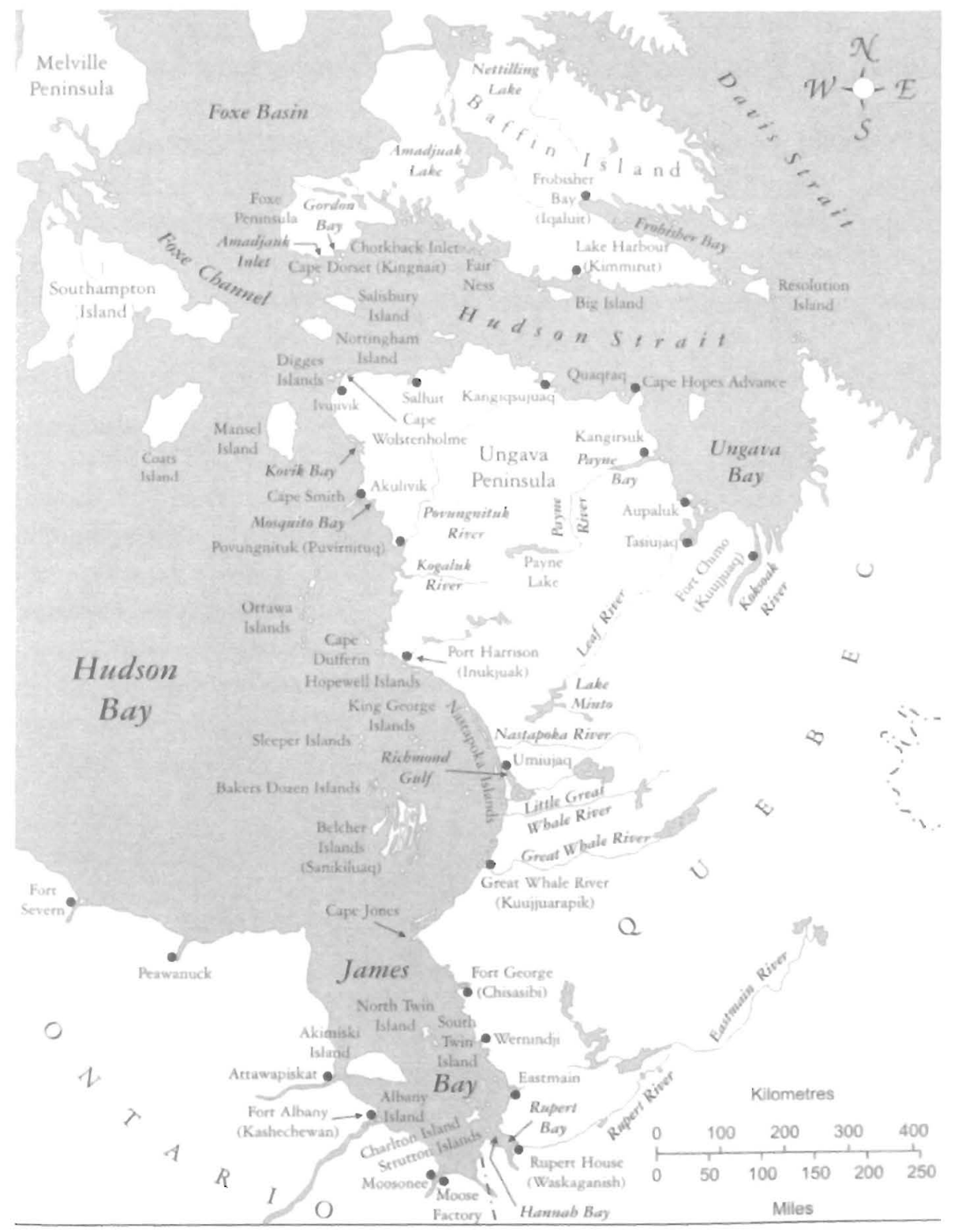

The Hudson Bay and Baffin Island area, where Flaherty travelled to for his third and fourth expeditions, 1913-16 ${ }^{13}$

13 Ibid, between pages xxi and 5 . 


\section{Biography of Robert J. Flaherty}

Robert Joseph Flaherty was born in Iron Mountain, Michigan on February 16, 1884. His parents, Robert Henry Flaherty (1856-1923) and Susan Klöckner (1858-1924) were of Irish Protestant and German Catholic descent, respectively. Flaherty’s father was an owner and manager of a mine in Iron Mountain, but the economic recession in the United States in the late 1890s forced the mine to close, thereby forcing the Flahertys' to relocate to Port Arthur (now Thunder Bay), Ontario in 1901. Flaherty followed in his father's footsteps in becoming a surveyor and a geological explorer. His formal education included Toronto's Upper Canada College, followed later by a short tenure of seven months at the Michigan College of Mines, where biographer Arthur Calder-Marshall later stated "the college authorities, recognizing that he [Flaherty] had none of the qualities of an academic mineralogist, told him not to waste his time and theirs." the early biographies (including those of Griffith, Calder-Marshall and Barsam) written about Flaherty, where he is portrayed as a "cigar-smoking Huck Finn."15 This image of Flaherty perpetuates what was to become a widely held idea of him as a natural born rebel who later in life became a pioneering filmmaker. Helen Van Dongen, Flaherty's film editor for The Land (1942) and co-producer of Louisiana Story (1948) presents another view of Flaherty's character; he was a great storyteller and often lent himself to exaggerations about his life. Van Dongen claims that Flaherty's films were not documentaries despite John Grierson's label on Flaherty as the "father of documentary".

\footnotetext{
${ }^{14}$ Arthur, Calder-Marshall, The Innocent Eye: The Life of Robert J. Flaherty. (New York: Harcourt, Brace \& World, 1963), 20.

15 Robert J. Christopher, Robert and Frances Flaherty: A Documentary Life, 1883-1922 (Kingston and Montreal: McGill-Queen's University Press, 2005), 24.
} 
Flaherty's films were based on fictional storylines and the facts were "interpreted and adapted by him and molded into elements of a world created by him, a world entirely his own, in which he firmly believed."16

In 1910, Flaherty's father introduced him to Sir William Mackenzie, President of the Canadian Northern Railway, who commissioned Flaherty to look for iron ore deposits on the Nastapoka Islands off the east coast of Hudson Bay in Northern Quebec. ${ }^{17}$ This was the first of four expeditions financed by Mackenzie that brought Flaherty to the Arctic: 5 August 1910 - 14 March 1911; 6 June 1911 - 8 August 1912; 15 June $1913-3$ October 1914, and 11 August 1915 - 21 September 1916. His final trip was to Port Harrison (Inukjuak), Quebec from 1920-1921, where he filmed Nanook of the North. ${ }^{18}$ This last trip was financed by the fur trading company Revillon Frères on the terms that Flaherty would produce two films; one to focus on "the natural Eskimo way of living in the wilds" and the second to feature the Revillon Frères trading post in Port Harrison. ${ }^{19}$ During the time he spent in the north, before he filmed Nanook, Flaherty honed his skills as a geological prospector and proved to Mackenzie that he was capable of traveling in the extreme climates of the Arctic, eventhough he did receive a great deal of assistance from the Inuit, whose navigation and survival skills were indispensable to his surveying. ${ }^{20}$ One of Flaherty's key accomplishments occurred during his third expedition, where he "re-discovered" the Belcher Islands. Flaherty subsequently wrote two articles

\footnotetext{
${ }^{16}$ Helen van Dongen, "Robert J. Flaherty 1884-1951," Film Quarterly. Vol. 18, No.4 (Summer, 1965): 34. University of Califomia Press. http://www.jstor.org/stable/1210252 (accessed August 16, 2010).

17 Jo-Anne Birnie Danzker, Robert Flaherty: Photographer / Filmmaker, 17.

18 . See page $x$ and $x i$ in this thesis for maps of Flaherty's first four expeditions, reproduced from Robert Christopher, Robert and Frances Flaherty, between pages xxi and 5.

19 Ibid, 326.

${ }^{20}$ Flaherty gives recognition to his Inuit aids in "The Belcher Islands of Hudson Bay: Their Discoveries and Exploration," Geographical Review. Vol. 5, No. 6 (June 1918): 456. American Geographical Society. http://www.jstor.org/stable/207804 (accessed October 13, 2009).
} 
for the Geographical Review in 1918; one of them was on the discovery of the Belcher Islands and included his photographs of the landscape and portraits of the Inuit taken during the three initial expeditions from $1910-1914 .^{21}$

Flaherty had a strong interest in photography. According to his sister Frances, Flaherty was an avid photographer from an early age, and she said that he preferred the "older style plate camera with tripod" to the Kodak "snapshot" cameras. ${ }^{22}$ It is unsurprising that Flaherty elected to bring $4 \times 5$ inch plate cameras on all of his expeditions to the north. In his diaries, starting from the first expedition in 1910, Flaherty documented when and what he photographed.

For the third expedition (1913-1914), Flaherty brought along a Bell \& Howell motion-picture camera, as suggested by Mackenzie. ${ }^{23}$ Prior to this trip, Flaherty took a three-week course in Rochester, New York, to learn how to use it and, shortly after, bought a portable developing and printing machine for use in the Arctic. ${ }^{24}$ Flaherty was elected to the Royal Geographical Society on May 5, 1913 for his explorations to the "highest northern latitude" in Ungava Peninsula, the first white man to accomplish this feat. The recognition allowed him to include the initials F.R.G.S. (Fellow of the Royal Geographical Society) to his name in subsequent publications. However, in 1940, he was dismissed by the Society for not paying his dues. ${ }^{25}$ The same problem had occurred earlier with the Arts and Letters Club of Toronto, where Flaherty became a member in

\footnotetext{
21 Robert J. Flaherty, "The Belcher Islands of Hudson Bay: Their Discoveries and Exploration," Geographical Review. Vol. 5, No. 6 (June 1918): 433-458. American Geographical Society. http://www.jstor.org/stable/207804 (accessed October 13, 2009).

22 Robert Christopher, Robert and Frances Flaherty, 25.

23 This claim however has been disputed by Christopher in Robert and Frances Flaherty, 131.

24 Arthur Calder-Marshall, The Innocent Eye, 55.

25 Ibid, 128.
} 
February 1913, but was subsequently removed in 1917 for not paying his fees. ${ }^{26}$ His membership record indicates that he was in Toronto just before his third expedition in 1913, which he left for in June. Shortly after his return in October 1914, he brought his then-fiancée Frances Hubbard (1885-1972) to the Club, where she met Frances Loring. ${ }^{27}$

On November 12, 1914, Robert Flaherty married Hubbard after a ten-year engagement. They had met in Painesdale, Michigan where Flaherty was employed by Hubbard's father, Dr. Lucius L. Hubbard (1849-1933) at the Copper Range Mining Company to perform odd jobs. ${ }^{28}$ Dr. Hubbard took his daughter on surveying trips and as it turned out, she and Flaherty had a common desire for traveling "in the wild and of seeing country which hadn't been [seen] before..."29 which cemented their bond early on. During their marriage and the rearing of their three children, Hubbard contributed greatly to Flaherty's career as a filmmaker, eventhough her work as a writer and photographer was largely overshadowed by her husband's accomplishments. ${ }^{30}$

After the release of Nanook in 1922, Flaherty went on to direct (and in some cases, co-direct) The Potterymaker (1925), Moana: A Romance of the Golden Age (1926), Twenty-Four Dollar Island (1927), Tabu: The Story of the South Seas (1931), Industrial Britain (1933), Man of Aran (1934), Elephant Boy (1937), The Land (1942), Louisiana Story (1948), Guernica (1949), and The Titan: The Story of Michelangelo (1949). ${ }^{31}$ Shortly before his death, he received an honourary degree of Doctor of Fine

\footnotetext{
${ }^{26}$ Arts and Letters Club of Toronto, "Robert Flaherty" card catalogue.

27 Robert Christopher, Robert and Frances Flaherty, 225, 256.

28 Robert Christopher, Robert and Frances Flaherty, 42.

${ }^{29}$ Arthur Calder-Marshall, The Innocent Eye, 20.

${ }^{30}$ Robert Christopher, Robert and Frances Flaherty, xvi. It is worth mentioning that Frances Flaherty took a considerable group of photographs while filming Moana in Samoa.

${ }^{31}$ William T. Murphy, Robert Flaherty: A Guide to References and Resources (Boston, Massachusetts: G.K. Hall \& Co., 1978), 97-110.
} 
Arts from the University of Michigan in 1950 for his work as a filmmaker. Flaherty passed away on July 23, 1951 at his home in Dummerston, Vermont.

Despite the lack of recognition of Flaherty's Arctic photographs during his lifetime, the Inuit portraits, which have survived, are considered historical documents as well as artworks in their own right. The photogravures, which were produced for Nanook, are found in many institutional collections. Today, Flaherty is a celebrated filmmaker in the documentary genre, ${ }^{32}$ but is increasingly being recognized as an accomplished photographer for his images of the Inuit and landscapes of Northern Arctic in Canada. ${ }^{33}$

32 The term "documentary" was first used in reference to Flaherty's second film Moana by the Scottish filmmaker, John Grierson. See Christopher, Robert and Frances Flaherty, 384.

33 Flaherty's Inuit photographs were one of the subjects discussed in André Gunthert and Michel Poivert's L'Art de la Photographie des Origines à nos Jours (Paris: Editions Citadelles-Mazenod, 2007), 371-373. 


\section{Literature Review}

This literature review is divided into two sections: the first discusses the literature around two bodies of Flaherty's work, namely his photographs and photogravures related to northern scenes and portraits and the second discusses his photographs of Frances Loring and Florence Wyle. The literature on Flaherty is extensive; it includes biographies, critical essays, and film reviews that pertain to his life and largely his filmmaking career. ${ }^{34}$ For the purpose of this survey, only the body of literature written about Flaherty and Nanook of the North, as well as his relationship with Loring and Wyle is examined.

Early biographies on Flaherty describe his upbringing as a boisterous young man who found his calling as a filmmaker during the Northern expeditions from 1910-1916, culminating in the film Nanook of the North, which marked the beginning of his filming career. This story is chronicled in Richard Griffith's The World of Robert Flaherty (1953); Arthur Calder-Marshall's The Innocent Eye: The Life of Robert J. Flaherty (1963) and Richard Barsam's The Vision of Robert Flaherty: The Artist as Myth and Filmmaker (1988). Photographs taken by Flaherty during his trips to the north are briefly discussed in The Innocent Eye, which was based on the research and unpublished manuscript by Paul Rotha and Basil Wright completed in $1959 .{ }^{35}$ In a letter that Mrs. Evelyn Lyon Fellowes wrote to Rotha, she recalled chaperoning her friend Miss Olive Caven and Flaherty on a date in Toronto in 1914; both she and Miss Caven received photographs from Flaherty.

\footnotetext{
34 William Murphy, Robert Flaherty, 113-151.

35 Robert Christopher, Robert and Frances Flaherty, xv. Also, Rotha and Wright's essay, "Nanook in the North" is reprinted in Studies in Visual Communication, vol.6, no.2 (Summer 1980), 33-60 is excerpted from Rotha's and Wright's Robert Flaherty: A Biography (Philadelphia: University of Pennsylvania Press, 1983).
} 
"I chaperoned them once at the old Queen's Hotel (now demolished). On this occasion he gave me a wonderful photo of a busky dog, taken I understand in an igloo, he gave Miss Caven many beautiful presents including a white fox fur, and numerous photos of Eskimoes which she accepted as she admired him very much., ${ }^{, 36}$

This quotation points to the fact that a number of Flaherty's Inuit portraits were made either before or during his third expedition (1913-1914), and that, on his return, he gave the Inuit portraits to his acquaintances in Toronto. Calder-Marshall's biography also mentions that Flaherty's Graflex still camera was repaired by one of his Inuit assistants, "Harry Lauder". ${ }^{37}$ Additionally, Revillon Frères, whose name appears on Flaherty's photogravure prints as the copyright holder, is mentioned as the French fur-trading company that financed the production of Nanook. ${ }^{38}$ However, none of the biographies acknowledged Flaherty as a photographer nor discuss the photographs and the photogravures used to promote Nanook until Robert J. Christopher's 2005 Robert and Frances Flaherty: A Documentary Life, 1883-1922, which will be discussed later in this survey.

The subject of Flaherty's film, Nanook, has generated much discussion within the literature of ethnographic studies and film criticism. However, this thesis will not be addressing any ethnographic aspects of the subjects that appear in the photographs, photogravures nor the film Nanook, although these aspects and the relationship between

\footnotetext{
${ }^{36}$ Arthur Calder-Marshall, The Innocent Eye, 62; Birnie Danzker, Robert Flaherty, Photographer / Filmmaker, 19.

37 Ibid, 84.

${ }^{38}$ Richard Barsam, The Vision of Robert Flaherty: The Artist as Myth and Filmmaker. (Bloomington and Indianapolis: Indiana University Press, 1988), 16.
} 
the photogravures and the film would be essential to a complete study of Flaherty's photography. ${ }^{39}$

The articles and essays that Flaherty published in 1918 and 1922-1924 contain illustrations of his trips to the north, but neither the photographs nor his photographic production were discussed by Flaherty in any of his writings. ${ }^{40}$ Flaherty's only mention of photographing is in My Eskimo Friends (1924) in which he briefly describes taking close-up photographs of rock samples. ${ }^{41}$

Jo-Anne Birnie Danzker's seminal 1979 exhibition catalogue, Robert FlahertyPhotographer/Filmmaker (The Inuit 1910-1922), is still an invaluable source on Flaherty as a photographer. It was the first comprehensive study based on original research on Flaherty's photographs of the Inuit. ${ }^{42}$ The catalogue contains entries from the Flahertys' diaries, a chronology outlining his northern expeditions, and most importantly a catalogue of his Inuit portraits- of which approximately a hundred were exhibited at the Vancouver Art Gallery (1 December 1979 to January 13 1980) and the International Centre of Photography in New York (4 April to May 18 1980) and twenty-nine were

\footnotetext{
${ }^{39}$ The photograph, Still Photo from the Film NANOOK OF THE NORTH Showing the Hunter...(figure 40 in catalogue 37) indicates that the image was taken from the film. Further aspects of the relationship between the film and still photographs would be a subject for further exploration. Two sources were consulted, the issue of Studies in Visual Communication, vol. 6, no. 2 (Summer 1980), which is largely devoted to Flarherty and the north, and Jay Ruby's "The Aggie Must Come First: Robert Flaherty's Place in Ethnographic Film History" Picturing Culture: Explorations of Film and Anthropology (Chicago: University of Chicago Press, 2000), but these did not provide any relevant information on the discussion of the film's narrative and the photogravure images.

${ }^{40}$ Robert J. Flaherty, "The Belchers Islands of Husdson Bay", The Geographical Review, vol. V, no. 6, June, 1918; "Two Traverses Across Ungava Peninsula, Labrador", The Geographical Review, vol. VI, no.2, 1918; "How I Filmed Nanook of the North", The World's Work, September 1922; "Life Among the Eskimos", The World's Work, October 1922; "Wetalltook's Islands", The World's Work, February, 1923; "Winter on Wetallook's Islands", The World's Work, March, 1923.

${ }^{41}$ Robert J. Flaherty in collaboration with Frances Hubbard Flaherty, My Eskimo Friends (Garden City and New York: Doubleday, Page \& Company, 1924), 17.

42 Portions of the exhibition catalogue including the illustrations are reprinted in Studies in Visual Communication, vol. 6, no. 2 (Summer 1980), 5-32.
} 
eproduced in the catalogue. ${ }^{43}$ Birnie Danzker does not discuss the photographic processes of the prints nor their pictorialist qualities. Instead, the portraits of the Inuit are described as "studio-types" and "confrontation" portraits. She also mentions exhibitions of Flaherty's photographs at The Arts and Letters Club in Toronto (January 3, 1915) and Convocation Hall, University of Toronto (March 30, 1915). ${ }^{44}$ In the catalogue itself, most of the entries contain a "note" field, which provides information on the identity of the subject, a possible date, and institutions that have the photograph. Moreover, the exhibition catalogue published an important diary excerpt of Frances Flaherty from April 1915, when she and Flaherty met Edward Curtis in New York. During this meeting Curtis showed them his photogravure portfolio of the North American Indian (an ongoing project of Curtis at the time); his portfolios were sold in sets, which may have planted the idea for the Flahertys to do the same with their photographs of the Inuit. ${ }^{45}$ Later that month, the Flahertys also visited Alfred Stieglitz at 291, his gallery in New York, where Flaherty showed his portraits of the Inuit to Steiglitz, and the Flahertys left with his words of encouragement and autographed copies of Camera Work. $^{46}$

Robert J. Christopher's essay, "Through Canada's Northland: The Arctic Photography of Robert J. Flaherty" (1998) discusses Flaherty's album of a hundred and two photographs he made and deposited in the British Library in May 1911, and that had been rediscovered in 1998. Christopher explores Flaherty's interest and practice in photography before and during his first expedition to the North. Additionally, he

\footnotetext{
43 The twenty-nine Inuit portraits reproduced in the catalogue do not include the other images taken by Flaherty of northern inhabitants.

44 Jo-Anne Birnie Danzker, Robert Flaherty, 26. Also, Frances' diary entry for January 7, 1915 wrote about the costs printing and framing of photographs, which might indicate that the photographs were framed for the two exhibitions (Christopher, Robert and Frances Flaherty, 231.)

45 Ibid, 26.

${ }^{46} \mathrm{Ibid}, 26$. I also discuss these visits in Chapter 4 of this thesis.
} 
analyzes the gaze and facial expressions of Flaherty's early photographs of the Inuit that were taken in Great Whale River in 1910-1911. This essay provides an examination of Flaherty's early photographic production and aesthetic in the 1911 album, as the album itself is important in dating and understanding Flaherty's early work. ${ }^{47}$

Christopher's full-length biography Robert and Frances Flaherty: $A$ Documentary Life, 1883-1922 (2005) centres on the years before and during the making of Nanook, and draws extensively on the Flahertys' diaries (Robert and Frances kept separate diaries), which are deposited at the Butler Library, Columbia University. ${ }^{48}$ In the book's introduction, Christopher states that Flaherty was both a photographer and a filmmaker and provides considerable documentation of his photographic activity. For example, Robert Flaherty's diary entry for March 6, 1912 reads:

Still thick, snowing with northwest wind. Outfit as follows: Flour, beans, bacon, Pork dried fruit, desiccated potatoes, tea, sugar for the three men for five weeks. Presents of tobacco, matches, mouth organs, knives, needles, fishhooks, and Candy to the Eskimo. Two Cameras, $5 \times 4$ Eastman plate, and $4 \times 5$ Graflex with 200 exposures. ${ }^{49}$

It should be noted that this particular entry was not included in the previous biographies and this emphasizes the fact that Flaherty's photography becomes a feature only in Christopher's biography. Christopher also provides entries that describe, for example in 1913, how Flaherty took portraits of the Inuit by setting up a small studio tent near the house for taking portraits of the Inuit. ${ }^{50}$ Christopher briefly discusses Flaherty"s "studio-

\footnotetext{
${ }^{47}$ Robert Christopher, Robert and Frances Flaherty, 70.

${ }^{48}$ Regrettably, I was unable to consult the Flaherty diaries in person. Perhaps it would be a future research project, to systematically go through the diaries and determine how many times Flaherty mentioned photographing against the number of photographs he produced during that period, 1910-1921.

${ }^{49}$ Robert Christopher, Robert and Frances Flaherty, 91.

50 Ibid, 150.
} 
type" photographs which "reveal Flaherty reaching for a more pictorial style, a style that uses side lighting and softer focus to portray a more evocative personality in his sitters."

A photograph of Frances Loring and Florence Wyle is briefly mentioned in Elspeth Cameron's And Beauty Answers (2007), ${ }^{52}$ and Flaherty's portrait of the women in the AGO collection is reproduced on the cover of the publication. Loring and Wyle's friendships with Flaherty are also discussed in the two biographies of the sculptresses. ${ }^{53}$ Interestingly, Cameron claims that one of Loring's sculptures, Eskimo Mother and Child (1938) was influenced by Flaherty's Inuit portraits. ${ }^{54}$ Lastly, in Christopher's biography on Flaherty, a diary entry in 1915 written by Frances Flaherty indicates that a photograph was taken of Loring and Wyle. ${ }^{55}$

There are an enormous number of archival and published sources on Flaherty that focus primarily on his career as a filmmaker. This survey shows that there has been some discussion of Flaherty as a photographer in Birnie Danzker's and Christopher's publications respectively, but that none of the sources provide an analysis of his photographs and photogravures in the context of his photographing activities.

\footnotetext{
51 Ibid, 215.

${ }^{52}$ Elspeth Cameron, And Beauty Answers: The Life of Frances Loring and Florence Wyle (Toronto: Cormorant Books, 2007), 97-98

53 Rebecca Sisler, The Girls: A Biography of Frances Loring and Florence Wyle

(Toronto: Clark, Irwin \& Company, 1974); Cameron, And Beauty Answers: The Life of Frances

Loring and Florence Wyle.

54 Elspeth Cameron, And Beauty Answers: The Life of Frances Loring and Florence Wyle,188.

${ }^{55}$ Robert Christopher, Robert and Frances Flaherty, 256.
} 


\section{Holdings of Flaherty's Photographs in Public Institutions}

Photographs taken by Flaherty are found in a number of public institutions. The Library \& Archives of Canada (LAC), has the most extensive collection of Flaherty's photographic objects in Canada, approximately fifteen hundred glass plate negatives and related prints. ${ }^{56}$ While the majority of these materials have been on loan from the Robert and Frances Flaherty Study Center, School of Theology, Claremont University in Claremont California to LAC since 1979 and 1985, LAC also has two sets of Camera Studies of the Far North portfolio in its own collections. The materials on loan to LAC from Claremont were originally donated to the Study Center by Frances Flaherty, Flaherty's widow, in 1972.

In addition to $\mathrm{AGO}$ and $\mathrm{LAC}$, other Canadian institutions with a significant collection of Flaherty's photographs and photogravures include the Notman Photographic Archives, McCord Museum, McGill University, Montreal, Quebec; Thunder Bay Historical Museum, Thunder Bay, Ontario, and The Royal Ontario Museum, Toronto, Ontario. $^{57}$

Internationally, The British Museum in London, England has an album of a hundred and two photographs taken by Flaherty in Great Whale River in 1910-1911. Flaherty deposited the album in the Museum in May $1911 .{ }^{58}$ In addition, the Revillon Frères Archives, Paris, France has thirty albums of 2,592 photographs taken during

\footnotetext{
56 Jo-Anne Birnie Danzker, Robert Flaherty, Photographer / Filmmaker: The Inuit 1910-1922. (Vancouver, British Columbia: Vancouver Art Gallery, 1979), 3.

57 Ibid, 3. These collections were not consulted due to the time and scope of this thesis.

58 This is also discussed on page 13.
} 
Flaherty's four expeditions in northern Quebec. ${ }^{59}$ According to the contract between Revillon Frères and Flaherty for the fourth expedition (1920-1921), Revillon Frères owned the copyright to all of Flaherty's images, including the ones he had taken in his first three expeditions $(1910-1916) .^{60}$

The identification of further institutions holding Flaherty's photographic works lies beyond the scope of this thesis. ${ }^{61}$

${ }^{59}$ An inventory of all the Flaherty albums has been created in a document by Michèle Therrien "Archives Revillon Photos, Inventaire Analytique" (Photocopy, Archives Publiques du Canada, Paris, February 1984).

${ }^{60}$ Robert Christopher, Robert and Frances Flaherty, 326. In the articles and essays about the north by Flaherty written after 1920, the images are copyrighted by Revillon Frères (see page 11, footnote 30). The photogravures are also imprinted with Revillon Frères " name and the copyright symbol at the bottom of each image.

61 Ten U.S. institutions that have Flaherty photographs are listed in Andrew H. Eskind's International Photography: George Eastman House Index to Photographers, Collections, and Exhibitions, vol. 2 (New York: G.K. Hall; London: Prentice Hall International, 1998). However, the institutions listed may not be the most current as this is the latest index published. In alphabetical order by State, Center for Creative Photography, The University of Arizona, Tucson, Arizona; Library of Congress, Prints \& Photographs Division, Washington, District of Columbia; National Museum of American History, Division of Photographic History, MRC 635 Smithsonian Institution, Washington, D.C.; Ball State University Art Gallery, College of Fine Arts, Ball State University, Muncie, Indiana; Albin O. Kuhn Library \& Gallery, Photography Collections, University of Maryland Baltimore County, Baltimore, Maryland; Ackland Art Museum, University of North Carolina at Chapel Hill, Chapel Hill, North Carolina; Metropolitan Museum of Art, Department of Photographs, New York, New York; George Eastman House, Rochester, New York; University of Pennsylvania Museum of Archeology and Anthropology, Philadelphia, Pennsylvania; Harry Ransom Humanities Research Center, Photography Collection, University of Austin Texas at Austin, Austin, Texas. 


\section{Introduction to the Catalogue of the Robert Flaherty Collection}

This is the full catalogue for all of the photographs and photogravures by Robert J.

Flaherty in the AGO collection. This comprises fourteen fields for the photographs and sixteen fields (the same fourteen, plus two further ones) for the photogravures. The fields are defined here in the order in which they appear in the following catalogue.

\section{AGO Accession Number}

This field records the unique item number that is assigned to every object in AGO's permanent collection. The first two digits indicate the accession year, separated by a slash and consecutive numbers of works that were accessioned that year.

For example, $87 / 323$, means that the work was acquired in 1987, and was the 323 work accessioned that year.

\section{Photographer}

This field records the name of the creator of the object, Robert J. Flaherty, followed by his dates of birth and death in brackets.

\section{Title Name(s)}

This field records the title of the photograph or photogravure, followed by its title type(s), as defined below, in brackets. In many cases, the object has more than one title.

\section{3a. Title types}

\section{a. Photographer's}

Title created by the photographer.

\section{b. Descriptive}


Title created by a cataloguer when no title is found. Many of the Flaherty materials at LAC, including that on loan from the Robert and Frances Flaherty Study Center, Claremont, California is designated as 'no title data captured' in the institutional records. I have provided descriptive titles for these within square brackets. Any titles in roman are descriptive titles given by their respective institutions.

\section{c. Imprinted}

Title is machine (letterpress) printed on the photograph or photogravure.

\section{d. Inscribed}

Title is hand-written or typed on the recto or verso of photograph, photogravure, or on the matt.

\section{e. Published}

Title as it has been published in secondary literature. These titles are italicized.

\section{f. Portfolio}

Title as it has been published for Camera Studies of the Far North.

\section{g. AGO Primary Title}

Title used for AGO exhibition labels and in AGO publications; however this title type will be phased out by AGO.

\section{h. AGO Assigned Title}

Title that is an alternative to the AGO Primary title however this title type will be phased out by AGO. 


\section{3b. Title Note}

Records that have title changes are followed by Title Note to indicate the previous title and the source of the new title.

\section{Date(s) of Object}

This field provides the date of when the object was created, followed by the date type(s), as defined below, in brackets.

None of the photographs have a print date, because determining this required more research than the scope of this project allowed. The "c." in front of the date stands for circa and indicates a date range of five years on either side of the date provided.

\section{4a. Date Types}

\section{a. Negative date}

When the negative was taken.

\section{b. Printed date}

When the photograph was printed from the negative or when the photogravure was printed.

\section{c. Published date}

When the photograph was published in primary literature or when the photogravure was published for sale.

\section{4b. Date Notes}

Records that have date changes are followed by Date Note to indicate what was previously recorded as the date and the source for the new date.

\section{Medium}

This field provides the name of the photographic or photomechanical process of the print. 


\section{Dimensions}

This field provides information about the physical dimensions of the object, with the height proceeding the width of the object in centimetres, followed by inches . This is followed by the dimension type(s), as defined below, in brackets.

\section{6a. Dimension types}

\section{a. Image}

Dimensions of only the photographic image (without borders).

b. Sheet

Dimensions of the entire support on which photographic image is printed.

\section{c. Mount}

Dimensions of the support(s) in which the photograph or photogravure has been adhered to.

\section{6b. Dimension notes}

This field elucidates information of the field above, if necessary.

\section{Inscription}

This field records all words or numbers written, typed or imprinted on the recto and verso of the print.

\section{7a. Inscription Types}
a. Imprinted
b. Inscribed
c. Numbered

\section{(Location of inscription key)}




$$
\begin{aligned}
& \text { u.l. }=\text { upper left } \\
& \text { u.c. }=\text { upper centre } \\
& \text { u.r. }=\text { upper right } \\
& \text { c.l. = centre left } \\
& \text { c }=\text { centre } \\
& \text { c.r. = centre right } \\
& \text { 1.1. = lower left } \\
& \text { l.c. = lower centre } \\
& \text { 1.r. = lower right }
\end{aligned}
$$

\section{7b. Inscription notes}

This field elucidates information of the field, if necessary.

\section{Notes}

This is a free text field that provides information on the object that cannot be stated in any other field.

\section{Alternate numbers}

This field records any additional numbers that have been assigned or associated with the object.

All of the records have an AGO ID number that was assigned when the object first entered the institution, regardless if it was accessioned or not. It was a way of tracking the object before it is legally accessioned. Some records have an alternate number for a copy negative, although it is unclear when the number was assigned and to what it refers. The negative numbers do not match the numbers in the Visual Indexes supplied by the Robert and Frances Flaherty Study Center. 


\section{Provenance}

This field provides the history of ownership of the photograph or photogravure before it entered the AGO collection.

Little is known about the provenance of the works. The donors are the estates of Frances Loring and Florence Wyle (1983); Sandra Ball and Marcia Reid (1987); Susan Osborn (1992); Gordon M. Robb (1993) and an anonymous donor (2007). None of the donors were allowed to be contacted. The only piece of relevant information discovered was that Robb's collection of photographs by Flaherty (including the unattributed ones) were inherited from his Grandmother to whom Flaherty had given the photographs, perhaps in lieu of payment for room and board. ${ }^{62}$

\section{Exhibition History}

This field provides information on the photograph or photogravure's exhibition history at the AGO and as loans to other institutions (if applicable) after it entered the AGO's collection.

\section{References}

This field provides bibliographic information in secondary literature, where the object has been written about and/or reproduced.

\section{2a. Reference types}

\section{a. Published references}

${ }^{62}$ Maia-Mari Sutnik, e-mail message to author, June 2, 2010. 
The publications are abbreviated. Please see bibliography for full bibliographic entries.

\section{b. Unpublished references}

The Visual Indexes provided by the Robert and Frances Flaherty Study Center, School of Theology, Claremont University in Claremont, California, comprise three separate PDF documents accessed via the Internet. These contain images of Flaherty's negatives, photographs and photogravures. There are thirty-five images per page and each image has an item number that starts with "N". These images and item numbers correspond to the actual objects on loan from the Study Center to LAC.

\section{Related object(s) at AGO}

This field provides information on related object(s) in the AGO that were printed from the same negative or gravure plate.

The related object's AGO accession number is provided. In the case where there is no accession number, a description of where the related object can be found is noted.

\section{Related object(s) at Library and Archives of Canada (LAC)}

This field provides information on related object(s) examined at the Preservation Centre (Archives) in Gatineau, Quebec, Library \& Archives of Canada.

This field includes the title, item number, other accession number and copy negative number of the relevant object(s) ${ }^{63}$ The object(s) at LAC are on different types of support including positive transparencies, negatives, and photographs. Most of the objects that were printed from the same negative have the same item level number, while some related objects have different item level numbers. Although only selected images of

\footnotetext{
${ }^{63}$ Item numbers were found using the number that matched the image in the Visual Index. For example, "N304" would be entered as "0304" on the LAC website. Records of objects are searchable at http://www.collectionscanada.gc.ca/ (Archives Search page).
} 
related objects are illustrated in this catalogue, all are listed and described. Please also note that the copy negatives are not described in this field, but only their number appear for reference purposes.

Other Canadian and international institutions, include the Royal Ontario Museum and Thunder Bay Historical Museum have substantial Flaherty material, and may have related objects to those in the AGO. These are noted in the record if the information was available.

The PORTFOLIO records have the fourteen fields as described above; in addition, they have two further fields.

\section{Portfolio}

This field provides the name of the portfolio in which the photogravure appeared.

All of the photogravures in the AGO collection belong to Camera Studies of the Far North.

\section{Constituents (object related)}

This field records person(s) or organization, beyond that of the photographer, affiliated with the creation and publication of the object.

\section{6a. Types of Constituents}
a. Publisher
b. Image copyright holder
c. Photogravure printer

\section{6b. Constituent notes}

This field elucidates information of the field above, if necessary. 


\section{Index Catalogue}

The catalogue has been organized into four sections: 1) twenty-three photographs of northern Arctic scenes and portraits; 2) nineteen photogravures of northern Arctic scenes and portraits; 3) two presently unattributed photographs of northern scenes that are associated with Flaherty's work of the north; and 4) seven portraits of Loring and Wyle taken in Toronto, Ontario. Within each group, the records are organized by their accession number from the earliest to the latest accession (indicated by the first two or four digits), except for duplicate copies of the same photogravure or related works in the Loring and Wyle section. These are grouped together in their respective sections for ease of comparison.

\section{Photographs of the North (1910-1921)}

1. Unidentified (Young Woman), Baffin Island, AGO 93/977

2. Two Women Carrying Wood, James Bay?, AGO 93/278

3. Unidentified Portrait of Inuit Child, AGO 93/279

4. Unidentified (Man), Baffin Island, AGO 93/280.1

5. Enutsiak (Innutsiak), Baffin Island, AGO 93/280.2

6. Man (possibly Ezechiak), Baffin Island, AGO 93/280.3

7. Nascaupie Indian Chief, Northern Labrador, AGO 93/280.4

8. Tooktoo (The Deer), Chief of Sikoslingmuit Eskimos [identified as Anumniuq], Southern Baffin Island, AGO 93/280.5

9. Sada, Sikoslingmuit Eskimo of Southern Baffin Island, AGO 93/280.6

10. (Mother and Two Children), Ungava Peninsula?, AGO 93/280.7

11. Unidentified Inuit Child (Ungava Peninsula, Quebec), AGO 93/280.8 
12. Seated Eskimo over Seal Breathing Hole - with Harpoon, AGO 93/280.9

13. Unidentified Inuit Child (Ungava Peninsula, Quebec), AGO 93/280.10

14. Unidentified (Young Girl with Plaid Shawl) Ungava Peninsula, AGO 93/280.11

15. Unidentified (Man in Profile), Fort Chimo?, AGO 93/280.12

16. Unidentified Naskapi or Montagnais Indian with Snowshoes on his back, Fort Chimo, AGO 93/280.13

17. Unidentified (Child), Baffin Island, AGO 93/280.14

18. Unidentified (Woman), Chesterfield Inlet, AGO 93/280.15

19. Unidentified (Ezechiak),Baffin Island, AGO 93/280.16

20. Unidentified (Woman in Hood), Baffin Island, AGO 93/280.17

21. Sapa? (In Fur Hood), Baffin Island, AGO 93/280.18

22. Tooktoo (The Deer), Southern Baffin Island, AGO 93/280.19

23. Unidentified (Old Man), Baffin Island, AGO 93/280.20

\section{Photogravures of the North (1921-1922)}

24. Eskimo Omiak in the Spring, AGO 92/89.1

25. The Walrus Hunter, AGO $92 / 89.2$

26. The Barren Lands, Northern Ungava, AGO 92/89.3

27. Youthful Hunter, AGO 92/89.4

28. Abandoned Eskimo Village, AGO 92/89.5

29. A Labrador Cree (Indian), Northern Labrador, AGO 92/89.7

30. Sapa, Sikoslingmuit Eskimo of Southern Baffin Land, AGO 92/89.9

31. Nascaupie, Indian Chief, Northern Labrador, AGO 92/89.10

32. Canayou (The Sculpin), Sikoslingmuit Eskimo Girl, Southern Baffin Land, AGO 92/89.11 
33. Nyla and Child, Eteeveemuit Eskimo of Cape Dufferin, Northwestern Ungava, AGO 2007/159.4

34. Allegoo (Shining Water), Sikoslingmuit Eskimo Woman, Southern Baffin Land, AGO 2007/159.5

35. Summer (August), Eskimo Kayak in Northeastern Hudson Bay, AGO 87/322

36. Summer (August), Eskimo Kayak in Northeastern Hudson Bay, AGO 92/89.6

37. The Hunter, Eskimo in the Rough Ice Fields at Sea, AGO 87/323

38. The Hunter, Eskimo in the Rough Ice Fields at Sea, AGO 2007/159.3

39. The Huskie (The Wolf Dog of the Eskimos), AGO $87 / 324$

40. The Huskie (The Wolf Dog of the Eskimos), AGO 2007/159.2

41. Tooktoo (The Deer), Chief of Sikoslingmuit Eskimos, Southern Baffin Land, AGO 92/89.8

42. Tooktoo (The Deer), Chief of Sikoslingmuit Eskimos, Southern Baffin Land, AGO 2007/159.1

\section{Unattributed Photographs of the North}

43. Moose Factory, AGO 93/280.21

44. Huskies on Ice, Hudson's Bay Area, AGO 93/280.22

\section{Portraits of Frances Loring and Florence Wyle}

45. Frances Loring, AGO 86/112

46. Profile of Frances Loring, AGO 86/113

47. Frances Loring with Shawl, AGO 86/111

48. Portrait - Frances Loring, AGO 86/115

49. Portrait of Frances Loring and Florence Wyle (Church Street, Toronto), AGO 86/116

50. Portrait of Frances Loring and Florence Wyle (Church Street, Toronto), AGO 86/117

51. Portrait of Florence Wyle (Church Street, Toronto), AGO 86/114 


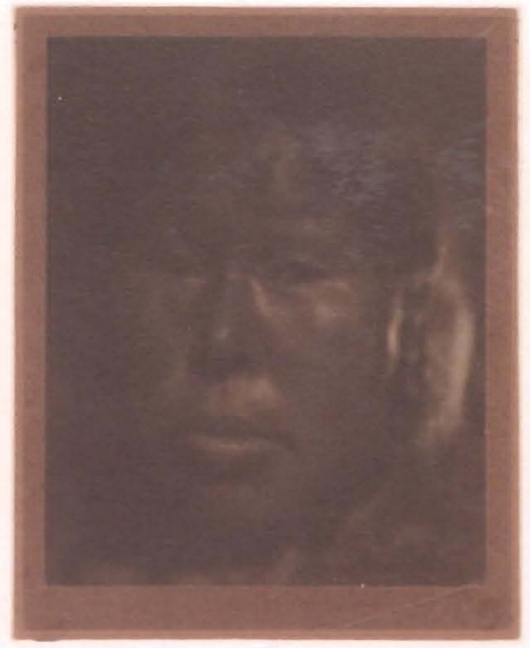

\section{CATALOGUE I}

AGO accession number: 93/277

Photographer: Robert J. Flaherty (|884-1951)

Title name: Unidentified (Young Woman), Baffin Island (Descriptive, AGO Primary title)

Date of object: 1913-1914 (Negative date)

Date note: Date previously part of title. Date derives from Independent researcher, Janet Dewan's research of the Flaherty collection at AGO in 1994.

Medium: Gelatin silver bromide print

Dimensions: Image: $20.8 \times 16.6 \mathrm{~cm}(8$ 3/16 ×69/16 in.); Sheet: $20.81 \times 6.6 \times \mathrm{cm}(83 / 16 \times 69 / 16$ in.); Ist Mount: $23.2 \times 18.4 \mathrm{~cm}(91 / 8 \times 7$ l/4 in.); 2nd Mount: $23.8 \times 19 \mathrm{~cm}(93 / 8 \times 7 / / 2 \mathrm{in}$.)

\section{Inscription: None}

\section{Alternate number: AGO ID\# 21777}

Notes: (Verso on 2nd mount:) u.r., u.l., I.r., I.I. have residual black paper adhere to card stock mount.

Related object at AGO: None

Provenance: Gift of Gordon M. Robb, 1993

Exhibition history: "Robert Flaherty: Camera Studies", AGO, 15 June - 18 September 1994

References (unpublished): The Robert and Frances Study Center, School of Theology. "A Visual Index to the Flaherty Still Photographs: Nanook 2001-24I6." Claremont University http://www.cst.edu/flaherty/VIS INDEX_NANOOK_2001.pdf, page 5, frame N2106.
LAC reference numbers: Item number 2106; Other accession number 1985-105 NPC; Copy negative PA-500796.

On loan from The Robert and Frances Flaherty Study Center, School of Theology, Claremont University, Claremont, California.

Related object at LAC: [Unidentified woman] (Figure I and 2) Gelatin glass plate negative. Image: $17.5 \times 12.1 \mathrm{~cm}$; Sheet (glass): $17.7 \times 12.6 \times \mathrm{cm}$. Inscriptions: (verso) u.l.." 396 " inscribed in ink on white paper adhered to glass; I.r.c.:" "FN294F" inscribed in black ink.

(Fig. I) Recto

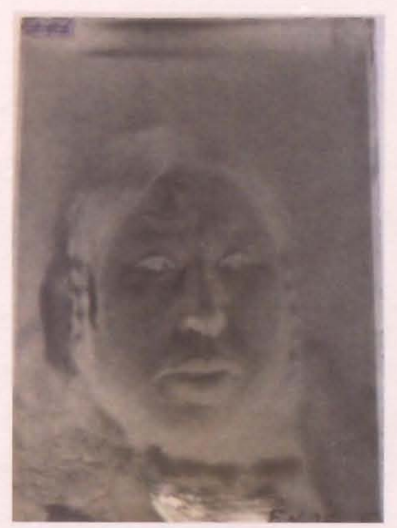

(Fig. 2) Verso

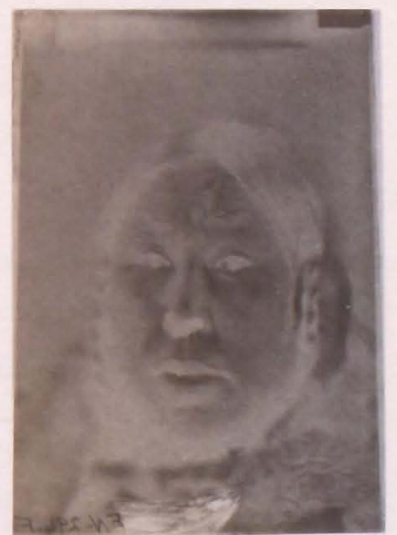

Unidentified Woman

Gelatin glass plate negative

LAC on loan from The Robert and Frances Flaherty Study Center, School of Theology, Claremont University, Claremont, California

(Credit: Robert J. Flaherty / Library and Archives of Canada / PA-500796) 


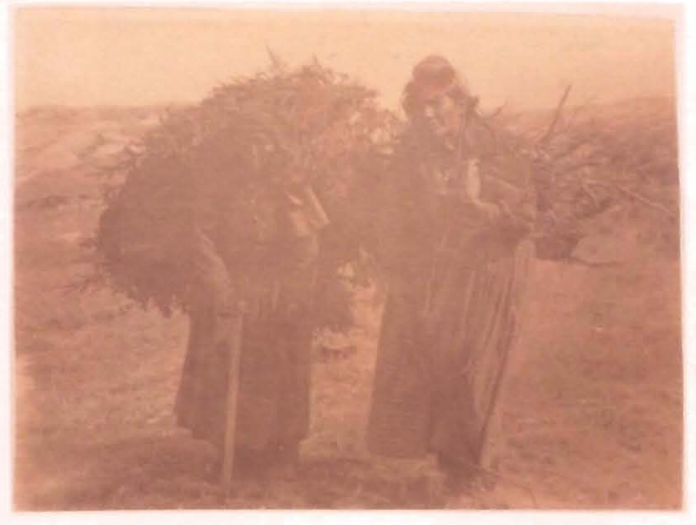

CATALOGUE 2

AGO accession number: 93/278

Photographer: Robert J. Flaherty (1884-1951)

Title name: Two Women Carrying Wood, James Bay? (Descriptive, AGO Primary Title, Inscribed on matte)

Date of object: 1910-1912 (Negative date)

Date note: Date previously part of title. Date derives from independent researcher, Janet Dewan's research of the Flaherty collection at AGO in 1994.

Medium: Gelatin silver bromide print

Dimensions: Image: $15.3 \times 20 \mathrm{~cm}(6 \times 77 / 8 \mathrm{in}$. $)$

Sheet: $15.3 \times 20 \mathrm{~cm}(6 \times 77 / 8 \mathrm{in}$. $)$

Inscription: (Verso) u.r:."\#2".

Type of inscription: Numbered (in graphite)

Alternate number: AGO ID\#21778

Related object at AGO: None

Provenance: Gift of Gordon M. Robb, 1993

Exhibition history: None

References: None

Related object at LAC: None

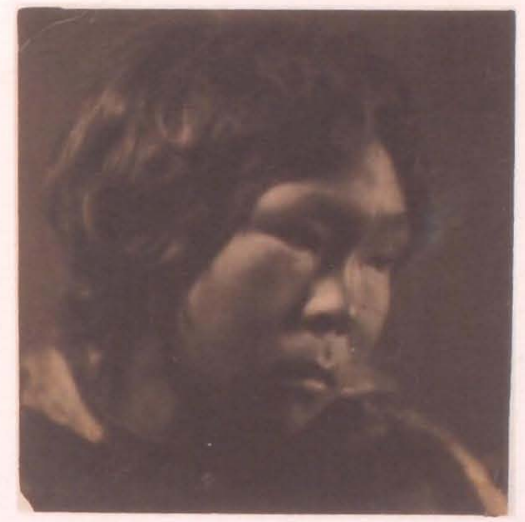

\section{CATALOGUE 3}

AGO accession number: 93/279

Photographer: Robert J. Flaherty (1884-1951)

Title names: Unidentified Portrait of Inuit Child (Descriptive); Unidentified (Young Woman) (Descriptive, AGO Primary Title, Inscribed on matte)

Date of object: $1913-1914$ (Negative date)

Date note: Date previously part of title. Date derives from Independent researcher, Janet Dewan's research of the Flaherty collection at AGO in 1994.

Medium: Gelatin silver bromide print

Dimensions: Image: $20 \times 20 \mathrm{~cm}(77 / 8 \times 77 / 8$ in. $)$

Sheet: $20 \times 20 \mathrm{~cm}(77 / 8 \times 77 / 8 \mathrm{in}$.)

Inscription: None

Alternate number: AGO ID\# 21779

Related object at AGO: None

Provenance: Gift of Gordon M. Robb, 1993

Exhibition history: "Robert Flaherty: Camera Studies", AGO, 15 June 1994 - 18 September 1994

References (unpublished): The Robert and Frances Study Center, School of Theology. "A Visual Index to the Flaherty Still Photographs: Nanook 24I7-end." Claremont University http://wmw.cst.edu/flaherty/VIS_INDEX_NANOOK_2417.pdf, page 3, frame N2478.

Related object at LAC: [Unidentified Portrait of Inuit Child]. Gelatin silver print (on matte paper). Image: $13.7 \times 14.9 \mathrm{~cm}$; Sheet: $13.7 \times 14.9 \mathrm{~cm}$. Inscriptions: (Verso) u.r.: "N2478"; I.r.:" 1985-105"; I.c.: "PA-143729" all inscribed with graphite.LAC reference numbers: Item number 2478; Other accession number 1985-105 NPC; copy negative PA-143729. On loan from The Robert and Frances Flaherty Study Center, School of Theology, Claremont University, Claremont, California. 


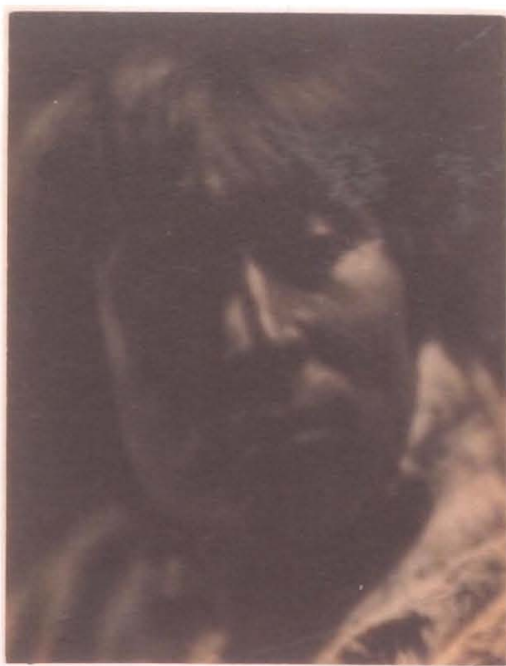

\section{CATALOGUE 4}

AGO accession number: 93/280.1

Photographer: Robert J. Flaherty (|884-195|)

Title names: Unidentified, (Man), Baffin Island

(Descriptive, AGO Primary Title, Inscribed on matte)

Date of object: 1913 - 1914 (Negative date)

Date note: Date previously part of title. Date derives from Independent researcher, Janet Dewan's research of the Flaherty collection at AGO in 1994.

Medium: Gelatin silver bromide print

Dimensions: Image: $25.3 \times 19.5 \mathrm{~cm}(915 / 16 \times 711 / 16$ in.); Sheet: $25.3 \times 19.5 \mathrm{~cm}(9 / 5 / 16 \times 711 / 16 \mathrm{in}$.

Inscription: None

Alternate number: AGO ID\# 21792; Photo Negative Number N-9507

Related object at AGO: None

Provenance: Gift of Gordon M. Robb, 1993

Exhibition history: None

References: None

Related object at LAC: None

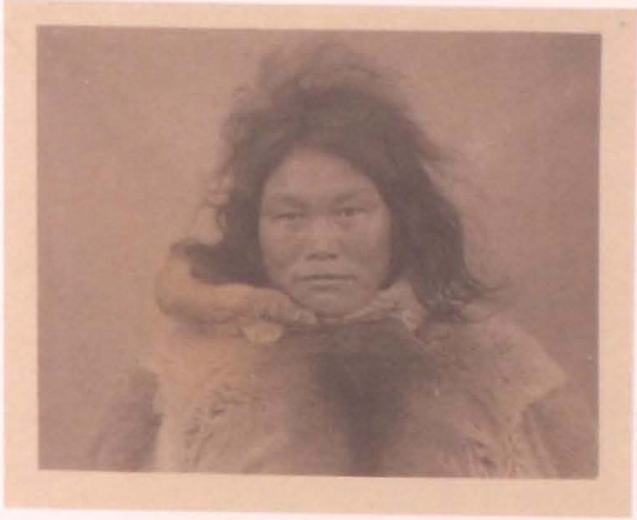

\section{CATALOGUE 5}

AGO accession number: 93/280.2

Photographer: Robert J. Flaherty (|884-195|)

Title names: Enutsiak (Innutsiak), Baffin Island (Descriptive, AGO Primary Title, Inscribed on matte)

Date of object: 1913 - 1914 (Negative date)

Date note: Date previously part of title. Date derives from Independent researcher, Janet Dewan's research of the Flaherty collection at AGO in 1994.

Medium: Gelatin silver print

Dimensions: Image: $8.8 \times 11.3 \mathrm{~cm}(37 / 16 \times 47 / 16 \mathrm{in}$.); Sheet: $19 \times 22.9 \mathrm{~cm}(71 / 2 \times 9$ in. $)$

Inscription: None

Alternate number: AGO ID\# 22132

Notes: Originally in album that contained 20 photographs; album pages were originally numbered in graphite (as noted by AGO conservator); there is residual black paper adhered to the verso of the sheet ( u.r., u.l., I.r., I.I.). The album was the donor's possession and was discarded by the AGO; see appendix B.

Related object at AGO: None

Provenance: Gift of Gordon M. Robb, 1993

Exhibition history: "Robert Flaherty: Camera Studies", AGO, 15 June 1994 - 18 September 1994

References (published): Birnie Danzker, Jo-Anne. Robert Flaherty, Photographer / Filmmaker:The Inuit I I0-1922. Vancouver, British Columbia:Vancouver Art Gallery, 1979. pages 35, 85 (cat. 21); Birnie Danzker, Jo-Anne, "Robert Flaherty/ Photographer", Studies in Visual Communication, 6, No.2, Summer 1980, 19 (illustration and catalogue 21). 
References (unpublished): The Robert and Frances Study Center, School of Theology. "A Visual Index to the Flaherty Still Photographs: Nanook 200 I-24I6 and 2417-end." Claremont University http://wnw.cst.edu/ flaherty/VIS_INDEX_NANOOK_200I.pdf, page 4, frame N2096; http://umw.cst.edu/flaherty/VIS_INDEX_NANOOK_2417.pdf, page 2, frame N2433.

Related objects at LAC: There are two related objects on loan from The Robert and Frances Flaherty Study Center, School of Theology, Claremont University, Claremont, California to LAC. These objects have different titles and $L A C$ reference numbers.

\section{1. [Unidentified man] (Figure 3)}

Gelatin silver glass plate negative Image: $9.5 \mathrm{~cm} \times 12 \mathrm{~cm}$; Sheet (glass): $10.2 \times 12.6$. Inscriptions: (Verso) u.r:: "FN-293F"; I.r.: "FN-293F" both inscribed in black ink. LAC reference numbers: Item number 2096; Other accession Number 1985-105 NPC; Copy negative PA- I 1408.

\section{Portrait of Enutsiak (Innutsiak) (Figure 4)}

Gelatin silver glass lantern slide

Sheet (glass): $8.3 \times 10.1 \mathrm{~cm}$

LAC reference numbers: Item number 2433; Other accession number 1979-242 NPC; Copy negative PA$1 / 4220$.

There is also prints in the collection of Thunder Bay Historical Museum and the Royal Ontario Museum, as described and illustrated in the catalogue by Bimie Danzker, page 85 , catalogue 21 , cited in References (published).

\section{(Fig. 3) Verso}

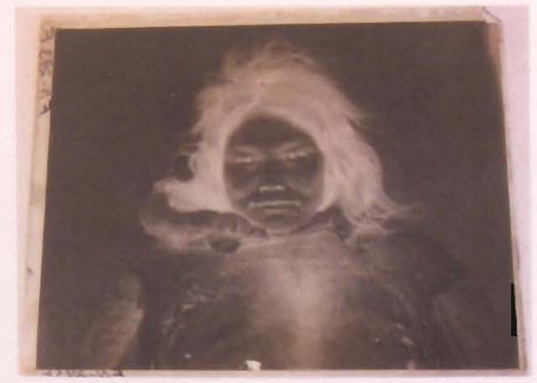

\section{Unidentified Man}

Gelatin silver glass plate negative

On loan from The Robert and Frances Flaherty Study

Center,

School of Theology, Claremont University, Claremont, California
(Credit: Robert ). Flaherty / Library and Archives of Canada / PA- I 14089)

(Fig. 4)

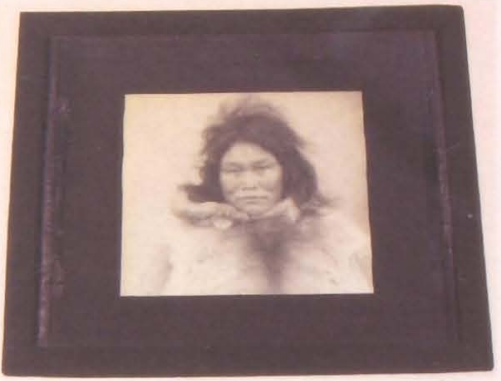

Portrait of Enutsiak (Innutsiak)

Gelatin silver glass lantern slide

On loan from The Robert and Frances Flaherty Study

Center,

School of Theology, Claremont University, Claremont, California

(Credit: Robert J. Flaherty / Library and Archives of Canada / PA-I | 4220) 


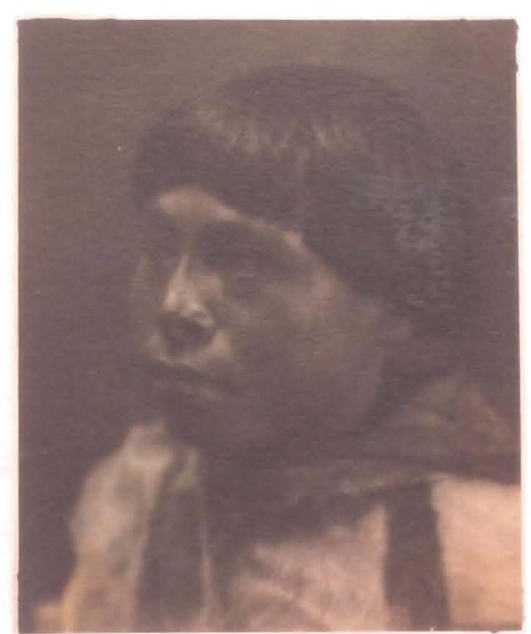

\section{CATALOGUE 6}

AGO accession number: $93 / 280.3$

Photographer: Robert J. Flaherty (|884-1951)

Title names: Man (possibly Ezechiak), Baffin Island (Descriptive); Unidentified (Child), Baffin Islands, 19131914 (Descriptive, AGO Primary Title, Inscribed on matte)

Title note: Previous title: [Unidentified (Child), Baffin Islands, 1913-1914]. New title adapted from catalogue by Birnie Danzker, page 86 (Catalogue 44). Catalogue has a different photograph but the pose is similar and the same man appears in it.

Date of object: 1913 - 1914 (Negative date)

Date note: Date previously part of title. Date derives from Independent researcher, Janet Dewan's research of the Flaherty collection at AGO in 1994.

Medium: Gelatin silver bromide print

Dimensions: Image: $23 \times 18.6 \mathrm{~cm}(9 \mathrm{l} / 16 \times 75 / 16 \mathrm{in}$ ); Sheet: $23 \times 18.6 \mathrm{~cm}(91 / 16 \times 75 / 16 \mathrm{in}$.)

Inscription: None

\section{Alternate number: AGOID\# 22133}

Notes: Originally in album that contained 20 photographs; Album pages were originally numbered in graphite (as noted by AGO conservator); There are residual black paper adhered to the verso of the sheet ( u.r., u.l., I.r., I.I.). The album was the donor's possession and was discarded by the AGO. see appendix B.

Related object at AGO: None

Provenance: Gift of Gordon M. Robb, 1993

Exhibition history: None

References: None

Related object at LAC: None

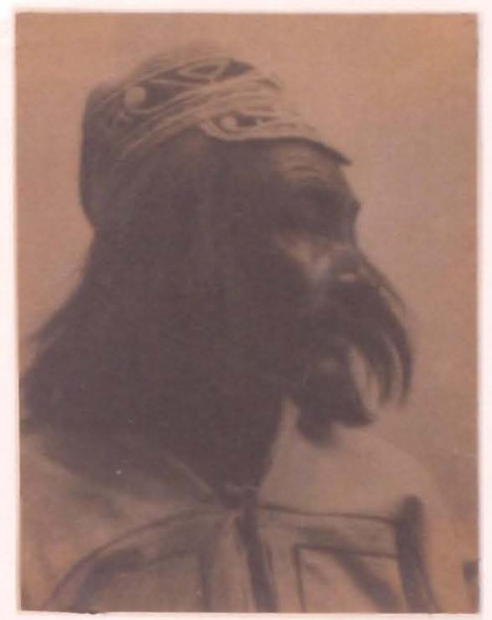

\section{CATALOGUE 7}

AGO accession number: 93/280.4

Photographer: Robert J. Flaherty (|884- |95|)

Title names: Nascaupie Indian Chief, Northern Labrador (Descriptive, AGO Primary Title, Inscribed on matte)

Date of object: 1910-1916 (Negative date)

Date note: "c. 1912" Date previously part of title

Medium: Gelatin silver bromide print

Dimensions: Image: $24.5 \times 18.9 \mathrm{~cm}(95 / 8 \times 77 / 16$ in.); Sheet: $24.5 \times 18.9 \mathrm{~cm}(95 / 8 \times 77 / 16 \mathrm{in}$.)

Inscription: None

Alternate number: AGOID\# 22134; Photo Negative Number $\mathrm{N}-9512$

Notes: Originally in album that contained 20 photographs; album pages were originally numbered in graphite (as noted by AGO conservator); there is residual black paper adhered to the verso of the sheet ( u.r., u.l., I.r., I.I.). The album was the donor's possession and was discarded by the AGO; see appendix B.

Related object at AGO: Catalogue 31 (AGO Acc. No. $92 / 89.10$ ) is the photogravure from the same negative

Provenance: Gift of Gordon M. Robb, 1993

Exhibition history: "Robert Flaherty: Camera Studies", AGO, 15 June 1994 - 18 September 1994

References (unpublished): The Robert and Frances Study Center, School of Theology. "A Visual Index to the Flaherty Still Photographs: Nanook 000 I-0383." Claremont University http://mmw.cst.edu/flahertyNIS_INDEX_NANOOK_000I.pdf, page 6, frame NI52. 
Related object at LAC: According to LAC records, there is a related object of this photograph, however the object (described below) was not found in April 2010.

I. Indian Chief Nascaupie, Northern Labrador

Gelatin silver cellulose nitrate negative

LAC reference numbers: Item number O 152; Other accession number 1979-242 NPC; Copy negative PA121983. On loan from The Robert and Frances Flaherty Study Center, School of Theology, Claremont University, Claremont, California.

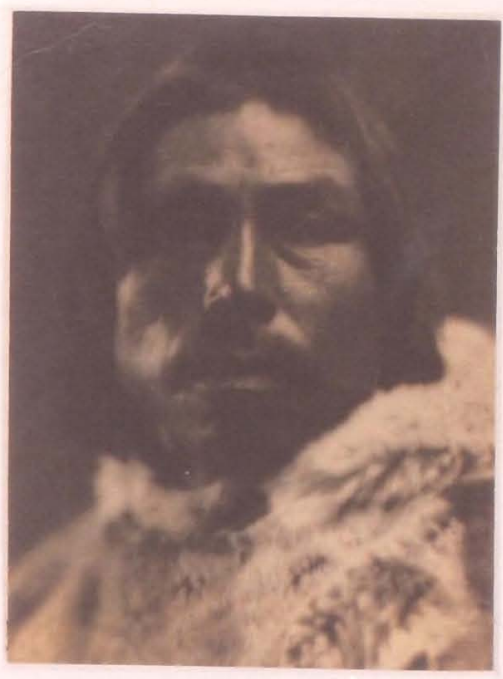

\section{CATALOGUE 8}

AGO accession number: 93/280.5

Photographer: Robert J. Flaherty (|884-195|)

Title names: Tookoo (The Deer), Chief of Sikoslingmuit Eskimos [identified as Anumniuq], Southern Baffin Island (Descriptive); Tookoo (The Deer), Chief of Sikoslingmint Eskimos, Southern Baffin Island, 1913-1914 (Descriptive, AGO Primary Title, Inscribed on matte)

Date of object: 1913-1914 (Negative date)

Date note: Date previously part of title

Medium: Gelatin silver bromide print

Dimensions: Image: $21.4 \times 16.5 \mathrm{~cm}$; Sheet: $49 \times 33 \mathrm{~cm}$

Inscription: (Verso) u.c.." "39|" (Inscribed in graphite)

Alternate number: AGOID \# 22135; Photo Negative Number $\mathrm{N}-951$ ।

Notes: Originally in album that contained 20 photographs; album pages were originally numbered in graphite (as noted by AGO conservator); there is residual black paper adhered to the verso of the sheet ( u.r., u.I., I.r., I.I.). The album was the donor's possession and was discarded by the AGO; see appendix B.

Related object at AGO: Catalogue 4I (AGO Acc. No. 92/89.8) and catalogue 42 (AGO Acc. No. 2007/159.1) are copies of the photogravure printed made from the same negative. Also catalogue 22 (same man in image but in a different pose).

Provenance: Gift of Gordon M. Robb, 1993

Exhibition history: "Robert Flaherty: Camera Studies", AGO, 15 June - 18 September 1994;" Connecting with Photography", Elliott Gallery, AGO, November 14, 2008 May 24, 2010. 
References (unpublished): The Robert and Frances Study Center, School of Theology. "A Visual Index to the Flaherty Still Photographs: Nanook 000 I-0383." Claremont University http://www.cst.edu/flaherty/VIS_INDEX_NANOOK_OOOI.pdf, page 6, frame NI5I.

Related objects at LAC: There are two related objects on loan from The Robert and Frances Flaherty Study Center, School of Theology, Claremont University, Claremont, California to LAC. These object have the same $L A C$ reference numbers: Item number 0 I5 I; Other accession number 1979-242 NPC; Copy negative PA121985.

I. [Man identified as Anumniuq] (Figure 5)

Collodion printing-out paper (according to Archivist at LAC). Image: $14.6 \times 10.5 \mathrm{~cm}$; Sheet: $14.6 \times 10.5 \mathrm{~cm}$ Inscriptions: (Verso) C: "C" inscribed in blue graphite/ "NI5I" inscribed in graphite; 1.1.:" I985-105" inscribed in graphite. Note: Inscription on the verso has a different accession number from the one stated in the record.

2. [Man identified as Anumniuq] (Figure 6) Gelatin silver glass lantern slide. Sheet (glass): $10.2 \times 8.3 \mathrm{~cm}$. Inscription: (Recto) u.l.:" NI5I" inscribed in ink on sticker label.

(Fig. 5)

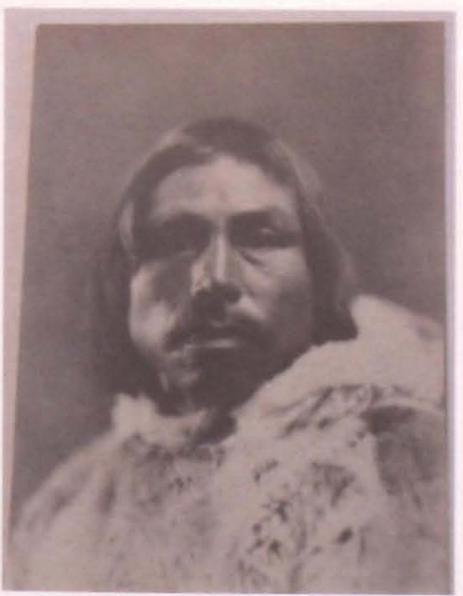

Man identified as Anumniuq

Collodion printing-out paper

On loan from The Robert and Frances Flaherty Study Center, School of Theology, Claremont University, Claremont, California

(Credit: Robert J. Flaherty / Library and Archives of Canada / PA-121985)
(Fig. 6)

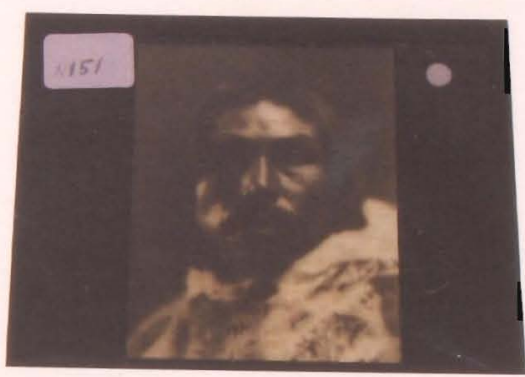

Man identified as Anumniuq

Gelatin silver glass lantern slide

On loan from The Robert and Frances Flaherty Study Center, School of Theology, Claremont University,

Claremont, California

(Credit: Robert J. Flaherty / Library and Archives of Canada / PA-121985) 


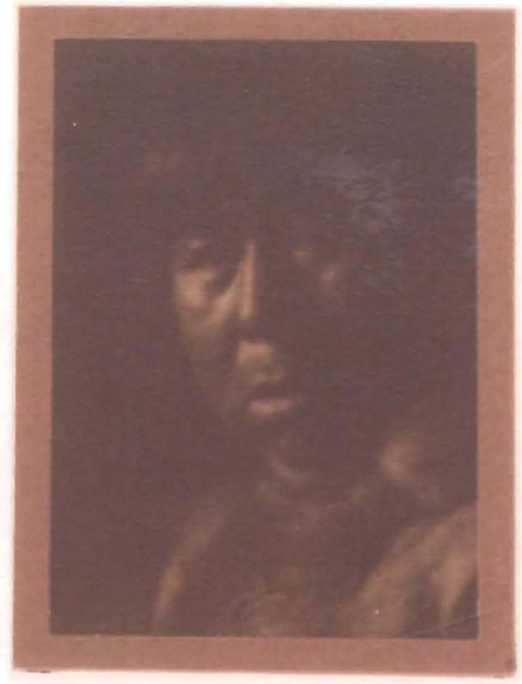

\section{CATALOGUE 9}

AGO accession number: 93/280.6

Photographer: Robert J. Flaherty (|884-|95|)

Title names: Sada, Sikoslingmuit Eskimo of Southern Baffin Island (Descriptive, AGO Primary Title, Inscribed on matte)

Title note: Previous spelling of "Sikoslingmuir" corrected

Date of object: 1913 - 1914 (Negative date)

Date note: Date previously part of title. Date derives from Independent researcher, Janet Dewan's research for the Flaherty works at AGO in 1994.

Medium: Gelatin silver bromide print

Dimensions: $21.3 \times 15.1 \mathrm{~cm}(83 / 8 \times 515 / 16$ in.); Sheet: $21.3 \times 15.1 \mathrm{~cm}(83 / 8 \times 5 / 5 / 16 \mathrm{in}$.); Mount: $23.7 \times 17.7 \mathrm{~cm}(95 / 16 \times 6 / 5 / 16 \mathrm{in}$.

Inscription: None

\section{Alternate number: AGOID \# 22136}

Notes: Originally in album that contained 20 photographs; album pages were originally numbered in graphite (as noted by AGO conservator); there is residual black paper adhered to the verso of the sheet ( u.r., u.I., I.r., I.I.). The album was the donor's possession and was discarded by the AGO; see appendix $B$.

Related object at AGO: None

Provenance: Gift of Gordon M. Robb, 1993

Exhibition history: None

Related objects at LAC: None

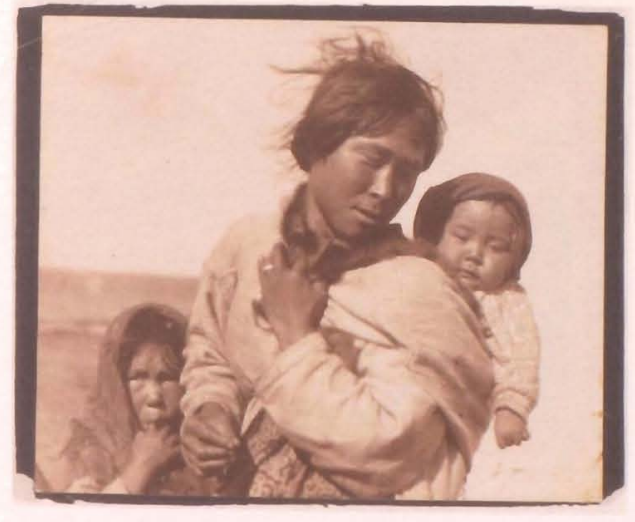

\section{CATALOGUE 10}

AGO accession number: 93/280.7

Photographer: Robert J. Flaherty (1884-|95|)

Title names: (Mother and Two Children), Ungava Peninsula? (Descriptive, AGO Primary title); (Mother and Two Children), Ungava Peninsula? c. 1912 (Inscribed on matte)

Date of object: 1910-1916 (Negative date)

Date note: "c. 1912" previously part of title

Medium: Toned gelatin silver print

Dimensions: Image: $21 \times 25.4 \mathrm{~cm}$

Sheet: $21 \times 25.4 \mathrm{~cm}$; Mount: $21 \times 27.3 \mathrm{~cm}$

Inscription: None

Alternate number: AGOID \# 22137; Photo Negative Number $\mathrm{N}-9518$

Notes: Originally in album that contained 20 photographs; album pages were originally numbered in graphite (as noted by AGO conservator); there is residual black paper adhered to the verso of the sheet ( u.r., u.l., I.r., I.I.). The album was the donor's possession and was discarded by the AGO; see appendix B.

Related object at AGO: None

Provenance: Gift of Gordon M. Robb, 1993

Exhibition history: "Robert Flaherty: Camera Studies", AGO, 15 June - 18 September 1994;" Connecting with Photography", Elliott Gallery, AGO, November 14, 2008 - May 24, 2010.

References (unpublished): The Robert and Frances Study Center, School of Theology. "A Visual Index to the Flaherty Still Photographs: Nanook 2417- end." Claremont University http://www.cst.edu/flaherty/ VIS_INDEX_NANOOK_24I7.pdf, page 2, frame N2426. 
Related objects at LAC: [Unidentified woman and two children] (Figure 7)

Gelatin silver glass lantern slide. Sheet (glass): $8.3 \times 8.3 \mathrm{~cm}$. Inscription: (Recto) I.I.:" "93" inscribed in graphite on sticker label. LAC reference numbers: Item number 2426; Other accession number 1985- 105 NPC; Copy negative PA1 1 4239. On loan from The Robert and Frances Flaherty Study Center, School of Theology, Claremont University, Claremont, California.

(Fig. 7)

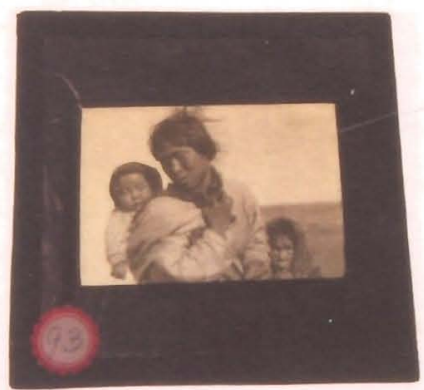

Unidentified Woman and Two Children

Gelatin silver glass lantern slide

On loan from The Robert and Frances Flaherty Study Center:

School of Theology, Claremont University, Claremont, California

(Credit: Robert J. Flaherty / Library and Archives of Canada / PA- I | 4239)

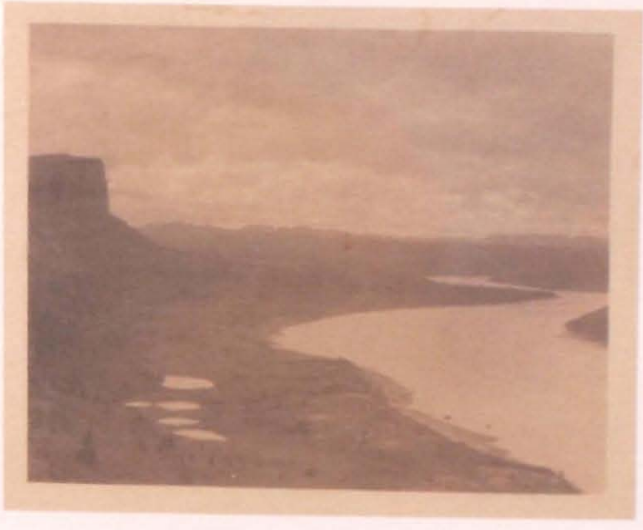

\section{CATALOGUE I I}

AGO accession number: 93/280.7

Photographer: Robert J. Flaherty (| 884-|95|)

Title names: Landscape, River (Descriptive, AGO Primary Title, Inscribed on matte)

Date of object: 1910-1916 (Negative date)

Date note: Date was previously unknown

Medium: Gelatin silver bromide print

Dimensions: Image: $8.8 \times 11.3 \mathrm{~cm}(37 / 16 \times 4$

$7 / 16$ in.)

Sheet: $19 \times 22.8 \mathrm{~cm}(7 / / 2 \times 9$ in. $)$

Inscription: None

Alternate number: AGOID\# 22138

Notes: Originally in album that contained 20 photographs; album pages were originally numbered in graphite (as noted by AGO conservator); there is residual black paper adhered to the verso of the sheet ( u.r., u.l., I.r., I.I.). The album was the donor's possession and was discarded by the AGO; see appendix B.

Related object at AGO: None

Provenance: Gift of Gordon M. Robb, 1993

\section{Exhibition history: None}

References (unpublished): The Robert and Frances Study Center, School of Theology. "A Visual Index to the Flaherty Still Photographs: Nanook 000 I-0383." Claremont University http://www.cst. edu/flaherty/VIS_INDEX_NANOOK_000 I.pdf, page 2, frame N029. 
There are two related objects on loan from The Robert and Frances Flaherty Study Center, School of Theology, Claremont University, Claremont, California to LAC. These object have the same title and $L A C$ reference numbers: Item number 029; Other accession number 1985-105 NPC; Copy negative PA-143312.

I. [View of Landscape and River] (Figure 8)

Gelatin silver glass plate negative: Image: $9.5 \times 12 \mathrm{~cm}$; Sheet (glass): $10.1 \times 12.6 \mathrm{~cm}$. Inscription: (Recto) I.I.: "408" (upside down) inscribed in ink on white label. (Verso) u.l.:" "FN-29"; u.r.: "FN-29"; I...:"F/N-29"; I.r.: "FN29" all inscribed in ink.

\section{2. [View of Landscape and River] (Figure 9)}

Gelatin silver print on glossy paper. Image: $9 \times 11.7 \mathrm{~cm}$; Sheet: $9.8 \times 11.9 \mathrm{~cm}$; Image: $11.7 \times 9 \mathrm{~cm}$. Inscription: (Recto) I.r.: "408" inscribed in ink. (Verso) u.l.:. "N29" inscribed in graphite; c: "C" [?] inscribed in blue graphite; 1.1.: "I985-105" inscribed in graphite; I.r:." 54 [?] inscribed in graphite.

Note: (Verso) u.r. and I.r has residual black paper glued to photograph.

\section{(Fig. 8) Recto}

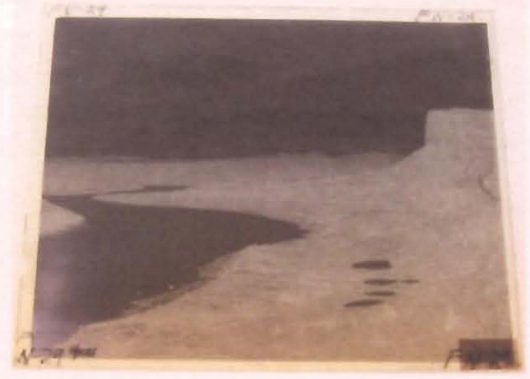

View of Landscape and River

Gelatin silver glass plate negative

On loan from The Robert and Frances Flaherty Study Center,

School of Theology, Claremont University, Claremont, California.

(Credit: Robert J. Flaherty / Library and Archives of Canada / PA- 143312)

\section{(Fig. 9)}

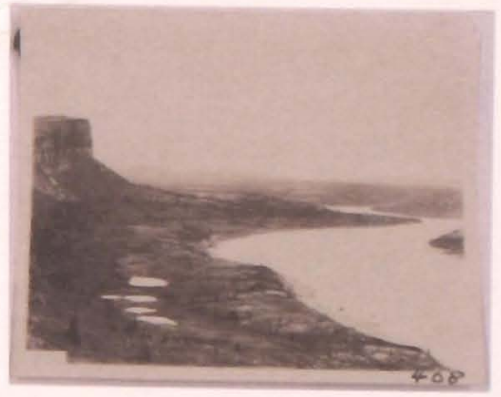

View of Landscape and River

Gelatin silver print

On loan from The Robert and Frances Flaherty Study Center,

School of Theology, Claremont University, Claremont, Califomia

(Credit: Robert J. Flaherty / Library and Archives of Canada / PA- 143312) 


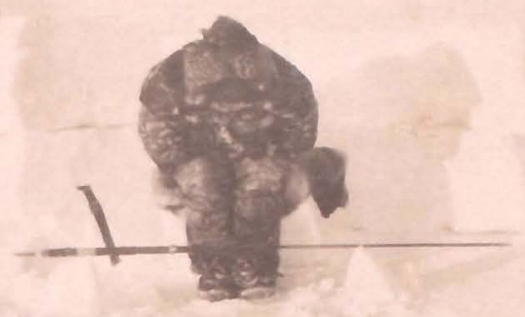

\section{CATALOGUE 12}

\section{AGO accession number: 93/280.9}

Photographer: Robert J. Flaherty (|884-|95 |)

Title name: Unidentified Seated Eskimo over Seal Breathing Hole - with Harpoon (Descriptive, AGO Primary Title, Inscribed on matte)

Date of object: 1910-1916 (Negative date)

Date note: "19/3 P[?]" previous date stated

Medium: Gelatin silver bromide print

Dimensions: Image: Image: $8.8 \times 11.3 \mathrm{~cm}(37 / 16 \times 4$ $7 / 16$ in.); Sheet: $25.3 \times 20.1 \mathrm{~cm}(9 / 5 / 16 \times 7 / 5 / 16$ in. $)$ Inscription: None

\section{Alternate number: AGO ID\# 22139}

Notes: Originally in album that contained 20 photographs; album pages were originally numbered in graphite (as noted by $\mathrm{AGO}$ conservator); there is residual black paper adhered to the verso of the sheet ( u.r., u.l., I.r., I.I.). The album was the donor's possession and was discarded by the AGO; see appendix B.

\section{Related object at AGO: None}

Provenance: Gift of Gordon M. Robb, 1993

Exhibition history: "Robert Flaherty: Camera Studies", AGO, 15 June - 18 September 1994

References (unpublished): The Robert and Frances Study Center, School of Theology. "A Visual Index to the Flaherty Still Photographs: Nanook 2001-2416." Claremont University http://www.cst.edu/flaherty/VIS_INDEX_NANOOK_2001.pdf, page 8, frame 2231.

Related object at LAC: There are two related objects on loan from The Robert and Frances Flaherty Study Center, School of Theology, Claremont University, Claremont, California to LAC.

These object have the same LAC reference numbers: Item number 2231; Other accession number 1979-242 NPC; Copy negative PA- I 4272.

I. [Unidentified person seated with harpoon] Gelatin silver print. Image: $8.9 \times 10.9 \mathrm{~cm}$; Sheet: $9.8 \times 11.7 \mathrm{~cm}$. Inscriptions: (Verso) c: "N (5I2) [?] NIC N223I"; I...: " "985-105" all inscribed in graphite.

Note: (Verso) Black paper glued to photograph.

2. [Unidentified person seated with harpoon] (Figure 10)

Gelatin silver glass lantern slide.

Sheet (glass): $10.1 \times 8.2 \mathrm{~cm}$.

(Fig. 10)

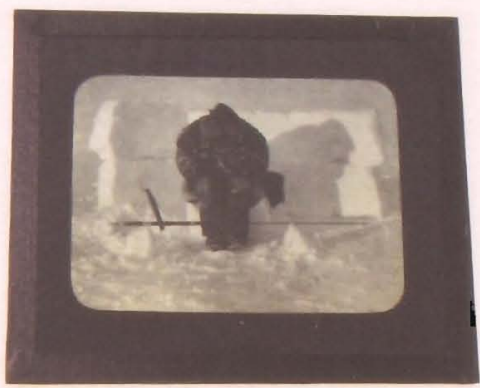

Unidentified Person Seated with Harpoon

Gelatin silver glass lantern slide

On loan from The Robert and Frances Flaherty

Study Center,

School of Theology, Claremont University, Claremont, California

(Credit: Robert J. Flaherty / Library and Archives of Canada / PA- I | 4272) 


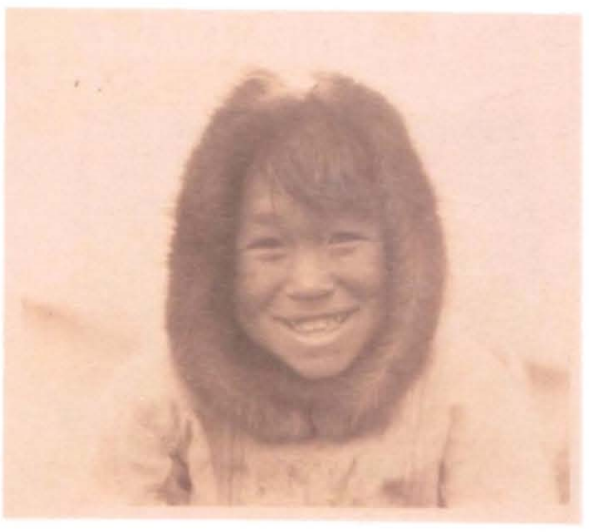

\section{CATALOGUE 13}

AGO accession number: 93/280.9

Photographer: Robert J. Flaherty (| 884-195 |)

Title name: Unidentified Inuit Child (Ungava Peninsula, Quebec) (Descriptive); (Young Eskimo Boy), Baffin Island? (Descriptive, AGO Primary Title, Inscribed on matte)

Date of object: 1910-1914 (Negative date)

Date note: |9|3-1914 date previously part of title. New date taken from LAC website.

Medium: Toned gelatin silver print

Dimensions: Image: Image: $12 \times 14.7 \times \mathrm{cm}(43 / 4 \times 5$ I3/16 In.); Sheet: $20.22 \times 5.2 \mathrm{~cm}(7 / 5 / 16 \times 9$ I5/16 in.) Inscription: None

\section{Alternate number: AGO ID\# 22I 40}

Notes: Originally in album that contained 20 photographs; album pages were originally numbered in graphite (as noted by AGO conservator); there is residual black paper adhered to the verso of the sheet ( u.r., u.I., I.r., I.I.). The album was the donor's possession and was discarded by the AGO; see appendix B.

\section{Related object at AGO: None}

Provenance: Gift of Gordon M. Robb, 1993

\section{Exhibition history: None}

References (unpublished): The Robert and Frances Study Center, School of Theology. "A Visual Index to the Flaherty Still Photographs: Nanook 2001-24I6 and 2417-end." Claremont University http://mmw.cst.edu/ flaherty/NIS_INDEX_NANOOK_2001.pdf, page 5, frame N21 | 4; http://muw.cst.edu/flaherty/VIS_INDEX_NANOOK_2417.pdf, page 2, frame N2429.

Related object at LAC: There are two related objects on loan from The Robert and Frances Flaherty Study Center, School of Theology, Claremont University, Claremont, California to $L A C$.
These objects have different titles and LAC reference numbers.

\section{Unidentified Inuit Child (Figure || and Figure} 12)

Gelatin silver glass plate negative. Image: $9.5 \times 12$ $\mathrm{cm}$ Sheet (glass): $10.1 \times 12.6 \mathrm{~cm}$. Inscriptions: (Verso) l.1.:" "47" crossed out in black inki l.r.: "FN295 G" inscribed in black ink.

Note: Missing corner. LAC reference numbers: Item number 21 14; Other accession number 1979-242 NPC; Copy negative PA-114101.

\section{Unidentified Portrait of Eskimo Boy (Figure 13)} Gelatin silver glass lantern slide. Sheet (glass): 10.1 $\times 8.3 \mathrm{~cm}$. LAC reference numbers: Item number 2429; Other accession number 1979-242 NPC; Copy negative PA- | | 424 |.

(Fig. II) Recto

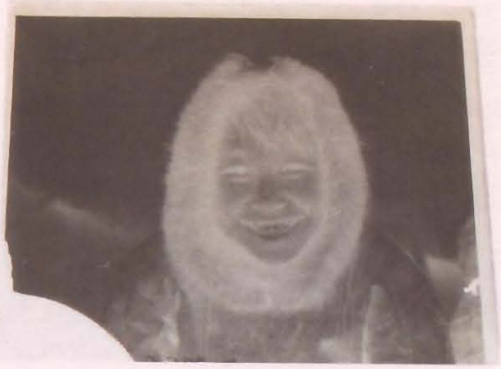

(Fig. 12) Verso

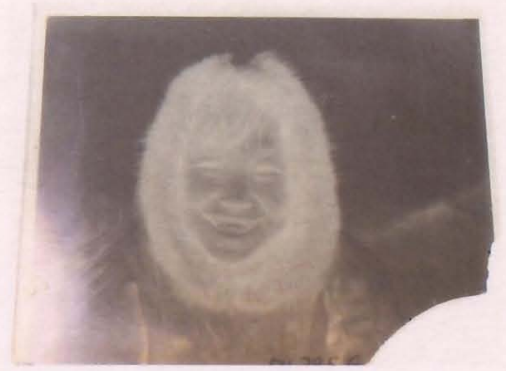

Unidentified Inuit Child

Gelatin silver glass plate negative

LAC on loan from The Robert and Frances Flaherty Study Center, School of Theology,

Claremont University, Claremont, California.

(Credit: Robert J. Flaherty / Library and Archives of Canada / PA-114101) 
(Fig. 13)

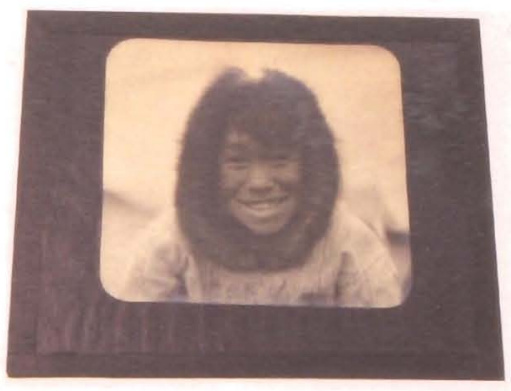

Unidentified Portrait of Eskimo Boy

Gelatin silver glass lantern slide

Sheet (glass): $10.1 \times 8.3 \mathrm{~cm}$

LAC on loan from The Robert and Frances Flaherty Study

Center, School of Theology,

Claremont University, Claremont, California.

(Credit: Rober). Flaherty/ Library and Archives of Canada | PA-1 |424|)

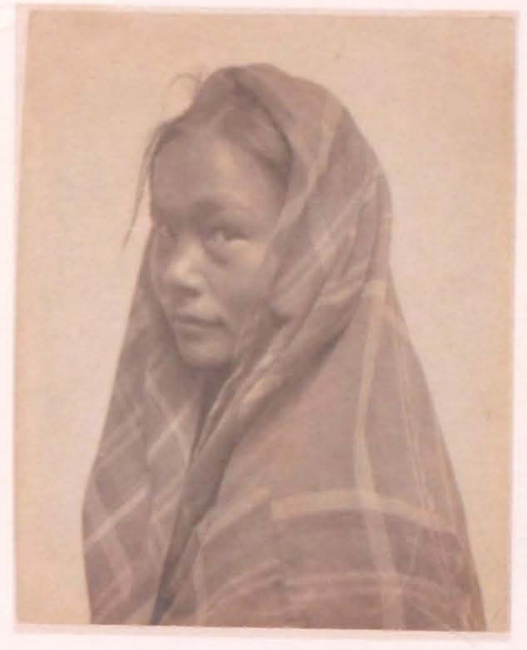

\section{CATALOGUE 14}

AGO accession number: 93/280.1 I

Photographer: Robert J. Flaherty ( $884-195$ |)

Title names: Unidentified (Young Girl with Plaid Shawl), Ungava Peninsula (Descriptive, AGO Primary Title, Inscribed on matte)

Date of object: 1910-1912 (Negative date)

Date note: Date previously part of title. Date derives from Independent researcher, Janet Dewan's research for the Flaherty works at AGO in 1994.

Medium: Gelatin silver bromide print

Dimensions: Image: $25.3 \times 20.2 \mathrm{~cm}(9$ 15/16 $\times 7$ 15/16 in.)

Sheet: $25.3 \times 20.2 \mathrm{~cm}(9 / 5 / 16 \times 7 / 15 / 16 \mathrm{in}$.

Inscription: None

Alternate number: AGOID\# 22141

Notes: Originally in album that contained 20 photographs; album pages were originally numbered in graphite (as noted by AGO conservator); there is residual black paper adhered to the verso of the sheet ( u.r., u.l., I.r., I.I.). The album was the donor's possession and was discarded by the AGO; see appendix $\mathrm{B}$.

Related object at AGO: None

Provenance: Gift of Gordon M. Robb, 1993

Exhibition history: "Robert Flaherty: Camera Studies", AGO, 15 June 1994 - 18 September 1994

References (published): Birnie Danzker, Jo-Anne. Robert Flaherty, Photographer / Filmmaker:The Inuit 1 10-1922. Vancouver, British Columbia:Vancouver Art Gallery, 1979, pages 33, 85 (cat. 27). 
References (unpublished): The Robert and Frances Study Center, School of Theology. "A Visual index to the Flaherty Still Photographs: Nanook 24I7-end." Claremont University http://umw.cst.edu/flaherty/NIS_INDEX_NANOOK_2417.pdf, page 3, frame N2463.

Related object at LAC: Unidentified (Indian?) Girl Gelatin silver print on matte paper. Image: $15.2 \times 11.1 \mathrm{~cm}$; Sheet: $15.2 \times 11.1 \mathrm{~cm}$. Inscriptions: (Recto) I.c.:" No neg found"; I.r.:. "C" inscribed in blue graphite. (Verso) u.p.: "C/No neg found" inscribed in blue graphite; c.: "N2463" inscribed in graphite; I.I.: "| 985-105" inscribed in graphite; I.c.: "PA-| 4372| " inscribed in graphite.

Note: Image is out of focus. (Verso) Black paper residue adhered to sheet. LAC reference numbers: Item number 2463; Other accession number 1985-105 NPC; PA-143721. On loan from The Robert and Frances Flaherty Study Center at Claremont School of Theology.

There is also prints in the collection of Thunder Bay Historical Museum and the Royal Ontario Museum, as described and illustrated in the catalogue by Birnie Danzker, page 85 (cat.27), cited in References (published).

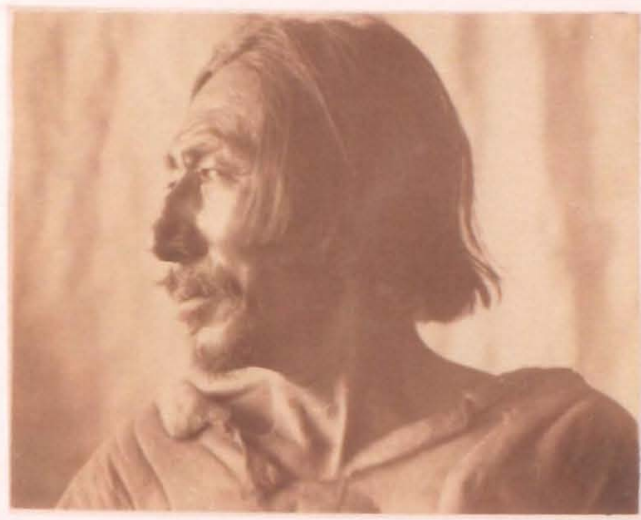

\section{CATALOGUE 15}

AGO accession number: 93/280.12

Photographer: Robert J. Flaherty (| 884-195 |)

Title names: Unidentified (Man in Profile), Fort Chimo? (Descriptive, AGO Primary Title, Inscribed on matte)

Date of object: 1912-1913 (Negative date)

Date note: Date previously part of title. Date derives from Independent researcher, Janet Dewan's research for the Flaherty works at AGO in 1994.

Medium: Gelatin silver bromide print

Dimensions: Image: $15.9 \times 20.2 \mathrm{~cm}(6$ I/4 $\times 7$ 15/16 in.)

Sheet: $15.9 \times 20.2 \mathrm{~cm}(61 / 4 \times 7 / 5 / 16 \mathrm{in}$. $)$

Inscription: None

Alternate number: AGOID\# 22142

Notes: Originally in album that contained 20 photographs; album pages were originally numbered in graphite (as noted by AGO conservator); there is residual black paper adhered to the verso of the sheet ( u.r., u.l., I.r., I.I.). The album was the donor's possession and was discarded by the AGO; see appendix B.

Related object at AGO: None

Provenance: Gift of Gordon M. Robb, 1993

Exhibition history: "Robert Flaherty: Camera Studies", AGO, 15 June 1994 - 18 September 1994

References (unpublished): The Robert and Frances Study Center, School of Theology. "A Visual Index to the Flaherty Still Photographs: Nanook 2417- end." Claremont University http://umw.cst.edu/flaherty/VIS INDEX_NANOOK_2417.pdf, page 3, frame N2474. 
Related object at LAC: There are two related objects on loan from The Robert and Frances Flaherty Study Center, School of Theology, Claremont University, Claremont, California to LAC. These object have the same title and LAC reference numbers: Item number 2474; Other accession number 1985-105 NPC; Copy negative PA- 143717

1. Unidentified Portrait of Man, most likely Naskapi Indian] (Figure 14)

Gelatin silver print (on semi-glossy paper) Image: 14 × $18.4 \mathrm{~cm}$; Sheet: 14.6 × $18.9 \mathrm{~cm}$.

Inscription: (Recto) u.r.: "N2474" in graphite; I.r:." No Neg Found" in blue. (Verso) c.l.: "C/No Neg Found" in blue graphite; I.I.:" $1985-105$ " in graphite; I.c.: "(PA143717)" in graphite.

Note: Could possibly be a photogravure according LAC archivist. Also image is reversed.

2. Unidentified Portrait of Man, most likely Naskapi Indian (Figure 15)

Gelatin silver print (hand-coloured) ]. Image: $16.3 \times$ $21.4 \mathrm{~cm}$; Sheet: $16.3 \times 21.4 \mathrm{~cm}$.

Inscriptions: (Verso) u.l.: "C' inscribed in blue graphite; u.r.: "N2474" in graphite; c.l.: "No Neg found" in blue graphite; 1.1.:" I985-105"' in graphite; I.c.:" PA143717" in graphite.

Note: Could possibly be a photogravure according LAC archivist. Also image is reversed.

(Fig. 14)

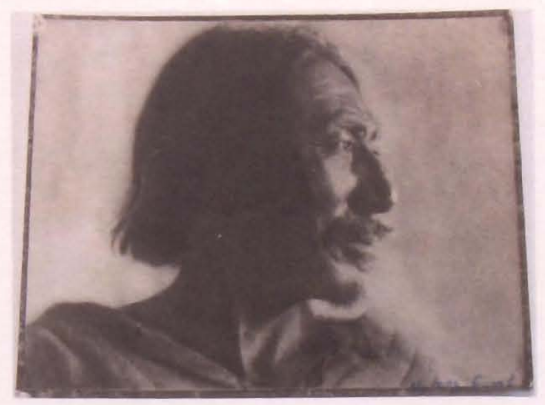

Unidentified Portrait of Man, Most Likely Naskapi Indian Gelatin silver print (on semi-glossy paper)

On loan from The Robert and Frances Flaherty Study Center, School of Theology, Claremont University,

Claremont, California

(Credit: Robert J. Flaherty / Library and Archives of Canada / PA-143717)

\section{(Fig. 15)}

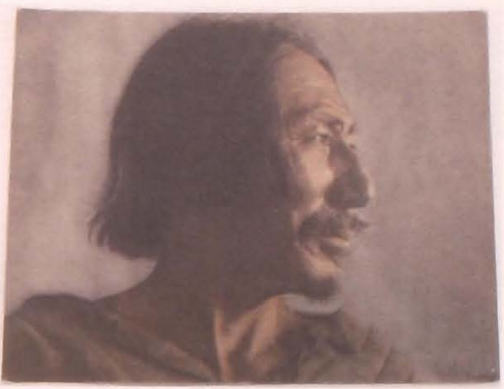

Unidentified Portrait of Man, Most Likely Naskapi Indian Gelatin silver print (hand-coloured)

On loan from The Robert and Frances Flaherty Study Center,

School of Theology, Claremont University, Claremont, California

(Credit: Robert J. Flaherty / Library and Archives of Canada / PA-143717) 


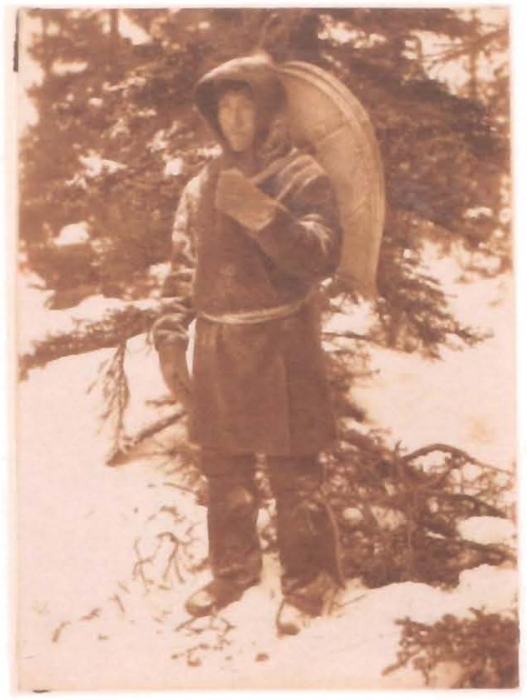

\section{CATALOGUE 16}

AGO accession number: $93 / 280.13$

Photographer: Robert J. Flaherty (|884-195|)

Title names: Unidentified Naskapi or Montagnais Indian with snowshoes on his back, Fort Chimo (Descriptive); Cree on foot with snowshoes (Descriptive, AGO Primary Title, Inscribed on matte)

Title note: Previous title: Cree on foot with snowshoes. First title taken from LAC website

Date of object: 1912 (Negative date)

Date note: "Before 1912" date previously part of title. New date taken from LAC website.

Medium: Toned gelatin silver bromide print

Dimensions: Image: $25.1 \times 18.3 \times \mathrm{cm}(97 / 8 \times 73 / 16$ in.) Sheet: $25.1 \times 18.3 \mathrm{~cm}(97 / 8 \times 73 / 16$ in. $)$

Inscription: None

Alternate number: AGOID \# 22143

Notes: Originally in album that contained 20 photographs; album pages were originally numbered in graphite (as noted by AGO conservator); there is residual black paper adhered to the verso of the sheet ( u.r., u.l., I.r., l.I.). The album was the donor's possession and was discarded by the AGO; see appendix B.

Related object at AGO: None

Provenance: Gift of Gordon M. Robb, 1993

Exhibition history: None
References (unpublished): The Robert and Frances Study Center, School of Theology. "A Visual Index to the Flaherty Still Photographs: Nanook 200 I-24I6." Claremont University http://www.cst.edu/flaherty/VIS_ INDEX_NANOOK_2001.pdf, page 13, frame N2378.

Related objects at LAC: Unidentified Naskapi or Montagnais Indian with Snowshoes on his Back Gelatin silver print on matte paper. Image: $15.7 \times 10 \mathrm{~cm}$; Sheet: $16.8 \times 11.1 \mathrm{~cm}$. Note: (Verso) Black paper residue adhered to sheet. LAC reference numbers: Item number 2378; Other accession number 1985-105 NPC; Copy negative PA-143721. On loan from The Robert and Frances Flaherty Study Center, School of Theology, Claremont University, Claremont, California. 


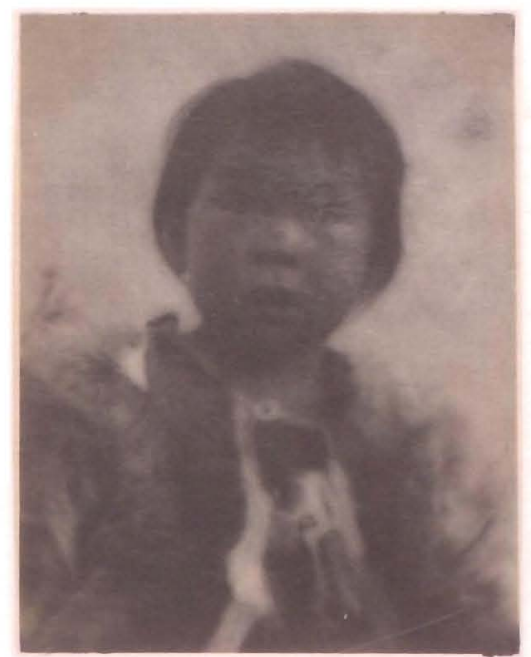

\section{CATALOGUE 17}

AGO accession number:93/280.14

Photographer: Robert J. Flaherty (|884- |95|)

Title name: Unidentified (Child), Baffin Island (Descriptive, AGO Primary Title, Inscribed on matte)

Date of object: 19/3-19/4 (Negative date)

Date note: Date previously part of title. Date derives from Independent researcher, Janet Dewan's research for the Flaherty works at AGO in 1994.

Medium: Gelatin silver bromide print

Dimensions: Image: $23.8 \times 18.5 \mathrm{~cm}(93 / 8 \times 75 / 16$ in.) Sheet: $23.8 \times 18.5 \mathrm{~cm}(93 / 8 \times 75 / 16 \mathrm{in}$. $)$

Inscription: None

\section{Alternate number: AGO ID\# 22144}

Notes: Originally in album that contained 20 photographs; album pages were originally numbered in graphite (as noted by AGO conservator); there is residual black paper adhered to the verso of the sheet ( u.r., u.l., I.r., I.I.). The album was the donor's possession and was discarded by the AGO; see appendix B.

\section{Related object at AGO: None}

Provenance: Gift of Gordon M. Robb, 1993

Exhibition history: "Robert Flaherty: Camera Studies", AGO, 15 June 1994 - 18 September 1994

References (unpublished): The Robert and Frances Study Center, School of Theology. "A Visual Index to the Flaherty Still Photographs: Nanook 2417- end." Claremont University http://wmw.cst.edu/flaherty/VIS_INDEX_NANOOK_2417.pdf, page 9, frame N2663
Related object at LAC: Unidentified Inuit Child (Figure 16) Gelatin silver print on glossy paper. Image: $9.4 \times 7.1 \mathrm{~cm}$; sheet: $9.4 \times 7.1 \mathrm{~cm}$. Inscriptions: (Verso) u.c.: "N (265)/ NIC/ N2663/566" all inscribed in graphite; 1.I.." $1985-105$ " inscribed in graphite; I.c.: PA- 147870.

Note: (Verso) residual brown paper glued to photograph. LAC reference numbers: Item number 2663: Other accession number: 1985- 105 NPC; Copy negative: PA-147870. On loan from The Robert and Frances Flaherty Study Center, School of Theology, Claremont University, Claremont, California.

(Fig. 16)

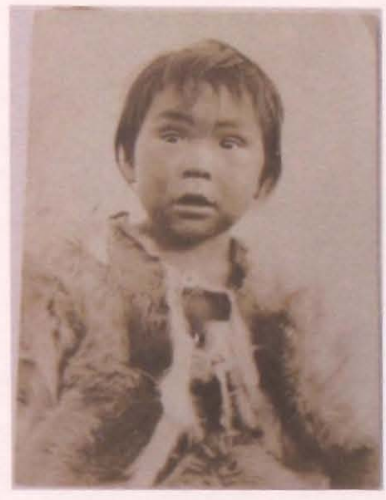

Unidentified Inuit Child

Gelatin silver print

On loan from The Robert and Frances Flaherty Study Center,

School of Theology, Claremont University, Claremont, California

(Credit: Robert J. Flaherty / Library and Archives of Canada / PA- |47870) 


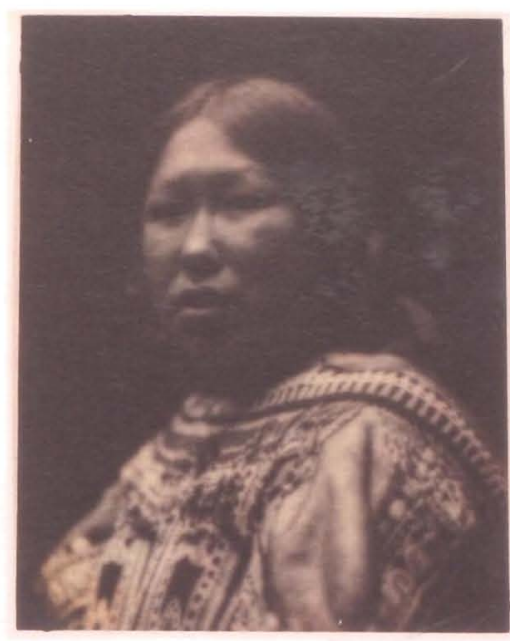

\section{CATALOGUE 18}

AGO accession number: $93 / 280.15$

Photographer: Robert J. Flaherty (1884-1951)

Title name: Unidentified (Woman) Chesterfield Inlet (Descriptive, AGO Primary Title, Inscribed on matte)

Date of object: 1912 (Negative date)

Date note: Date previously part of title. Date derives from Independent researcher, Janet Dewan's research for the Flaherty works at AGO in 1994.

Medium: Gelatin silver bromide print

Dimensions: Image: $23.8 \times 18.9 \mathrm{~cm}(93 / 8 \times 77 / 16 \mathrm{in}$.) Sheet: $23.8 \times 18.9 \mathrm{~cm}(93 / 8 \times 77 / 16 \mathrm{in}$. $)$

Inscription: None

Alternate number: AGO ID\# 22145; Photo Negative Number N-9508

Notes: Originally in album that contained 20 photographs; album pages were originally numbered in graphite (as noted by AGO conservator); there is residual black paper adhered to the verso of the sheet ( u.r., u.l., I.r., I.I.). The album was the donor's possession and was discarded by the AGO; see appendix B.

Related object at AGO: None

Provenance: Gift of Gordon M. Robb, 1993

Exhibition history: "Robert Flaherty: Camera Studies", AGO, 15 June 1994 - 18 September 1994

References (published): Birnie Danzker, Jo-Anne. Robert Flaherty, Photographer / Filmmaker: The Inuit I 10-1922.Vancouver, British Columbia:Vancouver Art Gallery, 1979 ,
References (unpublished): The Robert and Frances Study Center, School of Theology. "A Visual Index to the Flaherty Still Photographs: Nanook 000 I-0383." Claremont University http://www.cst.edu/flaherty/VIS_ INDEX_NANOOK_000I.pdf, page 8, frame N2 4.

Related objects at LAC: There are two related objects on loan from The Robert and Frances Flaherty Study Center, School of Theology, Claremont University, Claremont, California to LAC. These object have the same $L A C$ reference numbers: Item number 0214 ; Other accession number 1985- 105 NPC; Copy negative PA147870 .

\section{I. [Unidentified Woman]}

Gelatin silver print.

Image: $8.2 \times 6 \mathrm{~cm}$; Sheet: $8.2 \times 6 \mathrm{~cm}$. Inscriptions: (Verso) u.c.: "N -25 I" inscribed in graphite; c: "N2/4/ (cropped) 94[?] / 294" all inscribed in graphite; I.... "1985-105".

Note: (Verso) Residual brown paper glued to photograph.

\section{2. [Unidentified Woman] (Figure 17)}

Gelatin silver glass lantern slide.

Sheet (glass): $9.2 \times 10.7 \mathrm{~cm}$.

Note: Image of subject's face is in-focus.

(Fig. 17)

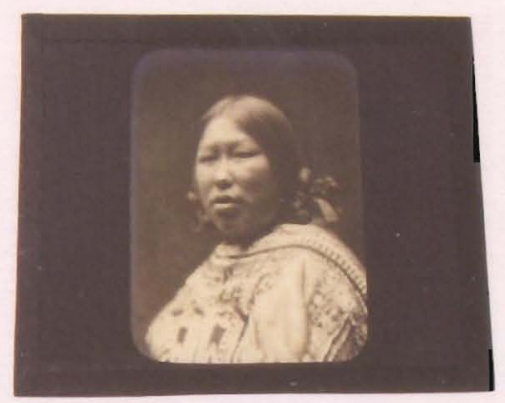

Unidentified Woman

Gelatin silver glass lantern slide

On loan from The Robert and Frances Flaherty Study Center,

School of Theology, Claremont University, Claremont, California.

(Credit: Robert ). Flaherty / Library and Archives of Canada / PA- | 47870) 


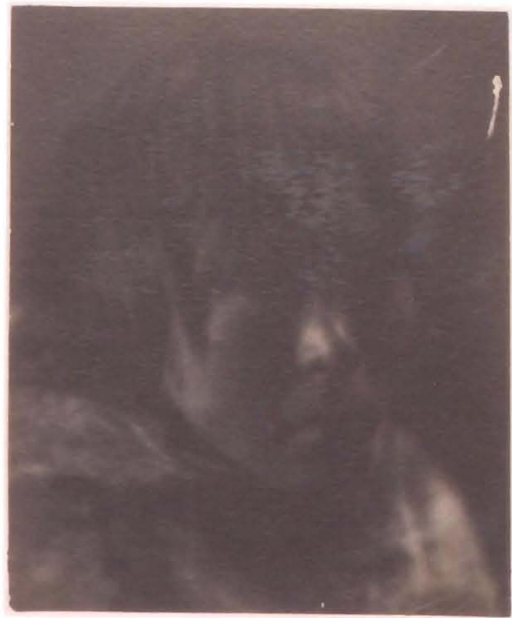

\section{CATALOGUE 19}

AGO accession number: 93/280.16

Photographer: Robert J. Flaherty (1884-1951)

Title names: Unidentified (Ezechiak), Baffin Island (Descriptive, AGO Primary Title, Inscribed on matte)

Date of object: 1913-1914 (Negative date)

Date note: Date previously part of title. Date derives from Independent researcher, Janet Dewan's research for the Flaherty works at AGO in 1994.

Medium: Gelatin silver bromide print

Dimensions: Image: $24 \times 19.8 \mathrm{~cm}(97 / 16 \times 7 / 3 / 16 \times$ in.) Sheet: $24 \times 19.8 \mathrm{~cm}(97 / 16 \times 7 / 3 / 16 \times$ in. $)$

Inscription: None

Alternate number: AGOID \# 22146; Photo Negative Number N9503

Notes: Originally in album that contained 20 photographs; album pages were originally numbered in graphite (as noted by AGO conservator); there is residual black paper adhered to the verso of the sheet ( u.r., u.l., I.r., I.I.). The album was the donor's possession and was discarded by the AGO; see appendix B.

Related object at AGO: None

Provenance: Gift of Gordon M. Robb, 1993

Exhibition history: "Robert Flaherty: Camera Studies", AGO, 15 June - 18 September 1994

References (unpublished): The Robert and Frances Study Center, School of Theology. "A Visual Index to the Flaherty Still Photographs: Nanook 2417- end." Claremont University http://wmw.cst.edu/flaherty/ VIS_INDEX_NANOOK_2417.pdf, page 4, frame N2502 [partially visible].
Related object at LAC: Avaleeneatok, One of Flaherty's Helpers. LAC reference numbers: Item number: 2502; Other accession number: 1985-105 NPC; Copy negative: PA-147369. on loan from The Robert and Frances Flaherty Study Center, School of Theology, Claremont University, Claremont, California [Photograph was not found in April 2010]. 


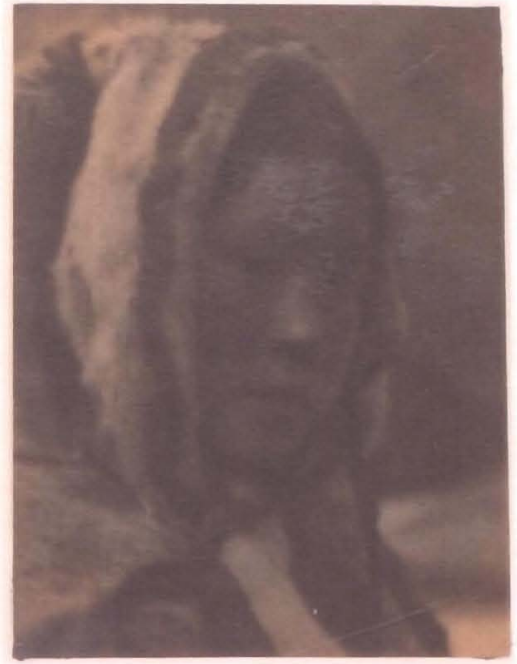

\section{CATALOGUE 20}

AGO accession number: 93/280.17

Photographer: Robert J. Flaherty (|884-195 |)

Title names: Unidentified (Woman in Hood), Baffin Island (Descriptive, AGO Primary Title, Inscribed on matte)

Date of object: 1913-1914 (Negative date)

Date note: Date previously part of title. Date derives from Independent researcher, Janet Dewan's research for the Flaherty works at AGO in 1994.

Medium: Gelatin silver bromide print

Dimensions: Image: $24 \times 19.2 \mathrm{~cm}(97 / 16 \times 7 / 3 / 16 \mathrm{in}$. Sheet: $24 \times 19.2 \mathrm{~cm}(97 / 16 \times 7 / 3 / 16 \mathrm{in}$. $)$

Inscription: None

Alternate number: AGOID \# 22147

Notes: Originally in album that contained 20 photographs; album pages were originally numbered in graphite (as noted by AGO conservator); there is residual black paper adhered to the verso of the sheet ( u.r., u.l., I.r., I.I.). The album was the donor's possession and was discarded by the AGO; see appendix B.

\section{Related object at AGO: None}

Provenance: Gift of Gordon M. Robb, 1993

Exhibition history: "Robert Flaherty: Camera Studies", AGO, 15 June - 18 September 1994

References (unpublished): The Robert and Frances Study Center, School of Theology. "A Visual Index to the Flaherty Still Photographs: Nanook 2417-end." Claremont University http://mww.cst.edu/flaherty/VIS_INDEX_NANOOK_2417.pdf, page 5, frame N2522.
Related object at LAC: Unidentified Young Inuit Woman

Gelatin silver print on glossy paper. Image: $15.9 \times 9 \mathrm{~cm}$ Sheet: $15.9 \times 9 \mathrm{~cm}$.

Inscriptions: (Recto) I.r.:."C"; I.c.: "No neg found" all inscribed in blue graphite. (Verso) u.r.: "N2522 / PA147384 " inscribed in graphite; u.c.: "No neg [found?]" inscribed in blue graphite; c: " 819 " inscribed in graphite; I.1.." $1985-105$ " inscribed in graphite.

Note: (Verso) Residual glue and brown paper on photograph. LAC reference numbers: Item number 2522; Other accession number 1985-105; Copy negative PA-147384. On loan from The Robert and Frances Flaherty Study Center, School of Theology, Claremont University, Claremont, California. 


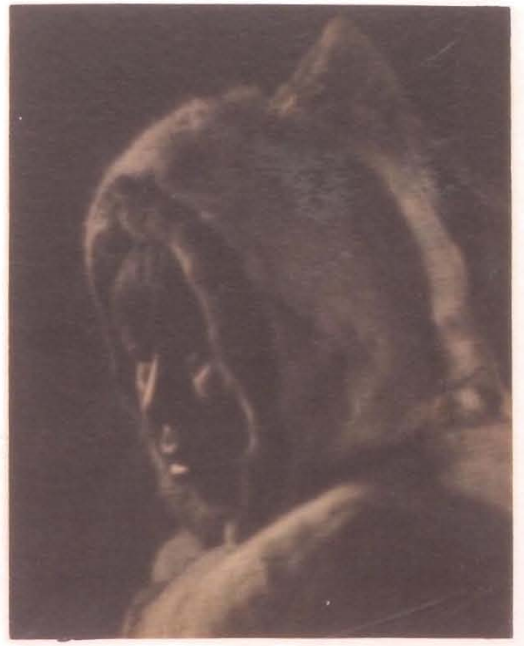

\section{CATALOGUE 21}

AGO accession number: 93/280.18

Photographer: Robert J. Flaherty (|884-195|)

Title names: Sapa? (In Fur Hood), Baffin Island (Descriptive, AGO Primary Title, Inscribed on matte)

Date of object: 1910-1916 (Negative date)

Date note: "c. 1913-1914" previously part of title. Date derives from Independent researcher, Janet Dewan's research for the Flaherty works at AGO in 1994.

Medium: Gelatin silver bromide print

Dimensions: Image: $23.6 \times 18.6 \mathrm{~cm}(9 / 5 / 16 \times 75 / 16$ in.) Sheet: $23.6 \times 18.6 \mathrm{~cm}(9 / 5 / 16 \times 75 / 16 \mathrm{in}$.)

Inscription: None

Alternate number: AGOID \# 22148

Notes: Originally in album that contained 20 photographs; album pages were originally numbered in graphite (as noted by AGO conservator); there is residual black paper adhered to the verso of the sheet ( u.r., u.l., I.r., I.I.). The album was the donor's possession and was discarded by the AGO; see appendix B.

Related object at AGO: None

Provenance: Gift of Gordon M. Robb, 1993

Exhibition history: None

References: None

Related object at LAC: None

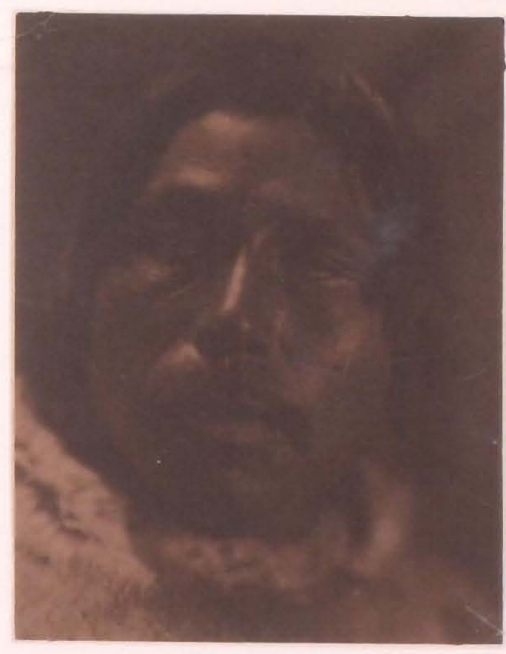

CATALOGUE 22

AGO accession number: 93/280.19

Photographer: Robert J. Flaherty ( 1884-1951)

Title names: Tooktoo (The Deer), Southern Baffin Island (Descriptive, AGO Primary Title, Inscribed on matte)

Date of object: 1913-1914 (Negative date)

Date note: Date previously part of title. Date derives from Independent researcher, Janet Dewan's research for the Flaherty works at AGO in 1994

Medium: Gelatin silver bromide print

Dimensions: Image: $25.3 \times 20 \mathrm{~cm}(9 / 5 / 16 \times 77 / 8 \mathrm{in}$.) Sheet: $25.3 \times 20 \mathrm{~cm}(9 / 5 / 16 \times 77 / 8 \mathrm{in}$.)

Inscription: None

Alternate number: AGOID \# 22149

Notes: Originally in album that contained 20 photographs; album pages were originally numbered in graphite (as noted by AGO conservator); there is residual black paper adhered to the verso of the sheet ( u.r., u.l., I.r., I.I.). The album was the donor's possession and was discarded by the AGO; see appendix B.

Related object at AGO: Catalogue 41 (AGO Acc. No. 92/89.9); Catalogue 4I (AGO Acc. No. 2007/159.1; Catalogue (same man in these images but is in a different pose)

Provenance: Gift of Gordon M. Robb, 1993

Exhibition history: None

References: None

Related object at LAC: None 


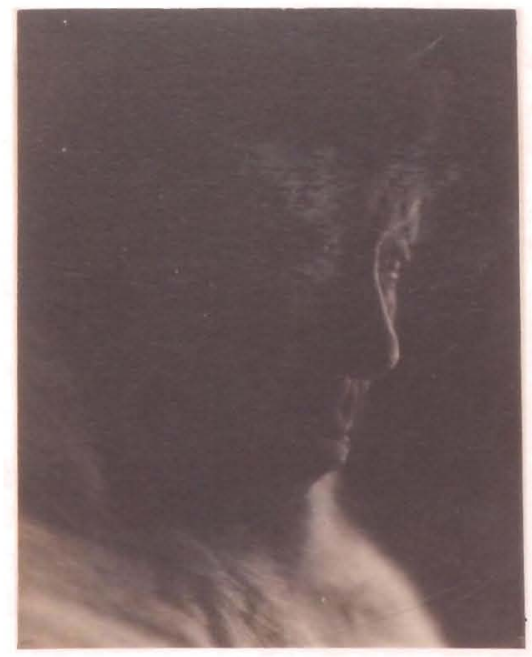

\section{CATALOGUE 23}

AGO accession number: 93/280.20

Photographer: Robert J. Flaherty (1884-1951)

Title names: Unidentified (Old Man), Baffin Island (Descriptive, AGO Primary Title, Inscribed on matte)

Date of object: 1913-1914 (Negative date)

Date note: Date previously part of title. Date derives from Independent researcher, Janet Dewan's research for the Flaherty works at AGO in 1994.

Medium: Gelatin silver bromide print

Dimensions: Image: $25.3 \times 17.8 \mathrm{~cm}(9 / 5 / 16 \times 7$ in. $)$

Sheet: $25.3 \times 17.8 \mathrm{~cm}(9 / 5 / 16 \times 7$ in. $)$

Inscription: None

Alternate number: AGOID \# 22150

Notes: Originally in album that contained 20 photographs; album pages were originally numbered in graphite (as noted by AGO conservator); there is residual black paper adhered to the verso of the sheet ( u.r., u.l., I.r., I.I.). The album was the donor's possession and was discarded by the AGO; see appendix B.

\section{Related object at AGO: None}

Provenance: Gift of Gordon M. Robb, 1993

Exhibition history: None

References: None

Related object at LAC: None

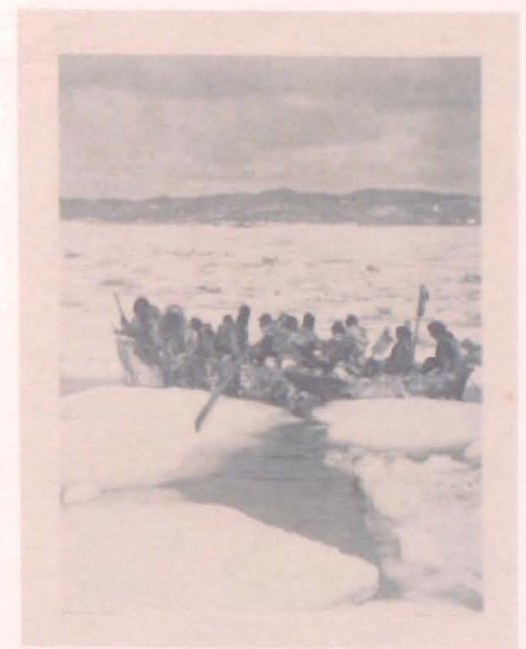

\section{CATALOGUE 24}

AGO accession number: $92 / 89.1$

Photographer: Robert J. Flaherty (1884-1951)

Title names: Eskimo Omiak in the Spring (Imprinted, Published, AGO Primary Title)

Date of object: 1920-1921 (Negative date); 1922 (Published date)

Medium: Photogravure

Dimensions: Image: $21.3 \times 16.5 \mathrm{~cm}(83 / 8 \times 6.5$ in. $)$ Sheet: $47 \times 33 \mathrm{~cm}(181 / 2 \times 13$ in. $)$

Portfolio: Camera Studies of the Far North

Constituents (object related): Publisher: G.P. Putnam's Sons, New York; Image copyright holder: Revillon Frères, New York; Photogravure printer: The American Gravure Company, N.Y.C.

Inscription: (Recto) c.r.:" ROBERT J. FLAHERTY, F.R.G.S."; c.l.:"c (circled) REVILLON FRERES, N.Y." (Imprinted); I.I.: "ESKIMO OMIAK INTHE SPRING" (Imprinted)

Alternate number: AGOID \# 20602

Related object at AGO: None

Provenance: Gift of Susan Osborn, 1992

Exhibition history: "Robert Flaherty: Camera Studies", AGO, 15 June - 18 September 1994

References (published): Flaherty, Robert J. (In collaboration with Frances Hubbard Flaherty). My Eskimo Friends. Garden City and New York: Doubleday, Page \& Company, 1924, page 34 (illustration). 
Birnie Danzker, Jo-Anne. Robert Flaherty, Photographer / Filmmaker:The Inuit I 10-1922.Vancouver, British Columbia:Vancouver Art Gallery, 1979, page 58 (illustration - appears slightly cropped), 89 (catalogue 99, see also catalogue 97).

References (unpublished): The Robert and Frances Study Center, School of Theology. "A Visual Index to the Flaherty Still Photographs: Nanook 000 I-0383." Claremont University http://www.cst.edu/flahertyNIS_INDEX_NANOOK_000I.pdf, page 10, frame N304

Related objects at LAC: There are four related objects on loan from The Robert and Frances Flaherty Study Center at School of Theology, Claremont University, Claremont, California to LAC. All have the same title and $L A C$ reference numbers. $L A C$ reference numbers: Item number 0304; other accession number 1979-242 NPC; copy negative PA-121990.

I. Inuit Omiak (boat) in Spring (Figure 18 and Figure 19) Gelatin silver print with tissue overlay. Image: $25.4 \times 19.4 \mathrm{~cm}$; Sheet: $27 \times 20.7 \mathrm{~cm}$

Inscriptions: (Verso) u.c: [llleg., numbers crossed out]; N304 (Inscribed in graphite); I full[?] (Inscribed in red); u.r:: 26[?]//8//2 (Inscribed in graphite); E8598[?] (stamped in red); c: Nanook of the North (underlined) (inscribed in graphite); c.r.: 3438/60-49[?]/[lleg.]; 5 (circled) (inscribed in red); I.I.: I.r.: PROPERTY OF/ RETURNTO/ LIBRARY/ PHOTOPLAY MAGAZINE (Stamped in red); 1985-105 (Inscribed in graphite).

\section{Inuit Omiak (boat) in Spring}

Gelatin silver print

Image: $35 \times 27.5 \mathrm{~cm}$; Sheet: $35.3 \times 28 \mathrm{~cm}$

\section{Inuit Omiak (boat) in Spring}

Gelatin silver print Image: $25.4 \times 20.3 \mathrm{~cm}$; Sheet: $25.4 \times 20.3 \mathrm{~cm}$. Inscriptions: (Recto) I.r.: "NPI Ark[?] 4". (Verso) I.r.: "Eskimo Omiak in Spring" inscribed with graphite.

4. Inuit Omiak (boat) in Spring

Gelatin silver print mounted on board

Image: $34.3 \times 25.3 \mathrm{~cm}$; Sheet: $34.3 \times 25.3 \mathrm{~cm}$;

Mount: $34.3 \times 25.3 \mathrm{~cm}$
(Fig. 18) Recto

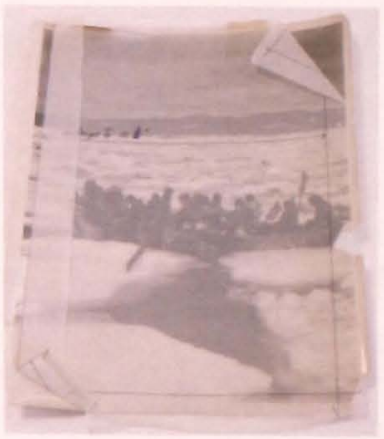

(Fig. 19) Verso

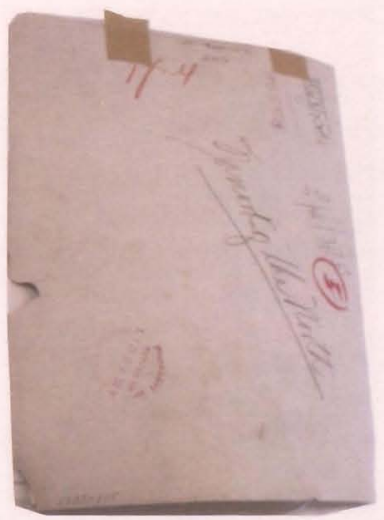

Inuit Omiak (boat) in Spring

Gelatin silver print with overlay

LAC on loan from The Robert and Frances Flaherty

Study Center, School of Theology,

Claremont University, Claremont, California.

Credit: Robert J. Flaherty / Library and Archives of Canada / PA-121990) 


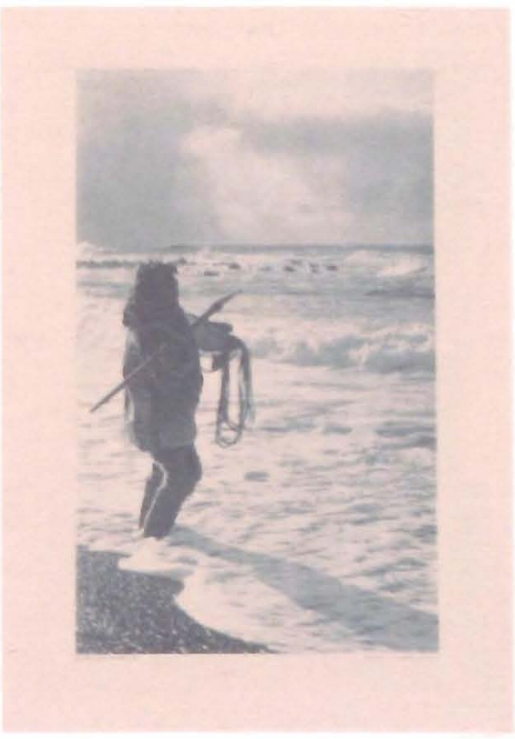

\section{CATALOGUE 25}

AGO accession number: $92 / 89.2$

Photographer: Robert J. Flaherty (| 884-1951)

Title names: The Walrus Hunter (Imprinted, Published title); (Hunter) from Nanook Studies (Descriptive title, AGO Primary title, Inscribed on matte)

Date of object: 1920-1921 (Negative date);

1922 (Published date)

Medium: Photogravure

Dimensions: Image: $21.4 \times 13.2 \mathrm{~cm}(87 / 16 \times 53 / 16$ in. $)$ Sheet: $49.5 \times 32 \mathrm{~cm}(191 / 2 \times 125 / 8 \mathrm{in}$.

Portfolio: Camera Studies of the Far North

Constituents (object related): Publisher: G.P. Putnam's Sons, New York; Image copyright holder: Revillon Frères, New York; Photogravure printer:The American Gravure Company, N.Y.C.

Inscription: (Recto) c.r.: "ROBERT J. FLAHERTY, F.R.G.S." (Imprinted); c.l.." "c (circled) REVILLON FRERES, N.Y." (Imprinted)

\section{Alternate number: AGOID \# 20770}

Notes: Label with title (Imprinted) "The Walrus Hunter" has been removed.

\section{Related object at AGO: None}

Provenance: Gift of Susan Osborn, 1992

Exhibition history: "Robert Flaherty: Camera Studies", AGO, 15 June - 18 September 1994
References (published): Flaherty, Robert J. (In collaboration with Frances Hubbard Flaherty). My Eskimo Friends. Garden City and New York: Doubleday, Page \& Company, 1924, page II 4 (illustration).

References (unpublished): The Robert and Frances Study Center, School of Theology. "A Visual Index to the Flaherty Still Photographs: Nanook O00 I-0383." Claremont University http://www.cst.edu/flaherty/ VIS_INDEX_NANOOK_000I.pdf, page 9, frame N26.

Related objects at LAC: There are two related objects on loan from The Robert and Frances Flaherty Study Center at School of Theology, Claremont University, Claremont, California to LAC. All have the same title and $L A C$ reference numbers. $L A C$ reference numbers: Item number 0261 ; other accession number 1985-105 NPC; copy negative PA-1 43420.

1.The Walrus Hunter from "Nanook of the North" Photogravure. Image: $21.8 \times 13.2 \mathrm{~cm}$; Sheet: $55.5 \times$ $33.3 \mathrm{~cm}$. Inscriptions: (Recto) c.r.: "ROBERT J. FLAHERTY, F.R.G.S."; c.l.:"c (circled) REVILLON FRERES, N.Y.'; I.I.: "THEWALRUS HUNTER".

2. The Walrus Hunter from "Nanook of the North" (Figure 20)

Gelatin silver print. Image: $21.9 \times 13.3 \mathrm{~cm} ; 25.8 \times 20.3$ cm. Inscriptions: (Recto) I.r:. "NPI ART 3" (Imprinted); (Verso) u.r.: "N26|"; I.l.:"|985-105"; I.r.: "PA-143420" (all inscribed in graphite).

(Fig. 20)

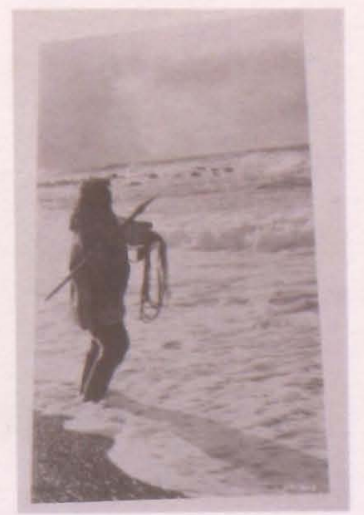

The Walrus Hunter from "Nanook of the North"

Gelatin silver print

LAC on loan from The Robert and Frances Flaherty Study

Center, School of Theology,

Claremont University, Claremont, California.

Credit: Robert J. Flaherty / Library and Archives of Canada / PA-143420) 


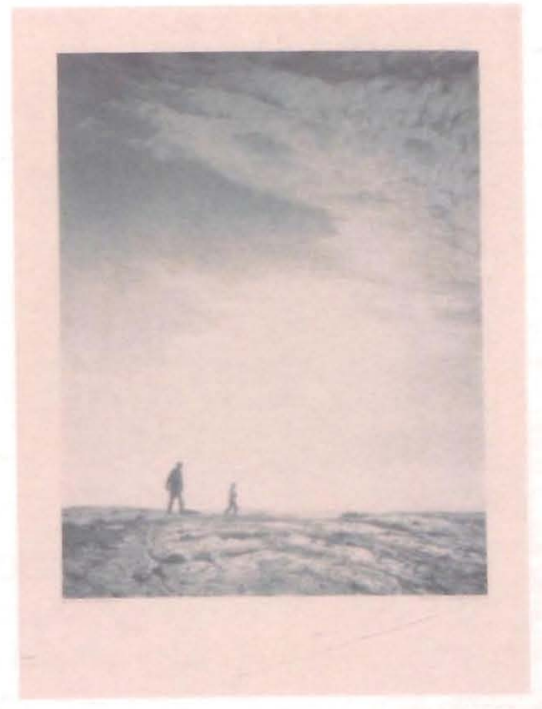

\section{CATALOGUE 26}

AGO accession number: $92 / 89.3$

Photographer: Robert J. Flaherty (1884-1951)

Title names: The Barren Lands, Northern Ungava (Imprinted, Published title, AGO Primary title; (Two Figures) from Nanook Studies (Inscribed on matte)

Date of object: 1910-1916 (Negative date);

1922 (Published date)

Medium: Photogravure

Dimensions: Image: $21.51 \times 6.7 \mathrm{~cm}(87 / 16 \times 69 / 16 \mathrm{in}$. $)$ Sheet: $49.5 \times 32.5 \mathrm{~cm}(191 / 2 \times 1213 / 16 \mathrm{in}$. $)$

Portfolio: Camera Studies of the Far North

Constituents (object related): Publisher: G.P. Putnam's Sons, New York; Image copyright holder: Revillon Frères, New York; Photogravure printer:The American Gravure Company, N.Y.C.

Inscription: (Recto) c.r.: "ROBERT J. FLAHERTY, F.R.G.S." (Imprinted); c.l.: "c (circled) REVILLON FRERES, N.Y.' (Imprinted)

Alternate number: AGOID \# 2077I

Notes: Label with title (Imprinted) "The Barren Lands, Northern Ungava" has been removed.

\section{Related object at AGO: None}

Provenance: Gift of Susan Osborn, 1992

Exhibition history: "Robert Flaherty: Camera Studies", AGO, 15 June - 18 September 1994
References (published): Flaherty, Robert ). (In collaboration with Frances Hubbard Flaherty). My Eskimo Friends. Garden City and New York: Doubleday, Page \& Company, 1924, page I 38 (illustration).

References (unpublished): The Robert and Frances Study Center, School of Theology. "A Visual Index to the Flaherty Still Photographs: Nanook O00 I-0383."' Claremont University http://umw.cst.edu/flaherty/ VIS_INDEX_NANOOK_000I.pdf, page 2, frame NI7.

Related objects at LAC: There are two related objects on loan from The Robert and Frances Flaherty Study Center at School of Theology, Claremont University, Claremont, California to LAC. Both have the same title and $L A C$ reference numbers. LAC reference numbers: Item number 017 ; other accession number 1985-105 NPC; copy negative PA-1 43327.

1. The Barren Lands, Northern Ungava] (Figure 21) Gelatin silver nitrate negative Image: $15 \times 11.6 \mathrm{~cm}$; Sheet: $15.8 \times 12.4 \mathrm{~cm}$. Note: Negative edges have black tape around it.

2. [The Barren Lands, Northern Ungava]

Photogravure

Image: $21.5 \times 16.7 \mathrm{~cm}$; Sheet: $55.8 \times 33.6 \mathrm{~cm}$. Inscriptions: (Recto) c.r.: "ROBERT J. FLAHERTY, F.R.G.S."; I.I.:" "c (circled) REVILLON FRERES, N.Y.'; I.I.: "THE BARREN LANDS/Northern Ungava" (Imprinted)

(Fig. 2I)

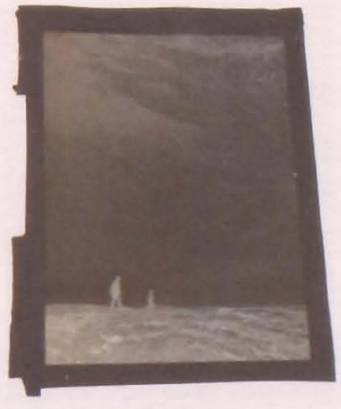

The Barren Lands, Northern Ungava Gelatin silver nitrate negative LAC on loan from The Robert and Frances Flaherty Study Center, School of Theology, Claremont University, Claremont, California.

(Credit: Robert J. Flaherty / Library and Archives of Canada / PA- 143327) 


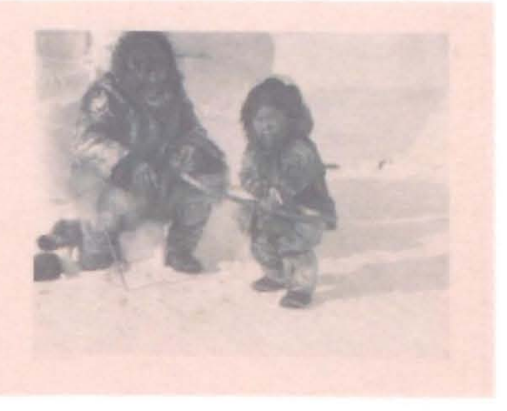

\section{CATALOGUE 27}

AGO accession number: $92 / 89.4$

Photographer: Robert J. Flaherty (1884-1951)

Title names: Youthful Hunter (Imprinted, Published title, AGO Primary title); Youthful Hunter from Nanook Studies (Descriptive, Inscribed on matte)

Date of object: 1920-1921 (Negative date);

1922 (Published date)

Medium: Photogravure

Dimensions: Image: $16.9 \times 21.5 \mathrm{~cm}(69 / 16 \times 87 / 16 \mathrm{in}$.) Sheet: $49.8 \times 32.8 \mathrm{~cm}(195 / 8 \times 1215 / 16 \mathrm{in}$. $)$

Portfolio: Camera Studies of the Far North

Constituents (object related): Publisher: G.P. Putnam's Sons, New York; Image copyright holder: Revillon Frères, New York; Photogravure printer:The American Gravure Company, N.Y.C.

Inscription: (Recto) c.r:. "ROBERT J. FLAHERTY, F.R.G.S." (Imprinted); c.l.: "c (circled) REVILLON FRERES, N.Y.' (Imprinted); I.I.: "YOUTHFUL HUNTER" (Imprinted)

Alternate number: AGOID \# 20772

Notes: Man and boy in image probably Allakariallak Nanook and Phillipoosie. See catalogue by Birnie Danzker, page 89 (catalogue 102).

\section{Related object at AGO: None}

Provenance: Gift of Susan Osborn, 1992

Exhibition history: "Robert Flaherty: Camera Studies", AGO, 15 June - 18 September 1994

References (published): Flaherty, Robert J. (In collaboration with Frances Hubbard Flaherty). My Eskimo Friends. Garden City and New York: Doubleday, Page \& Company, 1924, page 122 (illustration).
Birnie Danzker, Jo-Anne. Robert Flaherty, Photographer / Filmmaker:The Inuit 1910-1922.Vancouver, British Columbia:Vancouver Art Gallery, 1979, page 59 (illustration appears to be slightly cropped), page 89 (catalogue 102). Birnie Danzker, Jo-Anne, "Robert Flaherty/ Photographer", Studies in Visual Communication, 6, No.2, Summer 1980, 46 (illustration and catalogue 102).

References (unpublished): The Robert and Frances Study Center, School of Theology. "A Visual Index to the Flaherty Still Photographs: Nanook 000 I-0383." Claremont University http://mwn.cst.edu/flaherty/VIS_INDEX_NANOOK_000I.pdf, page 6, frame NI53.

Related objects at LAC: There are three related objects on loan from The Robert and Frances Flaherty Study Center at School of Theology, Claremont University, Claremont, California to LAC. All have the same title and $L A C$ reference numbers. $L A C$ reference numbers: Item number 0153; other accession number 1979-242 NPC; copy negative PA- 121986.

I. Man with boy (probably Allakariallak/Nanook and Phillipoosie)

Photogravure.

Image: $16.8 \times 22 \mathrm{~cm}$; sheet: $54.4 \times 32.7 \mathrm{~cm}$.

Inscriptions: (Recto) c.r.: "ROBERT J. FLAHERTY, F.R.G.S."' c.l.." "c (circled) REVILLON FRERES, N.Y."

2. Man with boy (probably Allakariallak/Nanook and Phillipoosie)

Gelatin silver print.

Image: $16.9 \times 21.9 \mathrm{~cm}$; Sheet: $20.2 \times 25.7 \mathrm{~cm}$.

Inscriptions: (Recto) I.r.: "NPI ART 5"; (Verso) u.r.: "2I-B" (inscribed in blue graphite); 1...: "1985-105" (inscribed in graphite); I.c.: "Youthful Hunter"; "Catalog no. 206" (inscribed in graphite).

3. Man with boy (probably Allakariallak/Nanook and Phillipoosie) (Figure 22 and Figure 23)

Gelatin silver photograph.

Image: $18.8 \times 24.4 \mathrm{~cm}$; Sheet: $20.2 \times 25.7 \mathrm{~cm}$.

Inscriptions: (Verso) u.l.: "NI53/ C" (inscribed in graphite); u.r.: "THE MUSEUM OF MODERN ART/ FILM LIBRARY/ I I WEST 32ND STREET NEWYORK" (Stamped): "45/ NANOOK" (inscribed in graphite); c: "2 pp |3p"/ "2101" (circled) (Inscribed in graphite; c.r.: "THE MUSEUM OF MODERN ART/ FILM LIBRARY / I I WEST 32ND STREET NEW YORK" (Stamped). 
(Fig. 22) Recto

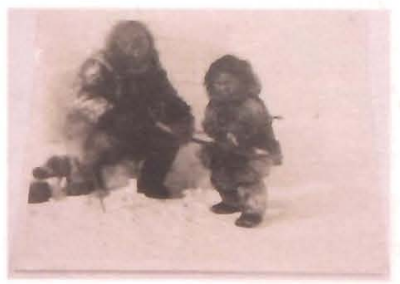

(Fig. 23) Verso

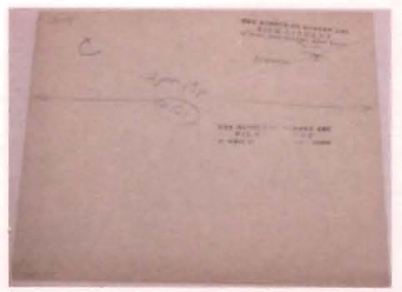

Man with boy (probably Allakariallak/Nanook and Phillipoosie)

Gelatin silver print

LAC on loan from The Robert and Frances Flaherty Study Center, School of Theology,

Claremont University, Claremont, California

(Credit: Robert J. Flaherty / Library and Archives of

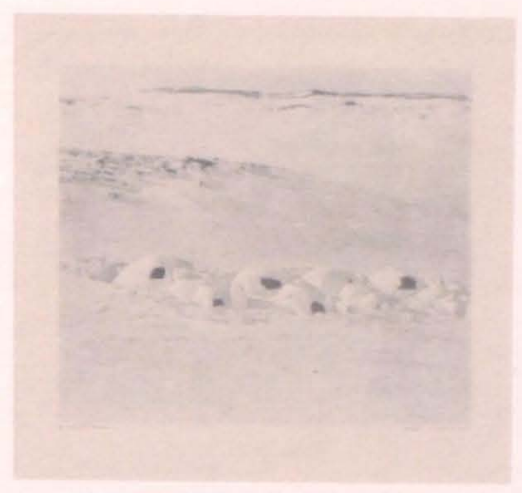

\section{CATALOGUE 28}

AGO accession number: $92 / 89.5$

Photographer: Robert J. Flaherty (|884-1951)

Title names: Abandoned Eskimo Village (Imprinted, Published title, AGO Primary title); Igloos from Nanook Studies (Inscribed on matte)

Date of object: 1910-1916 (Negative date); 1922 (Published date)

Date note: A diary entry for Saturday, 16 March 1912 (Second Expedition) states that Flaherty "came across many deserted igloos" and "took many photos, igloos and dogs..." which might to this image, and indicate that it was taken in 1912, long before the Fourth Expedition (1920-1921). Christopher, Robert J. Robert and Frances Flaherty: A Documentary Life, I883-1922. Montreal, Quebec: McGill-Queen's University Press, 2005, page 94.

Medium: Photogravure

Dimensions: Image: $16.6 \times 14.2 \mathrm{~cm}(69 / 16 \times 59 / 16$ in.) Sheet: $32.4 \times 49.8 \mathrm{~cm}(123 / 4 \times 195 / 8 \mathrm{in}$.)

Portfolio: Camera Studies of the Far North

Constituents (object related): Publisher: G.P. Putnam's Sons, New York; Image copyright holder: Revillon Frères, New York; Photogravure printer: The American Gravure Company, N.Y.C.

Inscription: (Recto) c.r:. "ROBERT J. FLAHERTY, F.R.G.S." (Imprinted); c.l.." "c (circled) REVILLON FRERES, N.Y." (Imprinted)

Alternate number: AGOID \# 20773

Notes: Label with title (Imprinted) "Abandoned Eskimo Village" has been removed.

Related object at AGO: None

Provenance: Gift of Susan Osborn, 1992

Exhibition history: None 
References (unpublished): The Robert and Frances Study Center, School of Theology. "A Visual Index to the Flaherty Still Photographs: Nanook 000 I-0383." Claremont University http://wnw.cst.edu/flaherty/NIS_INDEX_NANOOK_000I.pdf, page 6, frame NI 48.

Related objects at LAC: There are five related objects on loan from The Robert and Frances Flaherty Study Center at School of Theology, Claremont University, Claremont, California to LAC. All have the same title and $L A C$ reference numbers. $L A C$ reference numbers: Item number 0148; other accession number 1985-105 NPC; copy negative PA-143435.

I. Two igloos built side by side and maybe partial view of a third one on the right: windows are seen as dark spots Photogravure. Image: 14.1 × $16.7 \mathrm{~cm}$; Sheet: $48.3 \times 32.7$ cm. Inscriptions: (Recto) c.r.: "ROBERT J. FLAHERTY, F.R.G.S."; c.l.:."c (circled) REVILLON FRERES, N.Y.'; I.I.: "ABANDONED ESKMO VILLAGE/ Ungava Coasat of Hudson Bay" (Imprinted).

2. Two igloos built side by side and maybe partial view of a third one on the right: windows are seen as dark spots (Figure 24)

Gelatin silver print. Image: $17.4 \times 20.9$; Sheet: $17.5 \times 25.9$ cm. Inscriptions: (Verso) I.r.: "NPI ART 6" (Imprinted); (Verso) u.l.: "400 S-I"/ also in photogravure" (inscribed in graphite); u.r.: "NI 48 FF" (Inscribed in graphite); I.I. "I 985-105" (Inscribed in graphite); I.c.." Abandoned Eskimo Village" (Inscribed in graphite); I.r: "Catalog no. 400 S-I" (Inscribed in graphite).

3. Two igloos built side by side and maybe partial view of a third one on the right: windows are seen as dark spots (Figure 25)

Gelatin silver print. Image: $14.2 \times 9.3 \mathrm{~cm}$; Sheet: 17.7 $\times 11.2 \mathrm{~cm}$. Inscriptions: (Verso) u...." NI 48negative (cropped)" (inscribed in graphite); I...: "1 985-105" (inscribed in graphite). Note: Image has been cropped compared to photogravure image.

4. Two igloos built side by side and maybe partial view of a third one on the right: windows are seen as dark spots (Figure 26)

Gelatin silver print. Image: 14.1 × $9.2 \mathrm{~cm}$; Sheet: $14.1 \times$ 9.2. Inscriptions: (Verso) u.c.: "NI 48 (Cropped)"; c: "G deserted Village"; 1...: "N-400 S-I/ 1985-105"; I.c.:"PAI43435"; I.r:. "Nf"'?] (all inscribed in graphite).
5. Two igloos built side by side and maybe partial view of a third one on the right: windows are seen as dark spots (Figure 27)

Gelatin silver print. Image: $14.1 \times 9.2 \mathrm{~cm}$; Sheet: $14.1 \times$ $9.2 \mathrm{~cm}$. Inscriptions: u.r.: "5"; c: "NI 48/ (cropped)" (all inscribed in graphite).

Note: Residual glue marks and black pieces of paper on back of photograph.

(Fig. 24)

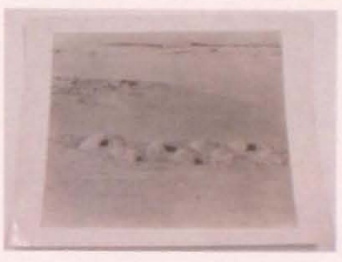

(Fig. 25)

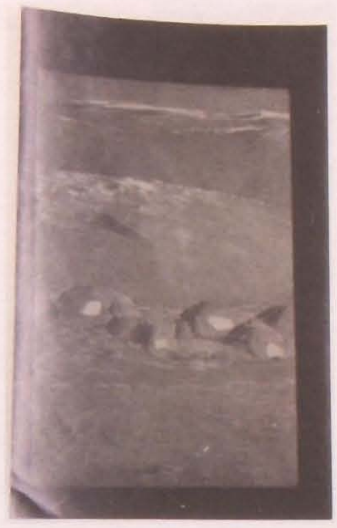

(Fig. 26)

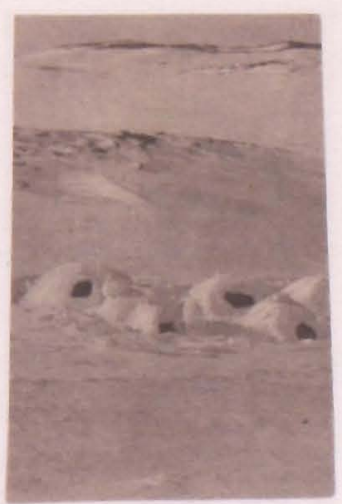


(Fig. 27)

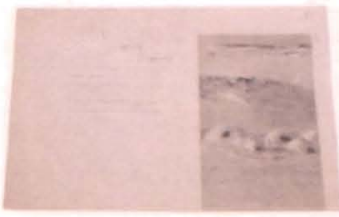

Two Igloos Built Side by Side and Maybe Partial View of a Third One on the Right: Windows are Seen as Dark Spots Gelatin silver print

LAC on loan from The Robert and Frances Flaherty Study Center, School of Theology,

Claremont University, Claremont, California.

(Credit: Robert J. Flaherty / Library and Archives of Canada / PA- 143435)

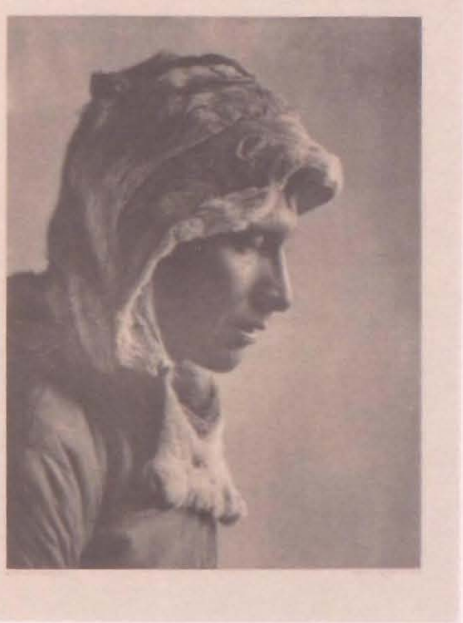

\section{CATALOGUE 29}

AGO accession number: $92 / 89.7$

Photographer: Robert J. Flaherty (1884-1951)

Title names: A Labrador Cree (Indian) Northern Labrador (Imprinted, Published title, AGO Primary title); A Labrador Cree (Indian) Northern Labrador from Portrait Studies (Inscribed on matte)

Date of object: 1910-1916 (Negative date); 1922 (Published date)

Date note: "c. 1912" previous date for object.

Medium: Photogravure

Dimensions: Image: $21.4 \times 16.5 \mathrm{~cm}(1215 / 16 \times 61 / 2$ in.) Sheet: $50 \times 32.8 \mathrm{~cm}(1911 / 16 \times 1213 / 16 \mathrm{in}$.)

Portfolio: Camera Studies of the Far North

Constituents (object related): Publisher: G.P. Putnam's Sons, New York; Image copyright holder: Revillon Frères, New York; Photogravure printer: The American Gravure Company, N.Y.C.

Inscription: (Recto) c.r.: "ROBERT J. FLAHERTY, F.R.G.S." (Imprinted); c.l.:"c (circled) REVILLON FRERES, N.Y." (Imprinted); |.I.: "A LABRADOR CREE/ (INDIAN)/ Northern Labrador" (Imprinted)

Alternate number: AGOID\# 20775; Photo Negative Number $\mathrm{N}-8580$

Related object at AGO: None

Provenance: Gift of Susan Osborn, 1992

Exhibition history: "Robert Flaherty: Camera Studies", AGO, 15 June - 18 September 1994

References: None 
Related objects at LAC: Unidentified Man Wearing a Fur Hood

Gelatin silver print.

LAC reference numbers: Item number N-2829, Other accession number 1985- 105 NPC, Copy negative PA-1 47783. on loan from The Robert and Frances Flaherty Study Center at School of Theology, Claremont University, Claremont, California.

Photograph was not found in April 2010.

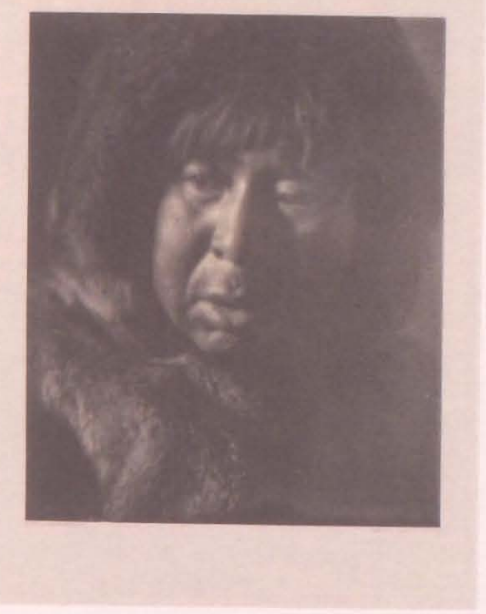

\section{CATALOGUE 30}

AGO accession number: 92/89.7

Photographer: Robert J. Flaherty (1884-1951)

Title names: Sapa, Sikoslingmint Eskimo of Southern Baffin Land (Imprinted, Published title, AGO Primary title);

Portrait of Man (Nascaupie), Fort Chino from Portrait Studies (Inscribed on matte)

Date of object: 1910-1916 (Negative date); 1922 (Published date)

Date note: "1922 c." previous date for object.

Medium: Photogravure

Dimensions: Image: $19.6 \times 16.4 \mathrm{~cm}(7 / 1 / 16 \times 67 / 16$ in.) Sheet: $50.5 \times 32 \mathrm{~cm}(197 / 8 \times 125 / 8 \mathrm{in}$.)

Portfolio: Camera Studies of the Far North

Constituents (object related): Publisher: G.P. Putnam's Sons, New York; Image copyright holder: Revillon Frères, New York; Photogravure printer: The American Gravure Company, N.Y.C.

Inscription: (Recto) c.r.: ROBERT J. FLAHERTY, F.R.G.S. (Imprinted); c.l.: c (circled) REVILLON FRERES, N.Y. (Imprinted)

Alternate number: AGOID\# 2077

Notes: Label with title (Imprinted) "Sapa, Sikoslingmuit Eskimo of Southern Baffin land" has been removed.

Related object at AGO: None

Provenance: Gift of Susan Osborn, 1992

Exhibition history: None 
References: (unpublished): The Robert and Frances Study Center, School of Theology. "A Visual Index to the Flaherty Still Photographs: Nanook 2001 -24I 6." Claremont University http://www.cst.edu/flaherty/VIS INDEX_NANOOK_200 I.pdf, page 4, frame N2079.

Related objects at LAC: There are four related objects: three on loan from The Robert and Frances Flaherty Study Center at School of Theology, Claremont University, Claremont, California to LAC. All have the same LAC reference numbers: Item number 2079; Other accession number 1979-242 NPC; copy negative PA-500772.

I. [Man identified as Sapa] (Figure 28)

Gelatin silver glass negative.

Image: $17.6 \times 12.6 \mathrm{~cm}$; Sheet (glass): $17.6 \times 12.6$ cm. Inscriptions: (Verso) u.l.:" 390" (Inscribed in ink) on piece of white paper adhered to glass; I.r: "FN-292B" (Inscribed in ink.)

2. [Man identified as Sapa] (Figure 29)

Gelatin silver print (matted). Image: $19.8 \times 17 \mathrm{~cm}$; Sheet: $19.8 \times 17 \mathrm{~cm}$. First matte: $22 \times 18.8 \mathrm{~cm}$; Second matte: $22.4 \times 19.4 \mathrm{~cm}$.

Inscriptions: (Recto) I.1.:. "C"; I.r.: "FN:292-B" (all inscribed in ink); (Verso) C: "FN. 292 B (circled)/ 5 $\times 7 \mathrm{P}^{\prime \prime}$ (Inscribed in graphite).

3. [Man identified as Sapa] (Figure 30)

Photogravure [?] on tissue paper. Image: $19.8 \times$ $16.2 \mathrm{~cm}$; Sheet: $22.6 \times 18 \mathrm{~cm}$.

\section{Robert Flaherty Collection}

(I of 6 prints from Camera Studies of the Far North portfolio)

Photogravure

Image: $19.2 \times 16.4 \mathrm{~cm}$; Sheet: $50.5 \times 33 \mathrm{~cm}$.

Inscriptions: (Recto) c.r.: ROBERT J. FLAHERTY, F.R.G.S. (Imprinted); c.l:: c (circled) REVILLON FRERES, N.Y. (Imprinted); I.I.: "SAPA Sikoslingmuit Eskimo of Southern Baffin Land" (Imprinted); (Verso) I.I.: "C-143635/ 1989-477 - |". LAC reference number: Box A268-01, Item number assigned by LAC I, Other accession number 1989-477 DAP, Copy negative C-143635.
(Fig. 28) Verso

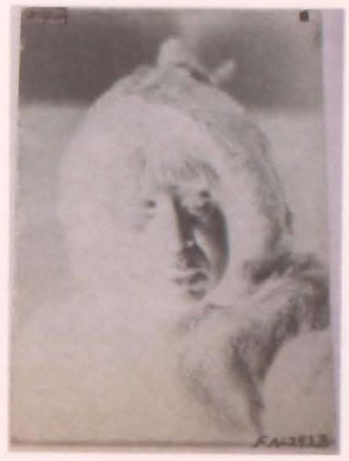

(Fig. 29)

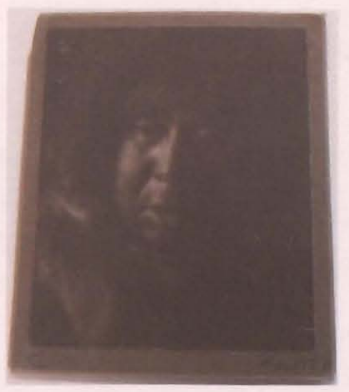

(Fig. 30)

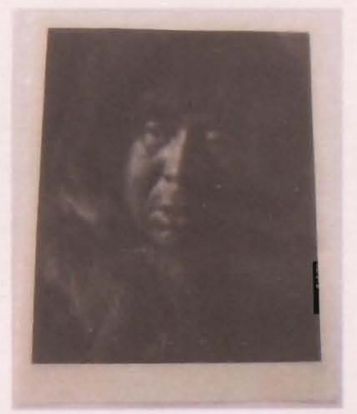

Man identified as Sapa

(Fig. 28) Gelatin silver glass plate negative

(Fig. 39) Gelatin silver print (matted)

(Fig. 30) Photogravure [?] on tissue

LAC on loan from The Robert and Frances Flaherty Study Center, School of Theology,

Claremont University, Claremont, California.

(Credit: Robert J. Flaherty / Library and Archives of Canada / PA-500772) 


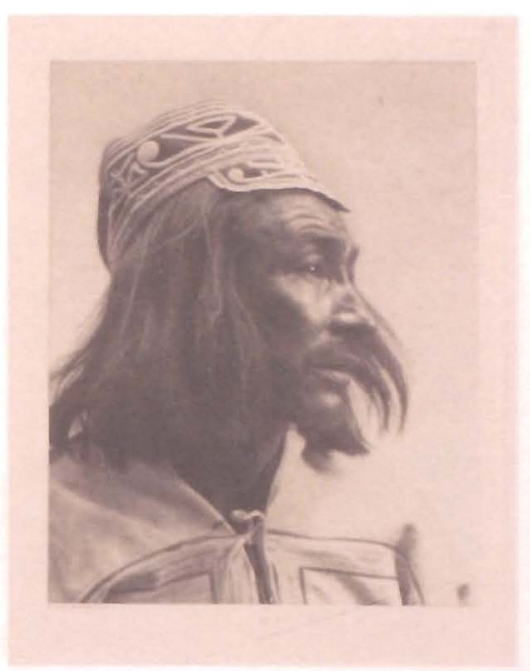

\section{CATALOGUE 3।}

AGO accession number: $92 / 89.10$

Photographer: Robert J. Flaherty (1884-1951)

Title names: Nascaupie, Indian Chief, Northern Labrador (Imprinted, Published title, AGO Primary Title)

Date of object: 1912 (Negative date); 1922 (Published date)

Date note: Negative date from catalogue by Birnie Danzker, page 86 (catalogue 31).

Medium: Photogravure

Dimensions: Image: $21.5 \times 17 \mathrm{~cm}(87 / 16 \times 611 / 16$ in. $)$ Sheet: $47.5 \times 32.4 \mathrm{~cm}(1811 / 16 \times 123 / 4$ in. $)$

Portfolio: Camera Studies of the Far North

Constituents (object related): Publisher: G.P. Putnam's Sons, New York; Image copyright holder: Revillon Frères, New York; Photogravure printer:The American Gravure Company, N.Y.C.

Inscription: (Recto) c.r: ROBERT J. FLAHERTY, F.R.G.S.; c.l.: c (circled) REVILLON FRERES, N.Y. (Imprinted)

Alternate number: AGOID \# 20778

Notes: Label with title (Imprinted) "Nascaupie, Indian Chief, Northern Labrador" has been removed.

Related object at AGO: Catalogue $7(93 / 280.4)$ is a gelatin silver bromide print from the same negative.

Provenance: Gift of Susan Osborn, 1992

Exhibition history: "Robert Flaherty: Camera Studies", AGO, 15 June - 18 September 1994
References (published): Flaherty, Robert J. (In collaboration with Frances Hubbard Flaherty). My Eskimo Friends. Garden City and New York: Doubleday, Page \& Company, 1924, page 82 (illustration).

Birnie Danzker, Jo-Anne. Robert Flaherty, Photographer / Filmmaker:The Inuit I 10-1922.Vancouver, British Columbia:Vancouver Art Gallery, 1979, pages 38, 86 (catalogue 31).

Birnie Danzker, Jo-Anne, "Robert Flaherty/ Photographer", Studies in Visual Communication, 6, No.2, Summer 1980, 18 (illustration and catalogue 31).

References (unpublished): The Robert and Frances Study Center, School of Theology. "A Visual Index to the Flaherty Still Photographs: Nanook 000 I-0383." Claremont University http://mww.cst.edu/flaherty/ VIS_INDEX_NANOOK_000I.pdf, page 6, frame NI52.

Related object at LAC: Indian Chief Nascaupie, Northern Labrador

Photogravure

Image: $21.5 \times 17.2 ;$ Sheet: $50.5 \times 33.5$

Inscriptions: 1.1.: "NASCAUPIE INDIAN CHIEF/ Northern Labrador" (imprinted)

On loan from The Robert and Frances Flaherty Study Center at School of Theology, Claremont University,

Claremont, California to LAC.

LAC reference numbers: Item number 0 152; Other Accession Number 1979-242 NPC; Copy negative PA-121983. 


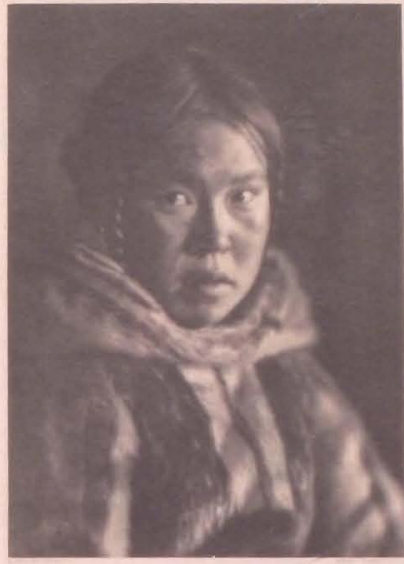

\section{CATALOGUE 32}

AGO accession number:92/89.11

Photographer: Robert J. Flaherty (|884-195|)

Title names: Canayou (The Sculpin). Sikoslingmint Eskimo Girl, Southern Baffin Land (Imprinted, Published title, AGO Primary Title)

Date of object: 1913-1914 (Negative date); 1922 (Published date)

Date note: Negative date from catalogue by Birnie Danzker, page 86 (catalogue 32).

Medium: Photogravure

Dimensions: Image: $21.4 \times 15.3 \mathrm{~cm}(87 / 16 \times 6$ in.); Sheet: $37.5 \times 32 \mathrm{~cm}(143 / 4 \times 125 / 8$ in. $)$

Portfolio: Camera Studies of the Far North

Constituents (object related): Publisher: G.P.Putnam's Sons, New York; Image copyright holder: Revillon Frères, New York; Photogravure printer:The American Gravure Company, N.Y.C.

Inscription: (Recto) c.r.:"ROBERT J. FLAHERTY,

F.R.G.S." (Imprinted); c.l.:"c (circled) REVILLON FRERES, N.Y." (Imprinted)

\section{Alternate number: AGOID \# 20779}

Notes: Label with title (Imprinted) "Canayou (The Sculpin), Sikoslingmuit Eskimo Girl, Southern Baffin Land" has been removed.

Identified as Narlaq. See catalogue by Birnie Danzker, page 86 (catalogue 32)

Related object at AGO: None

Provenance: Gift of Susan Osborn, 1992

Exhibition history: "Robert Flaherty: Camera Studies", AGO, 15 June - 18 September 1994
References (published): Birnie Danzker, Jo-Anne.

Robert Flaherty, Photographer / Filmmaker: The Inuit I 10-1922. Vancouver, British Columbia:Vancouver Art Gallery, 1979, pages 30, 86 (catalogue 32).

Birnie Danzker, Jo-Anne, "Robert Flaherty/ Photographer", Studies in Visual Communication, 6, No.2, Summer 1980, 17 (illustration and catalogue 32).

References (unpublished): The Robert and Frances Study Center, School of Theology. "A Visual Index to the Flaherty Still Photographs: Nanook 000 I-0383." Claremont University http://www.cstedu/flahertyNIS_ INDEX_NANOOK_000I.pdf, page 7, frame N2I0.

Related object at LAC: There are two related objects on loan from The Robert and Frances Flaherty Study Center at School of Theology, Claremont University, Claremont, California to LAC. All have the same title and $L A C$ reference numbers. $L A C$ reference numbers: Item number 0210; other accession number 1979-242 NPC; copy negative PA-500256.

I. [Woman identified as Narlaq] (Figure 31)

Gelatin silver nitrate negative.

Image: $16.7 \times 12.6 \mathrm{~cm}$; Sheet (glass): $17.6 \times 12.8 \mathrm{~cm}$. Inscription: (Verso) 1.1.:" "FN-247 " (inscribed in ink). Note: Negative image is out of focus.

\section{2. . [Woman identified as Narlaq]}

Photogravure.

Image: $21.9 \times 15.9 \mathrm{~cm}$; Sheet: $50.8 \times 32.8 \mathrm{~cm}$. Inscriptions: "CUNAYOU/ (THE SCULPIN)/Sikoslingmuit Eskimo Girl/ Southern Baffin Land" (Imprinted).

(Fig. 3I) Recto

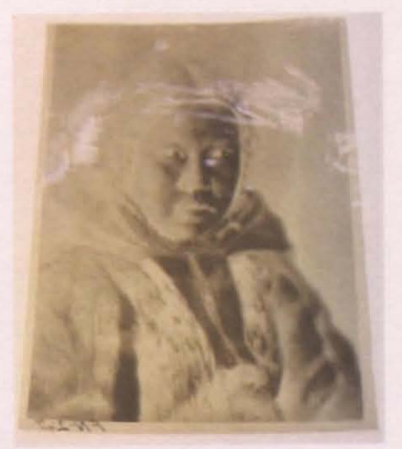

Woman identified as Narlaq

Gelatin silver nitrate negative

LAC on loan from The Robert and Frances Flaherty

Study Center, School of Theology,

Claremont University, Claremont, California

Credit: Robert J. Flaherty / Library and Archives of Canada / PA-500256) 


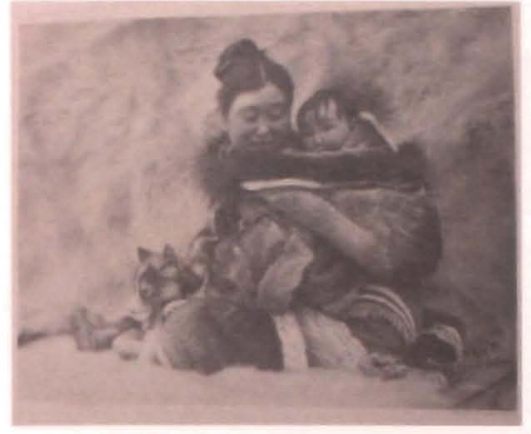

\section{CATALOGUE 33}

AGO accession number: $2007 / 159.4$

Photographer: Robert J. Flaherty (1884-1951)

Title names: Nyla and Child: Eteeveemuit Eskimo of Cape Dufferin, Northwestern Ungava (Imprinted, Published title); Nyla and Child - Eteeveemuit Eskimo of Cape Dufferin, Northwestern Ungava, from Camera Studies of the Far North (Descriptive, AGO Primary title, Inscribed on matte)

Date of object: 1920-1921 (Negative date); 1922 (Published date)

Date note: "1925 c" previous date for object.

Medium: Photogravure

Dimensions: Image: $16.7 \times 21.1 \mathrm{~cm}(69 / 16 \times 85 / 16$ in. $)$ Sheet: $49 \times 32.9 \mathrm{~cm}(195 / 16 \times 1215 / 16 \mathrm{in}$.)

Portfolio: Camera Studies of the Far North

Constituents (object related): Publisher: G.P. Putnam's Sons, New York; Image copyright holder: Revillon Frères, New York; Photogravure printer:The American Gravure Company, N.Y.C.

Inscription: (Recto) c.r.: "ROBERT J. FLAHERTY, F.R.G.S." (Imprinted); c.l.:"c (circled) REVILLON FRERES,

N.Y.' (Imprinted); I.I.:."NYLA AND CHILD/ Eteeveemuit Eskimo of Cape Dufferin/ Northwestern Ungava" (Imprinted)

Alternate number: AGOID \# 103422

Related object at AGO: None

Provenance: Anonymous donation, 2007

Exhibition history: None
References (published): Flaherty, Robert J. (In collaboration with Frances Hubbard Flaherty). My Eskimo Friends. Garden City and New York: Doubleday, Page \& Company, 1924, page 106 (illustration)

References (unpublished): The Robert and Frances Study Center, School of Theology. "A Visual Index to the Flaherty Still Photographs: Nanook 000 I-0383." Claremont University http://www.cst.edu/flahertyNIS_ INDEX_NANOOK_0001.pdf, page 7, frame NI95.

Related object at LAC: Robert Flaherty Collection (I of 5 prints from Camera Studies of the Far North portfolio)Photogravure.

Image $16.3 \times 21.1 \mathrm{~cm}$; Sheet: $55.7 \times 33 \mathrm{~cm}$.

Inscriptions: (Recto) c.r:" "ROBERT J. FLAHERTY, F.R.G.S." (Imprinted); c.l.." "c (circled) REVILLON FRERES, N.Y.'(Imprinted); I.I.: "NYLA AND CHILD/ Eteeveemuit Eskimo of Cape Dufferin/ Northwestern Ungava" (Imprinted).

LAC reference numbers: Box A268-01, Item number assigned by LAC \#, Other accession number 1991-367 DAP, copy negative C-143634; C-1 43636. 


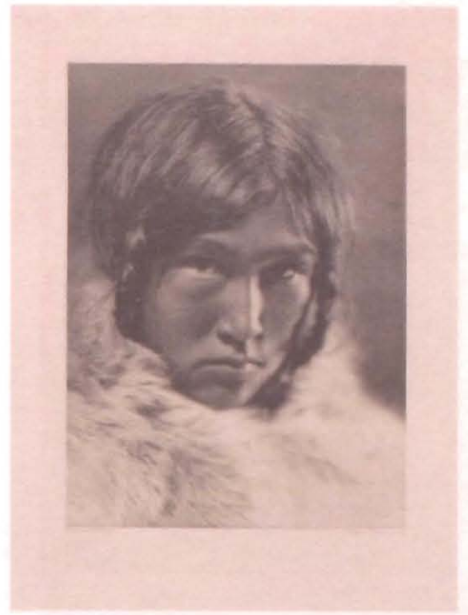

\section{CATALOGUE 35}

\section{AGO accession number: $2007 / 159.5$}

Photographer: Robert J. Flaherty (|884-1951)

Title names: Allegoo (Shining Water), Sikoslingmuit Eskimo Woman, Southern Baffin Land (Imprinted, Published title); Allegoo (Shining Water), Sikoslingmuit Eskimo Woman, Southern Baffin island, from Camera Studies of the Far North (Descriptive, AGO Primary title, Inscribed on matte)

Date of object: 1913-1914 (Negative date);

1922 (Published date)

Medium: Photogravure

Dimensions: Image: $22.2 \times 16.3 \mathrm{~cm}(83 / 4 \times 67 / 16 \mathrm{in}$. $)$ Sheet: $50 \times 32.3 \mathrm{~cm}(1911 / 16 \times 1211 / 16 \mathrm{in}$. $)$

Portfolio: Camera Studies of the Far North

Constituents (object related): Publisher: G.P.Putnam's Sons, New York; Image copyright holder: Revillon Frères, New York; Photogravure printer:The American Gravure Company, N.Y.C.

Inscription: (Recto) c.r.: "ROBERT J. FLAHERTY, F.R.G.S." (Imprinted); c.l.: "c (circled) REVILLON FRERES, N.Y." (Imprinted); I. .:."ALLEGOO/ (SHINING WATER)/ Sikoslingmuit Eskimo Woman/ Southern Baffin Land" (Imprinted)

Alternate number: AGOID \# 103423

Notes: Young Inuit woman identified as Kanjuq (Kanajuk) in catalogue by Birnie Danzker, page 85 (catalogue 29).

Related object at AGO: None

Provenance: Anonymous donation, 2007

\section{Exhibition history: None}

References (published): Flaherty, Robert J. (In collaboration with Frances Hubbard Flaherty.). My Eskimo Friends. Garden City and New York: Doubleday, Page \& Company, 1924, page 74 (illustration).
Birnie Danzker, Jo-Anne. Robert Flaherty, Photographer I Filmmaker: The Inuit I 10-1922. Vancouver, British Columbia:Vancouver Art Gallery, 1979, page 28 (illustration), page 85 (catalogue 29).

Birnie Danzker, Jo-Anne, "Robert Flaherty/ Photographer", Studies in Visual Communication, 6, No.2, Summer 1980, 5 (illustration).

References (unpublished): The Robert and Frances Study Center, School of Theology. "A Visual Index to the Flaherty Still Photographs: Nanook 000 I-0383." Claremont University http://www.cst.edu/flahertyNIS_INDEX_NANOOK_OOOI.pdf, page 6, frame NI 50.

Related objects at LAC: There are three related objects on loan from The Robert and Frances Flaherty Study Center at School of Theology, Claremont University, Claremont, California to LAC. LAC reference numbers: Item number 0150; Other accession number 1985-105 NPC; Copy negative PA-143434, PA- 121988 and PA143434.

I. Identified as Allegoo (Shining Water) Sikoslingmuit Eskimo Woman, South Baffin Island Eskimo. Other Sources Identify her as Kanajuq or Kanajuk from the Same Area (Figure 32)

Gelatin silver print. Image: $12.9 \times 9.4 \mathrm{~cm}$; Sheet: $12.9 \times$ $9.4 \mathrm{~cm}$.

Inscriptions: (Recto) c: "N I50" (Inscribed in graphite); c.l.: "C" (Inscribed in blue); 1...:"1985-105" (Inscribed in graphite); I.r.: "PA 143434" (Inscribed in graphite).

Note: Residual black paper glued to back of photograph.

2. Identified as Allegoo (Shining Water) Sikoslingmuit Eskimo Woman, South Baffin Island Eskimo. Other Sources Identify her as Kanajuq or Kanajuk from the Same Area Photogravure. Image: $22.3 \mathrm{~cm} \times 16.4 \mathrm{~cm}$; Sheet: $55 \times$ $33.7 \mathrm{~cm}$.

Inscriptions: (Recto) c.r.: "ROBERT J. FLAHERTY, F.R.G.S." (Imprinted); c.l.: "c (circled) REVILLON FRERES, N.Y.' (Imprinted); I.I.: "ALLEGOO/ (SHININGWATER)/ Sikoslingmuit Eskimo Woman/ Southern Baffin Land" (Imprinted).

3. Identified as Allegoo (Shining Water) Sikoslingmuit Eskimo Woman, South Baffin Island Eskimo. Other Sources Identify her as Kanajuq or Kanajuk from the Same Area Photogravure. Image: $22.3 \mathrm{~cm} \times 16.4 \mathrm{~cm}$; Sheet: $55 \times$ $33.7 \mathrm{~cm}$. 
Inscriptions: (Recto) c.r.: "ROBERT J. FLAHERTY, F.R.G.S." (Imprinted); c.l.:" "c (circled) REVILLON FRERES, N.Y." (Imprinted); I.I.." ALLEGOO/ (SHINING WATER)/ Sikoslingmuit Eskimo Woman/ Southern Baffin Land" (Imprinted).

(Fig. 32)

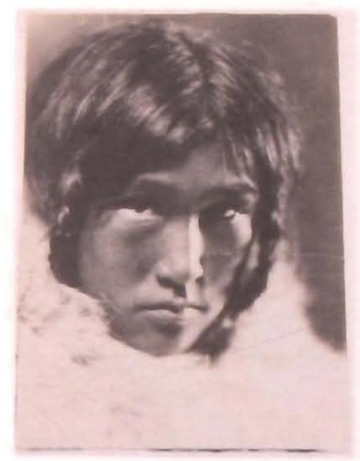

Identified as Allegoo (Shining Water) Sikoslingmuit Eskimo Woman, South Baffin Island Eskimo. Other Sources Identify her as Kanajuq or Kanajuq from the Same Area

Gelatin silver print

LAC on loan from The Robert and Frances Flaherty Study Center, School of Theology,

Claremont University, Claremont, California.

(Credit: Robert J. Flaherty / Library and Archives of Canada /PA-143434)

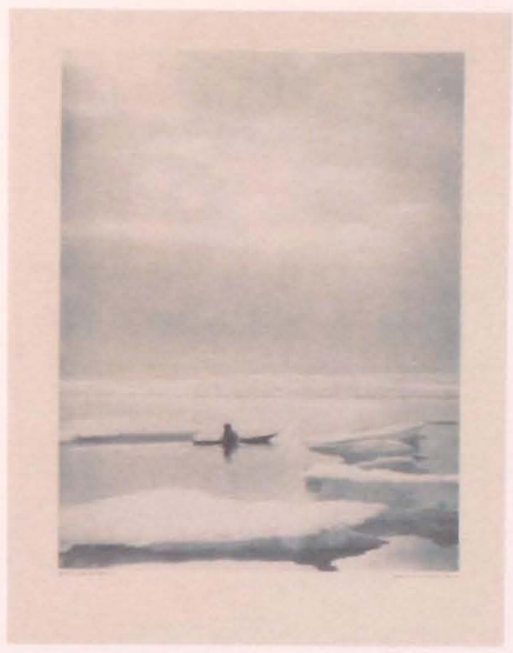

\section{CATALOGUE 35}

AGO accession number: $87 / 322$

Photographer: Robert J. Flaherty (1884-1951)

Title names: Summer (August) Eskimo Kayak in Northeastern Hudson Bay (Imprinted, Published title, AGO Primary title); Summer (August) Eskimo Kayak in Northeastern Hudson Bay (from "Nanook of the North") published by Revillon Freres (Inscribed on matte)

Date of object: 1910-1916 (Negative date); 1922 (published date)

Medium: Photogravure

Dimensions: Image: $21 \times 16.6 \mathrm{~cm}(81 / 4 \times 64 / 16$ in. $)$ Sheet: $50.5 \times 33.5 \mathrm{~cm}(197 / 8 \times 133 / 16$ in. $)$

Portfolio: Camera Studies of the Far North

Constituents (object related): Publisher: G.P. Putnam's Sons, New York; Image copyright holder: Revillon Frères, New York; Photogravure printer:The American Gravure Company, N.Y.C.

Inscription: (Recto) c.r.:"ROBERT J. FLAHERTY, F.R.G.S." (Imprinted); c.l.:"c (circled) REVILLON FRERES, N.Y." (Imprinted); I.I.:"Summer/(August)/Eskimo Kayak in Northeastern Hudson Bay" (Imprinted).

Alternate number: AGOID\# 15272

Related object at AGO: Catalogue 36 (AGO Acc. No. 92/89.6) is another copy of this photogravure.

Provenance: Gift of Sandra Ball and Marcia Reid, 1987

Exhibition history: None 
References (published): Martin, David G. and Allan D. Moore. Psychology, Principles and Applications. Scarborough, Ontario: Prentice-Hall Canada, 1991. [As per Image Reproduction Form in Registration File for this photogravure].

Related object at LAC: Related object at LAC I. Robert Flaherty Collection material ( I of 5 prints from Camera Studies of the Far North portfolio) Photogravure. Image: $21 \times 16.7 \mathrm{~cm}$; Sheet: $50.3 \times 34$ $\mathrm{cm}$.

Inscriptions: (Recto) c.r.: "ROBERT J. FLAHERTY, F.R.G.S." (Imprinted); c.l.." "c (circled) REVILLON FRERES, N.Y." (Imprinted); I.I.:"Summer/ (August)/ Eskimo Kayak in Northeastern Hudson Bay" (Imprinted)

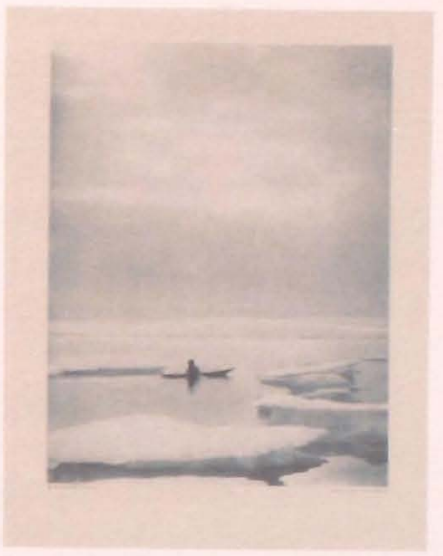

\section{CATALOGUE 36}

AGO accession number: 92/89.6

Photographer: Robert J. Flaherty (|884-1951)

Title names: Summer (August), Eskimo Kayak in North Eastern Hudson Bay (Imprinted, Published title, AGO Primary title)

Date of object: 1910-1916 (Negative date); 1922 (Published date)

Medium: Photogravure

Dimensions: Image: $211 \times 6.5 \mathrm{~cm}(81 / 4 \times 6$ 1/2 in. $)$ Sheet: $50.5 \times 32.8 \mathrm{~cm}(197 / 8 \times 1215 / 16 \mathrm{in}$. $)$

Portfolio: Camera Studies of the Far North

Constituents (object related): Publisher: G.P. Putnam's Sons, New York; Image copyright holder: Revillon Frères, New York; Photogravure printer:The American Gravure Company, N.Y.C.

Inscription: (Recto) c.r.: "ROBERT J. FLAHERTY, F.R.G.S." (Imprinted); c.l.: "c (circled) REVILLON FRERES, N.Y.' (Imprinted); l...:" Summerl (August)/ Eskimo Kayak in Northeastern Hudson Bay" (Imprinted)

Alternate number: AGOID\# 20774; Photo Negative Number N-8574

Notes: Label with title (Imprinted) "Sapa, Sikoslingmuit Eskimo of Southern Baffin land" has been removed.

Related object at AGO: Catalogue 35 (AGO Acc. No. $87 / 322$ ) is another copy of the same photogravure

Provenance: Gift of Susan Osborn, 1992

\section{Exhibition history: None}

Related object at LAC: Robert Flaherty Collection (I of 5 prints in Camera Studies of the Far North portfolio) Photogravure. Image: 21 × $16.7 \mathrm{~cm}$; Sheet: $50.3 \times 34 \mathrm{~cm}$. Inscriptions: (Recto) c.r.: "ROBERT J. FLAHERTY, F.R.G.S." (Imprinted); c.l.." "c (circled) REVILLON FRERES, N.Y." (Imprinted); I...:" "Summerl (August)/ Eskimo Kayak in Northeastern Hudson Bay" (Imprinted). 


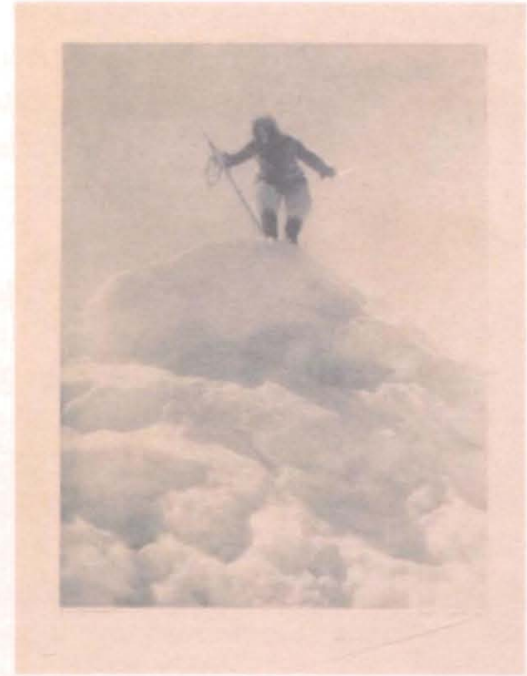

CATALOGUE 37

AGO accession number: $87 / 323$

Photographer: Robert J. Flaherty (| 884-195|)

Title names: The Hunter, Eskimo in the Rough Ice fields at Sea (Imprinted, published title); The Hunter: Eskimo in the rough ice-fields at sea (from "Nanook of the North") published by Revillon Freres (Descriptive, AGO Primary title); The Hunter.Eskimo in the Rough Ice Fields at sea, 1920-1921 From "Camera Studies of the Far North", (Revillon Freres; published by G.P Putnam, N.Y., 1922) (Inscribed on matte)

Date of object: 1921 - 1922 (Negative date); 1922 (Published date)

Date note: "I925 c" previous date for object

Medium: Photogravure

Dimensions: Image: $21.7 \times 16.5 \times \mathrm{cm}(89 / 16 \times 6 / / 2 \times$ in.) Sheet: $50 \times 33 \mathrm{~cm}(1911 / 16 \times 13 \times$ in. $)$

Portfolio: Camera Studies of the Far North

Constituents (object related): Publisher: G.P. Putnam's Sons, New York; Image copyright holder: Revillon Frères, New York; Photogravure printer:The American Gravure Company, N.Y.C.

Inscription: (Recto) c.r.: "ROBERT J. FLAHERTY, F.R.G.S." (Imprinted); c.l.: "c (circled) REVILLON FRERES, N.Y.' (Imprinted); I.I..."THE HUNTER/ Eskimo in the rough ice fields at sea" (Imprinted)

\section{Alternate number: AGOID \# |527|}

Notes: Label with title (Imprinted) "Abandoned Eskimo Village" has been removed.

Related object at AGO: Catalogue 38 (AGO Acc. no. 2007/159.3) is another copy of the same photogravure.
Provenance: Gift of Sandra Ball and Marcia Reid, 1987

Exhibition history: None

References (published): Flaherty, Robert J. (In collaboration with Frances Hubbard Flaherty.).My Eskimo Friends. Garden City and New York: Doubleday, Page \& Company, 1924, page 18 (illustration).

References (unpublished): The Robert and Frances Study Center, School of Theology. "A Visual Index to the Flaherty Still Photographs: Nanook 000 I -0383." Claremont University http://mww.cst.edu/flahertyNIS_INDEX_NANOOK_O00I.pdf, page 9, frame N263.

Related objects at LAC: There are five related objects on loan from The Robert and Frances Flaherty Study Center at School of Theology, Claremont University, Claremont, California to LAC. All have the same title and LAC reference numbers: Item number 0263; Other accession number 1985-105 NPC; copy negative PA143089.

\section{Still Photo from the Film NANOOK OFTHE} NORTH Showing the Hunter Probably Nanook/AIlakariallak in the Rough Ice Fields at Sea (Figure 33 and Figure 34)

Gelatin silver print with tissue overlay. Image: $23.3 \times 17.5 \mathrm{~cm}$. Sheet: $25.8 \times 20.1 \mathrm{~cm}$.

Inscriptions on tissue overlay: (Recto) u.r: "enlarged to 10'" (Inscribed in graphite); cr.:. "I 45 1/2" (circled) (Inscribed in graphite). Inscriptions on photograph: (Recto) I.I.:" MOVING PICTURE STILLS (Imprinted) Nanook of the North (Inscribed in ink)"; (Verso) u.l.:" N-500 S-3/ N263" (Inscribed in graphite); u.r.: "Nanook of the North"/ Special file" (Inscribed in graphite); c: "THE MUSEUM OF MODERN ART/ FILM LIBRARY/ 53RD STREET NEWYORK" (stamped); I.1.." "1 985- I05"; I.r.: "PAI 43089; "gN" (Inscribed in graphite).

2. Still Photo from the Film NANOOK OFTHE NORTH Showing the Hunter Probably Nanook/Allakariallak in the Rough Ice Fields at Sea Gelatin silver print: Image: $17.5 \times 23.3 \mathrm{~cm}$; Sheet: $20.1 \times 25.8 \mathrm{~cm}$. Inscriptions: I.c.: "NPI 4".

\section{Still Photo from the Film NANOOK OFTHE} NORTH Showing the Hunter Probably Nanook/Allakariallak in the Rough Ice Fields at Sea

Gelatin silver print. Image: $21.6 \times 16.7 \mathrm{~cm}$; Sheet: $51.6 \times 33.5 \mathrm{~cm}$. Inscriptions: (Recto) I.r.: "no neg found" (Inscribed). 
4. Still Photo from the Film NANOOK OFTHE NORTH Showing the Hunter Probably Nanook/AIlakariallak in the Rough Ice Fields at Sea (Figure 35 and Figure 36)

Gelatin silver print.

Image: $11.5 \times 6.5 \mathrm{~cm}$; Sheet: $12.1 \times 6.7 \mathrm{~cm}$.

Inscriptions: (Recto) I.1.." "F" (Inscribed in blue graphite); I.r.: "857" (Inscribed in ink). (Verso) u.r.: "N2393" (Inscribed in graphite); c.l::"210I" (circled) (Inscribed in graphite; c:" 2 p[?] / 12 p" (Inscribed in graphite); "THE MUSEUM OF MODERN ART/ FILM LIBRARY/ 53RD STREET NEW YORK" (stamped); "2 3/4" (Inscribed in graphite): "4" inscribed in graphite; I...."H24246-104 (upside down)/ 1985-105" (Inscribed in graphite; I.r.:" no neg found" (Inscribed in blue graphite)/ "80" (Inscribed in graphite)/ "PA-143656" (Inscribed in graphite).

5. Still Photo from the Film NANOOK OFTHE NORTH Showing the Hunter Probably Nanook/Allakariallak in the Rough Ice Fields at Sea

Photogravure.

Image; $21.6 \times 16.7 \mathrm{~cm}$; Sheet: $51.6 \times 33.5 \mathrm{~cm}$.

Inscriptions: (Recto) c.r.: "ROBERT J. FLAHERTY, F.R.G.S." (Imprinted); c.l.: "c (circled) REVILLON FRERES, N.Y." (Imprinted); I.I.: "THE HUNTER/ Eskimo in the rough ice fields at sea"(Imprinted).

(Fig. 33)

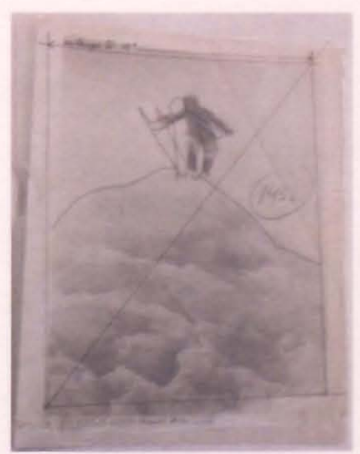

(Fig. 34) Detail

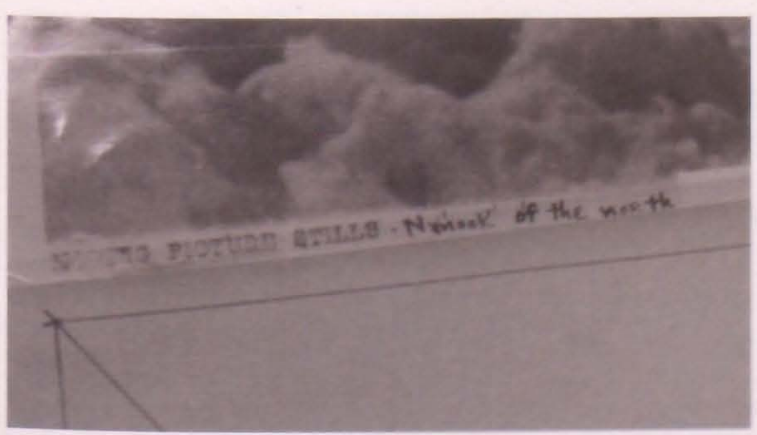

(Fig. 35) Recto

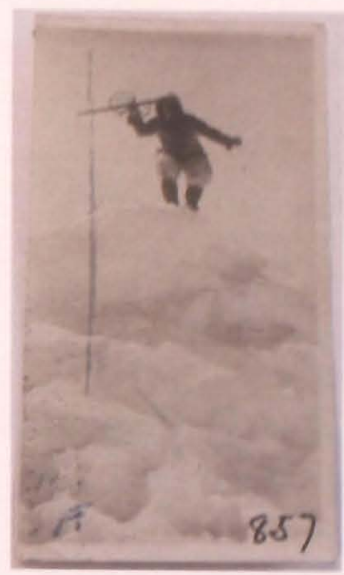

(Fig. 36) Verso

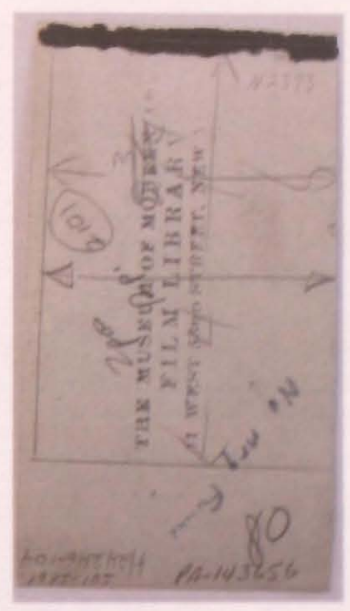

Still Photo from the Film NANOOK OFTHE NORTH Showing the Hunter Probably Nanook/Allakariallak in the Rough Ice Fields at Sea

Gelatin silver prints

LAC on loan from The Robert and Frances Flaherty Study Center, School of Theology.

Claremont University, Claremont, California.

(Credit: Robert J. Flaherty / Library and Archives of Canada / PA-143089) 


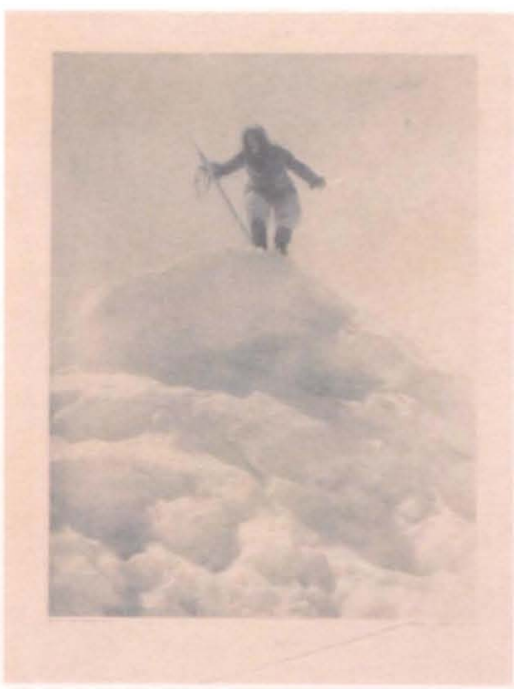

References (published): Flaherty, Robert J. (In collaboration with Frances Hubbard Flaherty.).My Eskimo Friends. Garden City and New York: Doubleday, Page \& Company, 1924, page 18.

References (unpublished): The Robert and Frances Study Center, School of Theology. "A Visual Index to the Flaherty Still Photographs: Nanook 000 I-0383." Claremont University http://www.cst.edu/flahertyNIS INDEX_NANOOK_O00I.pdf, page 9, frame N263.

Related object at LAC: See catalogue 37 (87/323) under "Related object(s) at LAC".

\section{CATALOGUE 38}

AGO accession number: 2007/159.3

Photographer: Robert J. Flaherty (|884- |95 |)

Title names: The Hunter, Eskimo in the rough ice-fields at sea (Imprinted, Published title); The Hunter - Eskimo in the rough ice fields, from Nanook of the North (Imprinted, AGO Primary title, Inscribed on matte)

Date of object: 1920-1921 (Negative date); 1922 (Published date)

Medium: Photogravure

Dimensions: Image: $21.7 \times 16.6 \mathrm{~cm}(8.5 \times 6.5$ in. $)$

Sheet: $49.5 \times 32.5 \mathrm{~cm}(19.5 \times 12.8$ in. $)$

Portfolio: Camera Studies of the Far North

Constituents (object related): Publisher: G.P. Putnam's Sons, New York; Image copyright holder: Revillon Frères, New York; Photogravure printer: The American Gravure Company, N.Y.C.

Inscription: (Recto) c.r.: "ROBERT J. FLAHERTY, F.R.G.S." (Imprinted); c.l.: "c (circled) REVILLON FRERES, N.Y." (Imprinted); l...."THE HUNTER Eskimo in the rough ice fields at sea"(Imprinted)

Alternate number: AGOID \# 103421

Related object at AGO: Catalogue 37 (AGO Acc. no. $87 / 323$ ) is another copy of this photogravure

Provenance: Anonymous donation, 2007

Exhibition history: "Connecting with Photography", Elliott Gallery, AGO, November 14, 2008 - May 24, 2010 


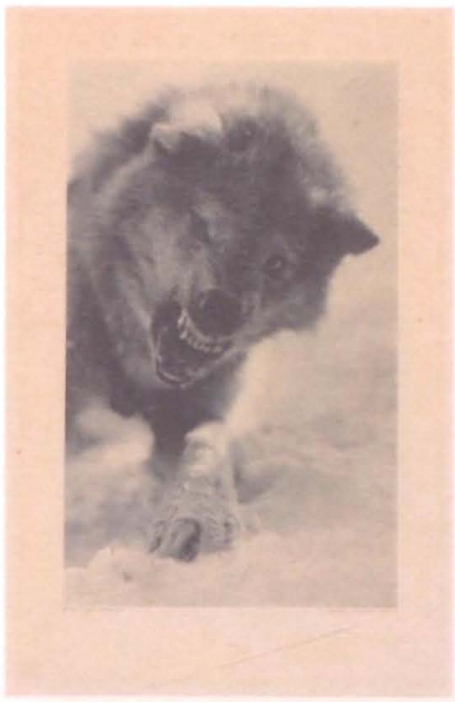

\section{CATALOGUE 35}

\section{AGO accession number: $87 / 324$}

Photographer: Robert J. Flaherty (1884-1951)

Title names: The Huskie, (The Wolf Dog of the Eskimos Documents series (Dog) from Nanook of the North (Imprinted, Published title); Documents series (Dog) (from "Nanook of the North") Published by Revillon Freres (Descriptive, AGO Primary title, Inscribed on matte)

Date of object: 1910-1921 (Negative date);

1922 (Published date)

Date note: "I925 c" previous date for object.

Medium: Photogravure

Dimensions: Image: $21.5 \times 13.1 \mathrm{~cm}(87 / 16 \times 53 / 16 \mathrm{in}$.) Sheet: $39.5 \times 30 \mathrm{~cm}(159 / 16 \times 1 / 13 / 16 \mathrm{in}$.)

Portfolio: Camera Studies of the Far North

Constituents (object related): Publisher: G.P. Putnam's Sons, New York; Image copyright holder: Revillon Frères, New York; Photogravure printer: The American Gravure Company, N.Y.C.

Inscription: (Recto) c.r.: "ROBERT J. FLAHERTY, F.R.G.S." (Imprinted); c.l.:"c (circled) REVILLON FRERES, N.Y." (Imprinted)

\section{Alternate number: AGOID \# 15270}

Notes: Print edges have been trimmed.

Label with title (Imprinted) "The Huskies, (The Wolf Dog of the Eskimos)" has been removed.

Related object at AGO: Catalogue 40 (AGO acc. no. $2007 / 159.2)$ is another copy of this photogravure

Provenance: Gift of Sandra Ball and Marcia Reid, 1987

Exhibition history: None
References (unpublished): The Robert and Frances Study Center, School of Theology. "A Visual Index to the Flaherty Still Photographs: Nanook 000 1-0383." Claremont University http://www.cst.edu/flaherty/VIS_INDEX_NANOOK_000 I.pdf, page I I, frame N329.

Related objects at LAC: There are four related objects on loan from The Robert and Frances Flaherty Study Center at School of Theology, Claremont University, Claremont, California to LAC. All have the same title and LAC reference numbers: Item number 0329; Other accession number 1979-242 NPC; copy negative PAII3520.

I. [Huskie Dog] (Figure 37)

Gelatin silver print.

Image: $7.5 \times 4.5$; Sheet: $12.1 \times 9.5 \mathrm{~cm}$.

Inscription: (Recto) I.r:. "903" (Inscribed in ink); (Verso) u.c.: "N329" (Inscribed in graphite); c: "G" [?] (Inscribed in blue graphite)/ "FN 616 D" (Inscribed in red); I...:"I985105" (Inscribed in graphite).

Note: Residual pieces of black paper glued to back of photograph and upper left corner missing.

\section{2. [Huskie Dog]}

Gelatin silver print. Image (approximately): $20 \times 10 \mathrm{~cm}$; Sheet: $24 \times 14 \mathrm{~cm}$.

Inscriptions: (Recto) I.r.: "53.5/ 48.6" (Inscribed in graphite).

\section{3. [Huskie Dog] (Figure 38)}

Photogravure[?]

Image: $24.1 \times$ 14.9; Sheet: $24.1 \times$ 14.9. Inscriptions: (Recto) I.1.: "G" (Inscribed in red ink); I.r.: "FN 616 D" (Inscribed in red ink).

4. [Huskie Dog]

Photogravure[?] Image: 24.1 × 14.9; Sheet: 24.1 × 14.9 . Inscriptions: (Recto) I.I.:. "G" (Inscribed in red ink); I.r.: "FN 616 D" (Inscribed in red ink).

5. [Huskie Dog]

Photogravure. Image: $21.5 \times 13.1 \mathrm{~cm}$; Sheet: $51.5 \times 33.3$ $\mathrm{cm}$.

Inscriptions: (Recto) c.r.: "ROBERT J. FLAHERTY, F.R.G.S." (Imprinted); c.l.:"c (circled) REVILLON FRERES, N.Y." (Imprinted); I...: "The Huskie"/ (THE WOLF DOG OFTHE ESKIMOS)" (Imprinted). 
(Fig. 37)

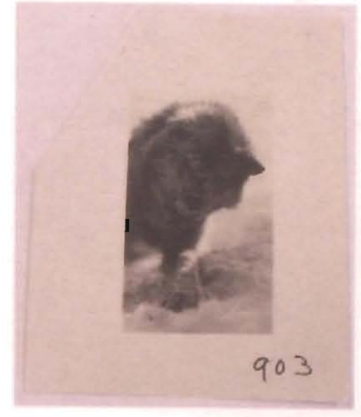

(Fig. 38)

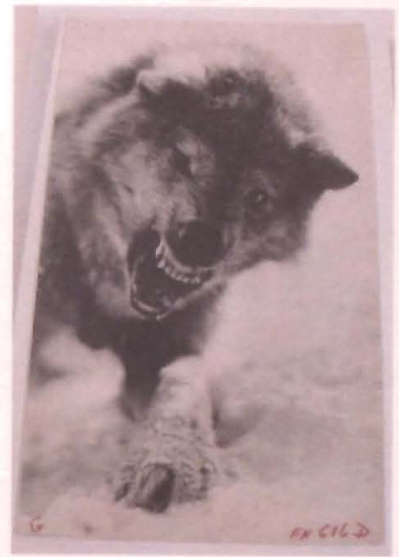

Huskie Dog

(Fig. 44) Gelatin silver print

(Fig. 45) Photogravure [?]

LAC on loan from The Robert and Frances Flaherty

Study Center, School of Theology,

Claremont University, Claremont, California

(Credit: Robert J. Flaherty / Library and Archives of Canada / PA- | | 3520)

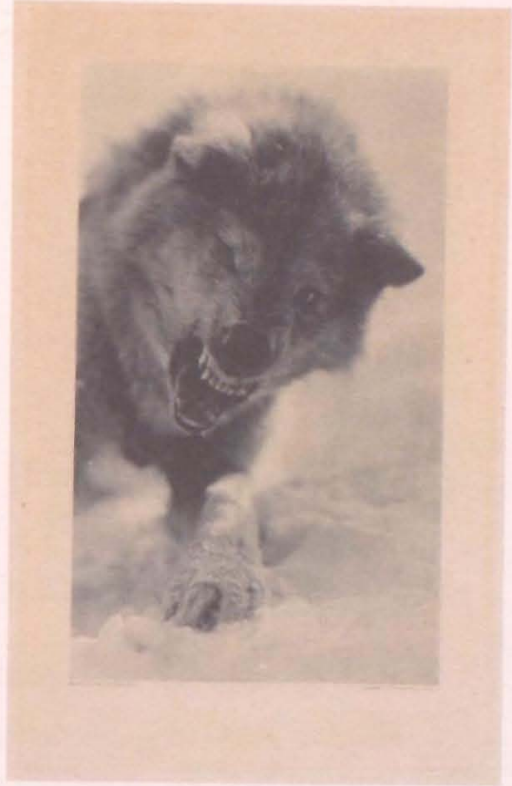

CATALOGUE 40

AGO accession number: $2007 / 159.2$

Photographer: Robert J. Flaherty (1884-1951)

Title names: The Huskie (The Wolf Dog of the Eskimo) (Imprinted, Published title); The Huskie (The Wolf Dog of the Eskimo), from Camera Studies of the Far North (AGO Primary title, Inscribed on matte)

Date of object: 1910-1921 (Negative date);

1922 (Published date)

Date note: "1925 c" previous date for object.

Medium: Photogravure

Dimensions: Image: $21.5 \times 13.1 \mathrm{~cm}(8.5 \times 5.2 \mathrm{in}$.)

Sheet: $49 \times 32.6 \mathrm{~cm}(19.3 \times 12.8 \mathrm{in}$. $)$

Portfolio: Camera Studies of the Far North

Constituents (object related): Publisher: G.P. Putnam's Sons, New York; Image copyright holder: Revillon Frères, New York; Photogravure printer:The American Gravure Company, N.Y.C.

Inscription: (Recto) c.r: ROBERT J. FLAHERTY, F.R.G.S. (Imprinted); c.l.: c (circled) REVILLON FRERES, N.Y. (Imprinted); I..." "THE HUSKIE/ (THEWOLF DOG OF THE ESKIMOS" (Imprinted)

Alternate number: AGOID\# 103420

Related object at AGO: Catalogue 39 (AGO Acc. No. $87 / 324)$ is another copy of this photogravure.

Provenance: Anonymous donation, 2007

Exhibition history: "Connecting with Photography", Elliott Gallery, AGO, November 14, 2008 - May 24, 2010 
References (unpublished): The Robert and Frances Study Center, School of Theology. "A Visual Index to the Flaherty Still Photographs: Nanook 000 I-0383." Claremont University http://wuw.cst.edu/flaherty/ VIS_INDEX_NANOOK_000 I.pdf, page I I, frame N329.

Related objects at LAC: See Catalogue 39 (AGO Acc. No. 87/324) under "Related object(s) at LAC".

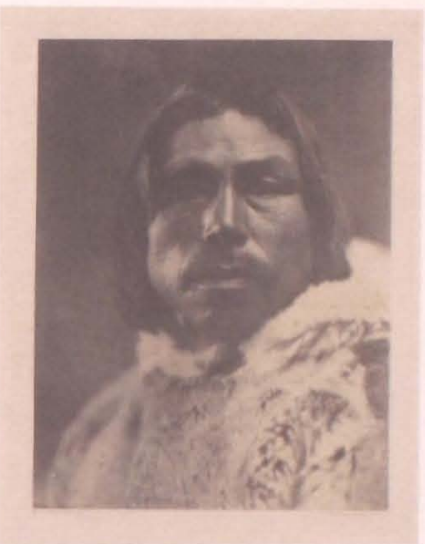

\section{CATALOGUE 4I}

AGO accession number: $92 / 89.8$

Photographer: Robert J. Flaherty ( 884-1951)

Title names: Tooktoo (The Deer), Chief of Sikoslingmint Eskimos, Southern Baffin Land (Imprinted, Published title, AGO Primary title); Tooktoo (the Deer). Chief of Sikoslingmint Eskimos. Southern Baffin Island from Portrait Studies (Inscribed on matte)

Date of object: 1913-1914 (Negative date); 1922 (Published date)

Medium: Photogravure

Dimensions: Image: $21.4 \times 16.5 \mathrm{~cm}(1215 / 16 \times 6$ I/2 $\times$ in.); Sheet: $50.5 \times 33 \mathrm{~cm}(197 / 8 \times 13 \mathrm{in}$.)

Portfolio: Camera Studies of the Far North

Constituents (object related): Publisher: G.P. Putnam's Sons, New York; Image copyright holder: Revillon Frères, New York; Photogravure printer:The American Gravure Company, N.Y.C.

Inscription: (Recto) c.r.: "ROBERT J. FLAHERTY, F.R.G.S." (Imprinted); c.l.:"c (circled) REVILLON FRERES, N.Y.' (Imprinted)

Alternate number: AGOID\# 20776 ; Photo Negative Number $\mathrm{N}-8577$

Notes: Title "Tooktoo (The Deer), Chief of Sikoslingmuit Eskimos, Southern Baffin Land" has been removed.

Identified as Anumniuq. See catalogue by Birnie Danzker page 85 (catalogue 30 ).

Related object at AGO: Catalogue 8 (AGO Acc. No. $93 / 280.5)$ is a silver gelatin print from the same negative, and Catalogue 42 (AGO Acc. No. 2007/I59.1) is another copy of the same photogravure.

Provenance: Gift of Susan Osborn, 1992

Exhibition history: "Robert Flaherty: Camera Studies", AGO, 15 June 1994 - 18 September 1994 
References (unpublished): Flaherty, Robert J. (In collaboration with Frances Hubbard Flaherty.).My Eskimo Friends. Garden City and New York: Doubleday, Page \& Company, 1924, page 58 (illustration).

Birnie Danzker, Jo-Anne. Robert Flaherty, Photographer I Filmmaker: The Inuit I 10-1922.Vancouver, British Columbia:Vancouver Art Gallery, 1979, pages 29, 85 (catalogue 30).

Birnie Danzker, Jo-Anne, "Robert Flaherty/ Photographer", Studies in Visual Communication, 6, No.2, Summer 1980, 18 (illustration and catalogue 30 ).

References (unpublished): The Robert and Frances Study Center, School of Theology." A Visual Index to the Flaherty Still Photographs: Nanook O00 I-0383." Claremont University http://www.cst.edu/flahertyNIS_INDEX_NANOOK_000I.pdf, page 6, frame NI5I.

Related objects at LAC: There are three related objects on loan from The Robert and Frances Flaherty Study Center at School of Theology, Claremont University, Claremont, California to LAC. All have the same LAC reference numbers: Item number 0 I 51 ; Other accession number 1979-242 NPC; copy negative PA- 121985.

1. [Man identified as Anumniuq] (Figure 39) Photogravure[?] on tissue paper Image: $21.5 \times 16.4 \mathrm{~cm}$; Sheet: $24.3 \times 18 \mathrm{~cm}$.

2. [Man identified as Anumniuq] Photogravure[?] on tissue paper Image: $21.4 \times 16.5$; Sheet: $21.4 \times 16.5 \mathrm{~cm}$.

3. [Man identified as Anumniuq] Photogravure. Image: $21.5 \times 16.6$; Sheet: $21.5 \times 16.6 \mathrm{~cm}$. Inscriptions: (Recto) c.r:: "ROBERT J. FLAHERTY, F.R.G.S." (Imprinted); c...."c (circled) REVILLON FRERES, N.Y.' (Imprinted); l.l.: "TOOKTOO/(THE DEER)/Chief of Sikoslingmuit Eskimos/ Southern Baffin Land" (Imprinted).
(Fig. 39)

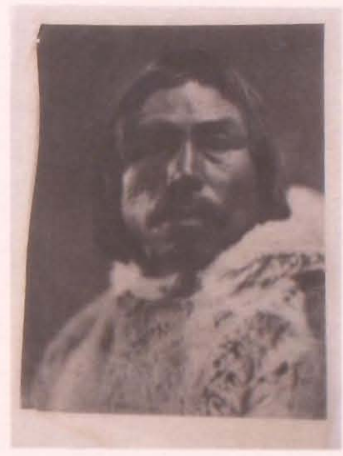

Man identified as Anumniuq

Photogravure [?] on tissue paper

LAC on loan from The Robert and Frances Flaherty

Study Center, School of Theology,

Claremont University, Claremont, Califomia

(Credit: Robert J. Flaherty / Library and Archives of Canada / PA-121985) 


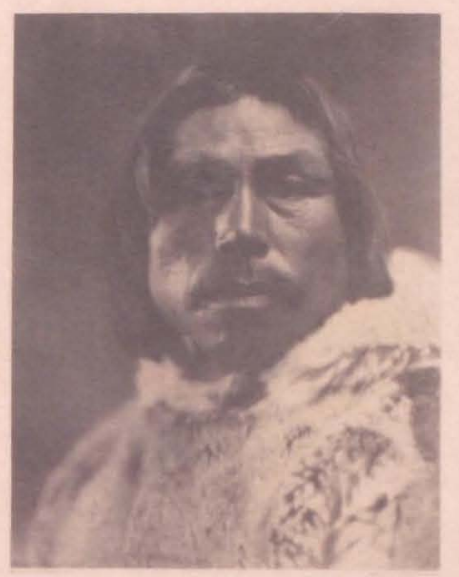

\section{CATALOGUE 42}

AGO accession number: 2007/159.1

Photographer: Robert J. Flaherty (|884-195|)

Title names: Tooktoo (The Deer), Chief of Sikoslingmuit Eskimos, Southern Baffin Land;Tooktoo (The Deer) (Imprinted, Published); Chief of Sikoslingmuit Eskimos, Southern Baffin Island, from Camera Studies of the Far North (Imprinted, AGO Primary title, Inscribed on matte)

Date of object: 1913-1914 (Negative date);

1922 (Published date)

Medium: Photogravure

Dimensions: Image: $21.4 \times 16.5 \mathrm{~cm}(8.4 \times 6.5 \mathrm{in}$.); Sheet: $49.5 \times 32.5 \mathrm{~cm}(19.5 \times 12.8 \mathrm{in}$. $)$

Portfolio: Camera Studies of the Far North

Constituents (object related): Publisher: G.P. Putnam's Sons, New York; Image copyright holder: Revillon Frères, New York; Photogravure printer: The American Gravure Company, N.Y.C.

Inscription: (Recto) c.r.: ROBERT J. FLAHERTY, F.R.G.S. (Imprinted); I.I.: c (circled) REVILLON FRERES, N.Y. (Imprinted)

Alternate number: AGOID \# 103419

Notes: Title "Tooktoo (The Deer), Chief of Sikoslingmuit Eskimos, Southern Baffin Land" has been removed.

Related object at AGO: Catalogue 8 (AGO Acc. No. $93 / 280.5$ ) is a gelatin silver bromide print from the same negative, and Catalogue 41 (AGO Acc. No. 92/89.8) is another copy of this photogravure..

Provenance: Anonymous donation, 2007
Exhibition history: "Connecting with Photography", Elliott Gallery, AGO, November 14, 2008 - May 24, 2010

References (published): Flaherty, Robert J. (In collaboration with Frances Hubbard Flaherty.).My Eskimo Friends. Garden City and New York: Doubleday, Page \& Company, 1924, page 58.

Birnie Danzker, Jo-Anne. Robert Flaherty, Photographer / Filmmaker: The Inuit 1910-1922. Vancouver, British Columbia:Vancouver Art Gallery, 1979, page 85 (catalogue 30).

Bimie Danzker, Jo-Anne, "Robert Flaherty/ Photographer", Studies in Visual Communication, 6, No.2, Summer 1980, 18 (illustration and catalogue 30).

References (unpublished): Flaherty, Robert J. (In collaboration with Frances Hubbard Flaherty.).My Eskimo Friends. Garden City and New York: Doubleday, Page \& Company, 1924, page 58.

Related objects at LAC: See Catalogue 4I (AGO Acc. No. 92/89.8) "Related object(s) at LAC". 


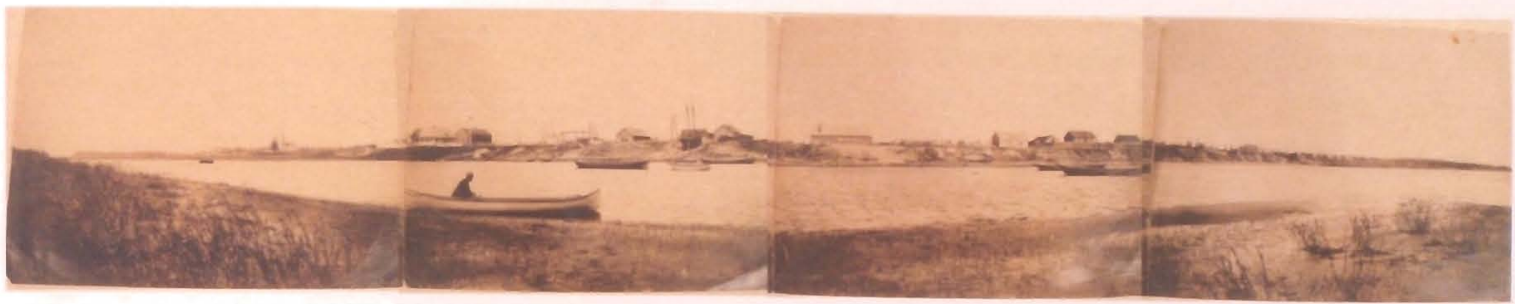

\section{CATALOGUE 43}

AGO accession number: 93/280.21 (Parts 1-4)

Photographer: Robert J. Flaherty (1884-1951)

Title names: Moose Factory (Descriptive, AGO Primary Title, Inscribed on matte)

Date of object: c. 1890 (Negative date)

Date note: Date previously part of title.

Medium: Four gelatin silver bromide prints

Dimensions: Image (Overall): $18.2 \times 99.4 \mathrm{~cm}(7.2 \times 39.1$ in.); Sheet: $18.2 \times 99.4 \mathrm{~cm}(7.2 \times 39.1 \mathrm{in}$.)

Inscription: None

Alternate number: AGOID \# 21793

Notes: Panoramic photograph comprising four prints mounted on board. Donated with album of Flaherty photographs. The album was the donor's possession and was discarded by the AGO.

Related object at AGO: None

Provenance: Gift of Gordon M. Robb, 1993

Exhibition history: "Vital Signs: Part II", Marvin Gelber Gallery, AGO, March 14 - May 26, 1996

References: None

Related object at LAC: None 


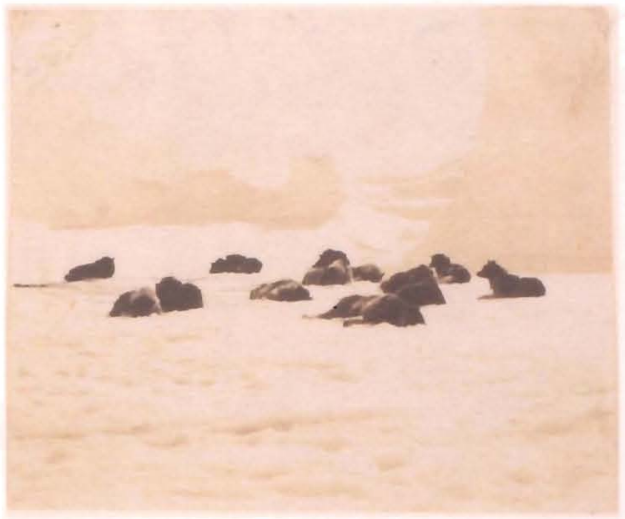

\section{CATALOGUE 44}

AGO accession number: 93/280.22

Photographer: Robert J. Flaherty (1884-195I), attributed to

Photographer note: Photographer was previously unknown, but the same image is deposited at LAC on loan from the Robert and Frances Flaherty Study Center in Claremont, California.

Title name: Huskies on Ice, Hudson's Bay Area (Descriptive); Huskies on Ice (Descriptive, AGO Primary Title, Inscribed on matte)

Title note: Previous title: Huskies on Ice. Geographical location in title taken from LAC.

Date of object: 1910-1916 (Negative date)

Date note: Date taken from LAC website.

Medium: Gelatin silver print

Dimensions: Image: $13.5 \times 11.2 \mathrm{~cm}(4.5 \times 53 / 8 \mathrm{in}$.):

Sheet: $13.5 \times 11.2 \mathrm{~cm}(4.5 \times 53 / 8$ in. $)$

Inscription: None

\section{Alternate number: AGO ID\# 2215 |}

Notes: Originally in album that contained 20 photographs; Album pages are numbered in graphite (as noted by AGO conservator); (Verso) u.r., u.l., I.r., I.I. have residual black paper adhere to sheet. The album was the donor's possession and was discarded by the AGO.

Related object at AGO: None

Provenance: Gift of Gordon M. Robb, 1993

Exhibition history: None
References (unpublished): The Robert and Frances Study Center, School of Theology. "A Visual Index to the Flaherty Still Photographs: Nanook 200 I-2416." Claremont University http://umw.cst.edu/flahertyNIS_INDEX_NANOOK_2001.pdf, page I I, frame N2318.

Related object at LAC: Dog Team Resting in Snow Gelatin silver print. Image: $10.8 \times 13.6 \mathrm{~cm}$; Sheet: $10.8 \times$ $13.6 \mathrm{~cm}$.

Inscription: (Verso) u.r.: "N2318" inscribed in graphite/ " $G$ " inscribed in inki c: "117" scribbled out/ " 847 " in graphite; I.I.: "I985-105" in graphite; I.c.:. "PA-14351 I" in graphite.

Note: Light brown paper adhered to back of photograph.

LAC reference numbers: Item number 2318; Other Accession Number 1985-105 NPC; Copy negative PA-143511. On loan from The Robert and Frances Flaherty Study Center, School of Theology, Claremont University, Claremont, California. 


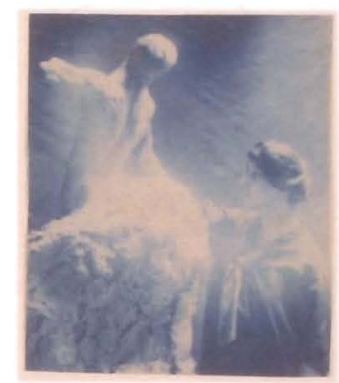

\section{CATALOGUE 45}

AGO accession number: $86 / 112$

Photographer: Robert J. Flaherty (1884-1951), attributed to

Title name: Frances Loring (Descriptive, AGO Primary title)

Date of object: 1914-1915 (Negative date)

Date note: Previous date: 1919 c. Maia-Mari Sutnik, AGO curator of photography, in a research note dated 17 January 2000 in registration file of Accession number $86 / 1 / 4$ cited that Flaherty was in Toronto during the late fall of 1914 and remained in there for the duration of his photography exhibition and screening of Nanook of the North at the Arts \& Letters Club of Toronto in January 1915 and also at Convocation Hall, University of Toronto on March 30, 1915. This corroborates with a diary entry of Frances Flaherty's reprinted in Robert J. Christopher's Robert and Frances Flaherty: A Documentary Life, 1883-1922, Kingston and Montreal: McGillQueen's University Press, 2005, p.225, which state that she and Robert Flaherty first met Loring and Wyle in December 1914 .

Medium: Cyanotype

Dimensions: Image: $15 \times 12.5 \mathrm{~cm}(57 / 8 \times 4 / 5 / 16 \mathrm{in}$.$) ;$ Sheet: $15 \times 12.5 \mathrm{~cm}(57 / 8 \times 415 / 16 \mathrm{in}$. $)$

Inscription: None

Alternate number: AGO ID\# 12414

Notes: Uneven edges of the photograph indicate that the photograph was trimmed by hand.

Related object at AGO: See Catalogue 46-5I.

Provenance: Gift of the Estates of Frances Loring and Florence Wyle, 1983

Exhibition history: "In Situ: Photographic Studies of Artists", Rotman Gallery, AGO, September 4 - December 2004
Bibliography: Sisler, Rebecca. The Girls: A Biography of Frances Loring and Florence Wyle. Toronto: Clark, Irwin \& Company, 1972. [References to Flaherty on pages $10,28,87]$.

Cameron, Elspeth. And Beauty Answers: The Life of Frances Loring and Florene Wyle. Toronto: Cormorant Books, 2007. [References to Flaherty on pages $97,98,188]$.

Christopher, Robert J., Robert and Frances Flaherty: A Documentary Life, 1883-1922. Montreal, Quebec: McGill-Queen's University Press, 2005. [Reference to the Flahertys and photograph of Loring and Wyle on page 256].

\section{References: None}

Related object(s) at other institutions: Unknown at this time. 


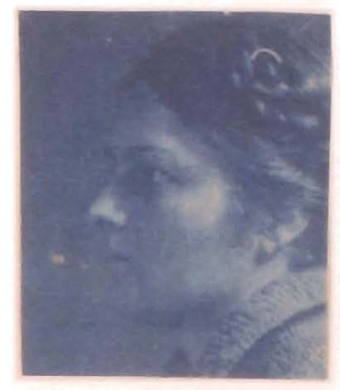

\section{CATALOGUE 46}

\section{AGO accession number: $86 / 1$ | 3}

Photographer: Robert J. Flaherty (|884-|95|), attributed to

Title name: Profile of Florence Wyle (Descriptive, AGO Primary title)

Date of object: 1914-1915 (Negative date)

Date note: Previous date: 1919 c. Maia-Mari Sutnik, AGO curator of photography, in a research note dated 17 January 2000 in registration file of Accession number 86/1 I4 cited that Flaherty was in Toronto during the late fall of 1914 and remained in there for the duration of his photography exhibition and screening of Nanook of the North at the Arts \& Letters Club of Toronto in January 1915 and also at Convocation Hall, University of Toronto on March 30, 1915. This corroborates with a diary entry of Frances Flaherty's reprinted in Robert J. Christopher's Robert and Frances Flaherty:A Documentary Life, I883-1922, Kingston and Montreal: McGillQueen's University Press, 2005, p.225, which state that she and Robert Flaherty first met Loring and Wyle in December 1914 .

\section{Medium: Cyanotype}

Dimensions: Image: $9.4 \times 7.8 \mathrm{~cm}(31 / / 16 \times 31 / 16 \mathrm{in}$.) Sheet: $9.4 \times 7.8 \mathrm{~cm}(311 / 16 \times 31 / 16 \mathrm{in}$. $)$

Inscription: None

\section{Alternate number: AGO ID\# |24I5}

Notes: Uneven edges of the photograph indicate that the photograph was trimmed by hand.

Related object at AGO: See Catalogue 45, 47-5I.

Provenance: Gift of the Estates of Frances Loring and Florence Wyle, 1983

\section{Exhibition history: None}

Bibliography: Sisler, Rebecca. The Girls: A Biography of Frances Loring and Florence Wyle. Toronto: Clark, Irwin \& Company, 1972. [References to Flaherty on pages $10,28,877$.

Cameron, Elspeth. And Beauty Answers: The Life of Frances Loring and Florene Wyle. Toronto: Cormorant Books, 2007. [References to Flaherty on pages 97,98, 188].

Christopher, Robert J., Robert and Frances Flaherty: A Documentary Life, 1883-1922. Montreal, Quebec: McGill-Queen's University Press, 2005. [Reference to the Flahertys and photograph of Loring and Wyle on page 256].

References: Koltun, Lilly. "In Your own Drama, You are the Star: Portraiture of Subjects Drawn From Cultural Life in Canadian Photography, c. 1895 - 1955." PhD diss., St. Andrews University, 1997. [As per Image Reproduction Form in Registration File for this object].

Related object(s) at other institutions: Unknown at this time. 


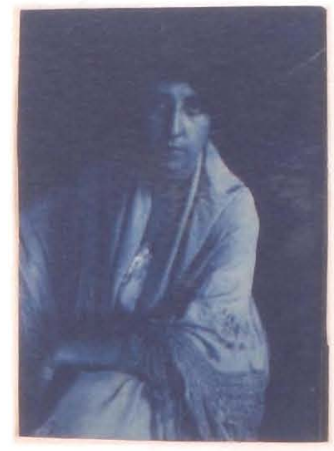

\section{CATALOGUE 47}

\section{AGO accession number: $86 / 111$}

Photographer: Robert J. Flaherty (1884-1951), attributed to

Title name: Frances Loring with Shawl (Descriptive, AGO Primary Title); 3/4 portrait of Frances Loring (Inscribed on matte)

Date of object: 1914-1915 (Negative date)

Date note: Previous date: 1919 c. Maia-Mari Sutnik, AGO curator of photography, in a research note dated 17 January 2000 in registration file of Accession number $86 / 114$ cited that Flaherty was in Toronto during the late fall of 1914 and remained in there for the duration of his photography exhibition and screening of Nanook of the North at the Arts \& Letters Club of Toronto in January 1915 and also at Convocation Hall, University of Toronto on March 30, 1915. This corroborates with a diary entry of Frances Flaherty's reprinted in Robert J. Christopher's Robert and Frances Flaherty: A Documentary Life, $1883-$ 1922, Kingston and Montreal: McGill-Queen's University Press, 2005, p.225, which state that she and Robert Flaherty first met Loring and Wyle in December 1914.

Medium: Cyanotype

Dimensions: Image: $19.3 \times 14.4 \mathrm{~cm}(75 / 85 \times 11 / 16$ in.); Sheet: $19.3 \times 14.4 \mathrm{~cm}(75 / 8 \times 51 / / 16 \mathrm{in}$.)

Inscription: None

\section{Alternate number: AGO ID\# 12413}

Notes: (Recto):There is a white line along the right edge of the photograph which indicates that it was printed from a glass plate negative using the contact printing method.

Related object at AGO: I. Frances Loring 1914-1915 (Figure 40) Gelatin silver print.

Image: $21.4 \times 16.3 \mathrm{~cm}$; Sheet: $22 \times 17 \mathrm{~cm}$.

E.P Taylor Research Library and Archives, Special Collections: Frances Loring and Florence Wyle fonds, Series I I: Photographs, box 15 - Loring and Wyle biographical (matted). [This object does not have an item number].
Note:The date in this title is given as c.1919 in the library records, but in light of the above information in Date notes, this date now is incorrect.

2. Catalogue 48 (AGO Acc. No. 86/I I5). Printed from the same negative as catalogue 47 , but has been enlarged and cropped.

See also catalogue 45,46, 48-5I.

Provenance: Gift of the Estates of Frances Loring and Florence Wyle, 1983

Exhibition history: "Recent Acquisitions Canadian Historical Works on Paper: Staffage to Centre Stage: The Figure in Canadian Art", Tom Thompson Memorial Art Gallery, Owen Sound and circulated to other galleries (organized by the AGO), May $5-28,1989$

Bibliography: Sisler, Rebecca. The Girls: A Biography of Frances Loring and Florence Wyle. Toronto: Clark, Irwin \& Company, 1972. [References to Flaherty on pages 10,28, 87].

Cameron, Elspeth. And Beauty Answers:The Life of Frances Loring and Florene Wyle. Toronto: Cormorant Books, 2007. [References to Flaherty on pages 97,98, I88].

Christopher, Robert J., Robert and Frances Flaherty: A Documentary Life, I883-1922. Montreal, Quebec: McGill-Queen's University Press, 2005. [Reference to the Flahertys and photograph of Loring and Wyle on page 256].

References: None

Related object(s) at other institutions: Unknown at this time.

(Fig. 40)

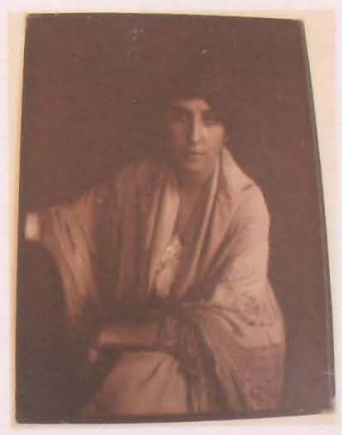

Frances Loring 1914-1915

Gelatin silver print

AGO, E.P Taylor Research Library and Archives, Special Collections 


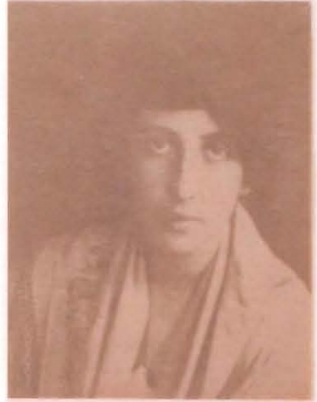

\section{CATALOGUE 48}

AGO accession number: $86 / 1 / 5$

Photographer: Robert J. Flaherty (|884-1951). attributed to

Title name: Portrait - Frances Loring (Descriptive, Inscribed on matt, AGO Primary title)

Date of object: 1914-1915 (Negative date)

Date note: Previous date: 1919 c. Maia-Mari Sutnik, AGO curator of photography, in a research note dated 17 January 2000 in registration file of Accession number 86/ I I 4 cited that Flaherty was in Toronto during the late fall of 1914 and remained in there for the duration of his photography exhibition and screening of Nanook of the North at the Arts \& Letters Club of Toronto in January 1915 and also at Convocation Hall, University of Toronto on March 30, 1915. This corroborates with a diary entry of Frances Flaherty's reprinted in Robert J. Christopher's Robert and Frances Flaherty: A Documentary Life, 1883-1922, Kingston and Montreal: McGillQueen's University Press, 2005, p.225, which state that she and Robert Flaherty first met Loring and Wyle in December 1914 .

Medium: Toned Cyanotype (brown)

Medium note: The process for this photograph remains inconclusive, however it is very likely a cyanotype according to AGO photography Curator, Maia-Mari Sutnik and Photography conservator, Katherine Whitman.

Dimensions: Image: $11.4 \times 8.9 \mathrm{~cm}(41 / 2 \times 31 / 2 \mathrm{in}$.); Sheet: $11.4 \times 8.9 \mathrm{~cm}(41 / 2 \times 31 / 2 \mathrm{in}$.

Inscription: None

Alternate number: AGO ID\# 12417

Related object at AGO: Catalogue 47(AGO Acc. No. $86 / 111$ ) was printed from the same negative, but this image (catalogue 48) has been enlarged and cropped.

See also catalogue 46-47, 49-51

Provenance: Gift of the Estates of Frances Loring and Florence Wyle, 1983

\section{Exhibition history: None}

Bibliography: Sisler, Rebecca. The Girls: A Biography of Frances Loring and Florence Wyle. Toronto: Clark, Irwin \& Company, 1972. [References to Flaherty on pages 10 , $28,87]$.

Cameron, Elspeth. And Beauty Answers: The Life of Frances Loring and Florene Wyle. Toronto: Cormorant Books, 2007. [References to Flaherty on pages 97,98, 188].

Christopher, Robert ]., Robert and Frances Flaherty: A Documentary Life, 1883-1922. Montreal, Quebec: McGill-Queen's University Press, 2005. [Reference to the Flahertys and photograph of Loring and Wyle on page 256].

References: Koltun, Lilly. "In Your own Drama, You are the Star: Portraiture of Subjects Drawn From Cultural Life in Canadian Photography, c. 1895 - 1955." PhD diss., St. Andrews University, 1997. [As per Image Reproduction Form in Registration File for this object].

Related object(s) at other institutions: Unknown at this time. 


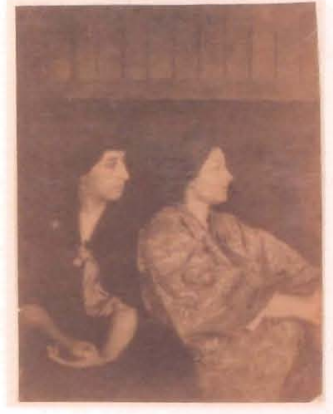

\section{CATALOGUE 49}

AGO accession number: $86 / 1 / 6$

Photographer: Robert J. Flaherty (| 884-195|), attributed to

Title name: Portrait of Frances Loring and Florence Wyle (Church Street, Toronto) (Descriptive, AGO Primary title); Portrait-Frances Loring and Florence Wyle (Inscribed on matt, AGO Assigned title)

Date of object: 1914-1915 (Negative date)

Date note: Previous date: 1914. Maia-Mari Sutnik, AGO curator of photography, in a research note dated 17 January 2000 in registration file of Accession number $86 / 114$ cited that Flaherty was in Toronto during the late fail of 1914 and remained in there for the duration of his photography exhibition and screening of Nanook of the North at the Arts \& Letters Club of Toronto in January 1915 and also at Convocation Hall, University of Toronto on March 30, 1915. This corroborates with a diary entry of Frances Flaherty's reprinted in Robert J. Christopher's Robert and Frances Flaherty: A Documentary Life, I 883-1922, Kingston and Montreal: McGillQueen's University Press, 2005, p.225, which state that she and Robert Flaherty first met Loring and Wyle in December 1914 .

Medium: Toned gelatin silver bromide print

Dimensions: Image: $21 \times 16.1 \mathrm{~cm}(81 / 4 \times 65 / 16 \mathrm{in}$.); Sheet: $21 \times 16.1 \mathrm{~cm}(81 / 4 \times 65 / 16 \mathrm{in}$. $)$ Inscription: (Verso): "Loring \& Wyle - Bob Flaherty 1919" (Inscribed in ink)

Alternate number: AGOID \# 12418; Photo Negative number $\mathrm{N}-6264$

Notes: (Recto): I.c.: Corner of photograph torn; u.c.: dark brown spots
Related object at AGO: Catalogue 5 I (AGO Acc. No $86 / 1$ 14) was printed from the same negative, but has been enlarged and cropped.

Catalogue 50 (AGO Acc. No. 86/1 17) was printed from the same negative.

See also Catalogue 46-48 and 50-51.

Provenance: Gift of the Estates of Frances Loring and Florence Wyle, 1983

Exhibition history: "Symbolism and Secession: A Selection of Photographs", AGO, February 7 - May 1995

Bibliography: Sisler, Rebecca. The Girls: A Biography of Frances Loring and Florence Wyle. Toronto: Clark, Irwin \& Company, 1972. [References to Flaherty on pages $10,28,87]$.

Cameron, Elspeth. And Beauty Answers: The Life of Frances Loring and Florene Wyle. Toronto: Cormorant Books, 2007. [References to Flaherty on pages 97,98, 188].

Christopher, Robert J., Robert and Frances Flaherty: A Documentary Life, 1883-1922. Montreal, Quebec: McGill-Queen's University Press, 2005. [Reference to the Flahertys and photograph of Loring and Wyle on page 256].

References: Koltun, Lilly. "In Your own Drama, You are the Star: Portraiture of Subjects Drawn From Cultural Life in Canadian Photography, c. 1895 - 1955." PhD diss., St. Andrews University, 1997. [As per Image Reproduction Form in Registration File for this object].

Related object(s) at other institutions: Unknown at this time. 


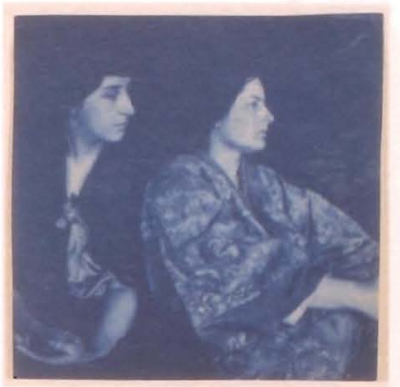

\section{CATALOGUE 50}

\section{AGO accession number: $86 / 1 / 6$}

Photographer: Robert J. Flaherty (1884-1951),

attributed to

Title name: Portrait of Frances Loring and Florence Wyle (Church Street, Toronto) (Descriptive, AGO Primary title); Portrait-Frances Loring and Florence Wyle (Inscribed on matt, AGO Assigned title); Frances Loring and Florence Wyle (Published title)

Date of object: 1914-1915 (Negative date)

Date note: Previous date: 1914 (1919 c. inscribed on matte). Maia-Mari Sutnik, AGO curator of photography, in a research note dated 17 January 2000 in registration file of Accession number $86 / 114$ cited that Flaherty was in Toronto during the late fall of 1914 and remained in there for the duration of his photography exhibition and screening of Nanook of the North at the Arts \& Letters Club of Toronto in January 1915 and also at Convocation Hall, University of Toronto on March 30, 1915. This corroborates with a diary entry of Frances Flaherty's reprinted in Robert J. Christopher's Robert and Frances Flaherty: A Documentary Life, 1883-1922, Kingston and Montreal: McGill-Queen's University Press, 2005, p.225, which state that she and Robert Flaherty first met Loring and Wyle in December 19/4.

\section{Medium: Cyanotype}

Dimensions: Image: $14.5 \times 14.7 \mathrm{~cm}(5$ 1 //16 $\times 5$ 13/16 in.) Sheet: $14.5 \times 14.7 \mathrm{~cm}(51 / / 16 \times 5$ /3/16 in.)

Inscription: (Verso): "Photo/ taken by Bob Flaherty/ before 1920" (Inscribed in graphite)

Alternate number: AGO ID \# 12419; Photo Negative number N-6263

Notes: Uneven edges of the photograph indicate that the photograph was trimmed by hand.
Related object at AGO: Catalogue 5 I (AGO Acc. No. 86/ I 14) was printed from the same negative, but has been enlarged and cropped to Wyle's face (on the right. Catalogue 49 (AGO Acc. No. 86/1/6) was printed from the same negative.

See also Catalogue 46-49, 51.

Provenance: Gift of the Estates of Frances Loring and Florence Wyle, 1983

Exhibition history: "Loring and Wyle: Sculptor's Legacy", AGO, July 24-October 181987

Bibliography: Sisler, Rebecca. The Girls: A Biography of Frances Loring and Florence Wyle. Toronto: Clark, Irwin \& Company, 1972. [References to Flaherty on pages 10 , $28,87]$.

Cameron, Elspeth. And Beauty Answers: The Life of Frances Loring and Florene Wyle. Toronto: Cormorant Books, 2007. [References to Flaherty on pages 97,98 , 188].

Christopher, Robert J., Robert and Frances Flaherty: A Documentary Life, 1883-1922. Montreal, Quebec: McGill-Queen's University Press, 2005. [Reference to the Flahertys and photograph of Loring and Wyle on page 256].

References (published): Cameron, Elspeth. And Beauty Answers: The Life of Frances Loring and Florence Wyle. Toronto: Cormorant Books, 2007. [Photograph (tone altered) appears on the book cover; Prentice, Alison L. et al.

Canadian Women: A History. Ist and 2nd ed. Toronto; Orlando: Harcourt Brace Jovanovich, 1988; Toronto: Harcourt Brace Canada, 1996. [As per Image Reproduction Form in Registration File];

[Both references as per Image Reproduction Forms in Registration File for this photograph].

References (unpublished): National Ballet of Canada, (ballet program), April 26, 1988. [As per Image Reproduction Forms in Registration File for this photograph].

Related object(s) at other institutions: Unknown at this time. 


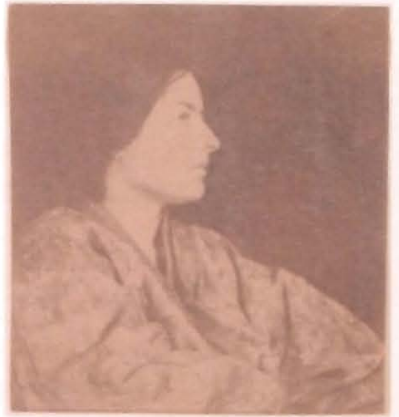

\section{CATALOGUE 5 I}

AGO accession number: $86 / 116$

Photographer: Robert J. Flaherty ( 884 - 195 I), attributed to

Title name: Portrait of Florence Wyle (Church Street, Toronto) (Descriptive, AGO Primary title); Portrait-Florence Wyle (Inscribed on matte, AGO Assigned title)

Date of object: 1914-1915 (Negative date)

Date note: Previous date: 1914. Maia-Mari Sutnik, AGO curator of photography, in a research note dated 17 January 2000 in registration file of Accession number 86/1 I and Elspeth Cameron, And Beauty Answers: The Life of Frances Loring and Florence Wyle. (Toronto: Cormorant Books inc., 2007), 98 both suggest that portraits taken of Loring (and Florence Wyle) by Flaherty would have been around the time of the screening of his film Nanook of the North at Convocation Hall, University of Toronto on March 30, 1915.

Medium: Toned Cyanotype (brown)

Medium note: The process for this photograph remains inconclusive, however it is very likely a cyanotype according to AGO Photography Curator, Maia-Mari Sutnik and Photography conservator, Katherine Whitman.

Dimensions: Image: $9.1 \times 8.5 \mathrm{~cm}(39 / 16 \times 33 / 8 \mathrm{in}$.); Sheet: $9.1 \times 8.5 \mathrm{~cm}(39 / 16 \times 33 / 8 \mathrm{in}$. $)$

Inscription: (Verso): "Photo/ taken by Bob Flaherty/ before 1920" (Inscribed in graphite)

Alternate number: AGO ID \# 12416

Notes: Uneven edges of the photograph indicate that the photograph was trimmed by hand.
Related object at AGO: Catalogue 49 (AGO Acc. No. 86/1 16) and Catalogue 50 (AGO Acc. No.86/1 /7).

Both of these images were printed from the same negative as this object, but these show the full negative. This image (catalogue 5I) appears to be an enlarged detail.

See Catalogue 46-50.

Provenance: Gift of the Estates of Frances Loring and Florence Wyle, 1983

\section{Exhibition history: None}

Bibliography: Sisler, Rebecca. The Girls: A Biography of Frances Loring and Florence Wyle. Toronto: Clark, Irwin \& Company, 1972. [References to Flaherty on pages $10,28,87]$.

Cameron, Elspeth. And Beauty Answers: The Life of Frances Loring and Florene Wyle. Toronto: Cormorant Books, 2007. [References to Flaherty on pages 97,98, 188].

Christopher, Robert J., Robert and Frances Flaherty: A Documentary Life, 1883-1922. Montreal, Quebec: McGill-Queen's University Press, 2005. [Reference to the Flahertys and photograph of Loring and Wyle on page 256].

\section{References: None}

Related object(s) at other institutions: Unknown at this time. 


\section{Analysis of selected works by Robert J. Flaherty from the AGO}

This section provides an analysis of three works by Flaherty in the AGO collection: a photogravure from the portfolio, Camera Studies of the North, and two gelatin silver photographs. Each of these works was selected from one of the three groupings in the Flaherty collection: Photographs of northern scenes and portraits of the Inuit; photographs of northern scenes whose maker is unknown but that are associated with the work of Flaherty at AGO; and portraits of Frances Loring and Florence Wyle.

The analysis is based on the research that is found in the catalogue. As the focus of this thesis is the catalogue and because of time constraints, it was only possible to study three works in detail in order to demonstrate the value of the catalogue and the information it possesses.

\section{Photographing in the North from 1910-1916 and 1921-1922}

The source of information about Flaherty's photographing activity during his expeditions to the North is derived principally from his diaries. Numerous entries indicate that he photographed the landscape and made portraits as early as 1910, during his first expedition to the Nastapoka Islands: ${ }^{64}$

On September 7, 1910 (a month into the first trip) he wrote, "[t]ook photos and developed very good photos of the place and people." Many entries regarding picture taking are briefly recorded, often written in one sentence or less. Another entry from September 27, 1910 reads, "Took three pictures." In most entries, Flaherty does not

\footnotetext{
64 Photographs appear in Robert J. Flaherty, "The Belcher Islands of Hudson Bay: Their Discoveries and Exploration," Geographical Review. Vol. 5, No. 6 (June 1918): 433-458. American Geographical Society. http://www.jstor.org/stable/207804 (accessed October 13, 2009) and "Two Traverses Across the Ungava Peninsula, Labrador", The Geographical Review, vol. VI, no.2 (August 1918): 116-132. http://www.jstor.org/stable/207475 (accessed February 13, 2010).
} 
mention either the specific names of the people or the subjects he photographed; although in some instances he did identify the person and his or her ethnic group. For example, in his entry for December 20, 1910, he wrote "... at Indian camp, took picture there of Indian boy...,

References to picture taking and developing in his diaries become fewer in the third (1913-1914) and fourth (1915-1916) expeditions. This is probably due to the fact his filming activities began during his third expedition. However, the references in his diaries certainly do not account for all of the surviving negatives.

For cameras, he brought two types of cameras, a " 5 x 4 Eastman plate and a $4 \times 5$ Graflex with two hundred exposures" ${ }^{96}$ on his second expedition (6 June $11-8$ August 1912). ${ }^{67}$ On the third expedition he brought a "Graflex Camera, 4 x 5, six dozen plates, one film camera, $3 \frac{1 / 4}{4} 4 \frac{1}{4}$, twenty five films, one tripod." 68 This equipment corresponds to the sizes of the glass plate and nitrate negatives examined at LAC.

In a report written by Dr. Michèle Therrien for the Revillon (Frères) Archives regarding Flaherty's photographic albums,${ }^{69}$ Therrien states that photographs were taken at Fort George (Chisasibi) in James Bay (1910-1912); Fort Chimo (Kuujuaq) in Ungava Bay (1912); Amaduak in the southeast of Baffin Island (1913-1914), Qikiqtait in Hudson Bay (1915-1916) and Port Harrison (Inujjuaq) in Hudson Bay (1920-1921). ${ }^{70}$

\footnotetext{
65 Robert Christopher, Robert and Frances Flaherty, 50-51, 55.

66 In Europe, $4 \times 5$ formats are usually expressed with the larger number first as " $5 \times 4$ ". It is unknown why Flaherty expressed his "Eastman plate" (camera manufactured by Eastman Kodak Company) with the larger number first.

67 Ibid, 91.

${ }^{68} \mathrm{Ibid}, 175$.

${ }^{69}$ Michèle Therrien "Archives Revillon Photos, Inventaire Analytique" (Photocopy, Archives Publiques du Canada, Paris, February 1984).

70 Ibid, 3.
} 
The report also identifies the names of the subjects whose photograph appear in the Revillon Frères albums: Nyla (Alice Nuvalinga), woman in the fillm, Nanook, Canayou (Kanajuq), the girl; Allego, sister of Nyla and Phillipoosie, the child who is holding the bow and arrow in Album $1 .^{71}$ These names appear in the titles of the photogravures at AGO confirming their identity.

\section{Analysis of the negative, photograph and photogravure}

Flaherty's Inuit portraits appear to conform to two types - "Studio-type" or "confrontation", as proposed by Birnie Danzker in 1979. "Studio-type" portraits refer to the conventional practice of portraiture in the nineteenth century; the sitter is "carefully posed, side-lit, occasionally in profile, and their eyes rarely meet the camera." ${ }^{72}$ In "confrontation" portraits, the subject looks directly at the camera, confronting the viewer (examples of "confrontation" portraits are in catalogues 12 and 15). An example of a "studio-type" portrait will be discussed and used to understand Flaherty's method of working and of photographic production from negative to photograph to photogravure.

The studio portrait of Sapa, Sikoslingmint Eskimo of Southern Baffin Land (Fig.41) displays high-density tonal areas with light directed from the left, lighting the side of the subject's face and shoulder, revealing a fur hood and clothing around one side of his head, shoulder, and chest areas. Upon closer inspection, the photograph is softfocus; that is, no part of the portrait is in sharp focus. The glass plate negative appears to have approximately the same degree of 'blurriness' (fig. 42). The negative also reveals that there was no retouching on the negative to alter the tones of the print. The largest and

\footnotetext{
71 The correct names of the people in the photogravures are indicated in Birnie Danzker's catalogue in the Exhibition Index.

72 Jo-Anne Bimie Danzker, Robert Flaherty, 26
} 
most obvious difference between the two is the significant amount of cropping that Flaherty made when he printed the photograph; in the lower right corner of the negative (verso) one can see more background and more of the sitter's right upper arm.

Much of the 'darkness' surrounding the sitter in the print is explained by the description of Flaherty's "photography studio" as recalled by Simonie, a Baffin Island resident, in an interview with Dorothy Harley Eber, the author of "On Koodjuk's Trail". He recalled a portrait session in 1914:

They had to take them inside, in Flaherty's house. I don't recall them having flashes with the camera. They used kerosine lanterns, and I remember three lanterns being placed in special places on the wall. I remember a camera with a cloth that had to go over the head. Maybe that was because they had to prevent any light coming to the photographer's vision. It took a long time before the photographer could actually take a picture. They had to relax him first. The man sitting on the chair had to be very relaxed...If he was liable to move at all they couldn't take this picture. That's what I remember. ${ }^{73}$

The production of these "studio-type" portraits taken inside Flaherty's make-shift studio resulted in photographs that were purposely underexposed, making them appear darker. Also, as this negative (fig. 42) and the other glass plate negatives, such as Unidentified (Young Woman), Baffin Island (catalogue 1) reveals, the negatives were taken with softfocusing at the time of shooting. It is evident that Flaherty purposely used this technique to produce the effect he wanted.

The use of soft-focus photographs is associated with the photographic art movement pictorialism, which was widely adopted around the end of the nineteenth century. ${ }^{74}$ The pictorialists favoured this style largely because it the made photographs look more artistic and painterly, but it is unknown when Flaherty adopted this and whose

73 Dorothy Harley Eber, "On Koodjuk's Trail", Natural History 88 (January 1979), 81 reprinted in JoAnne Birnie Danzker, Robert Flaherty, 25 and Robert J. Christopher, Robert and Frances Flaherty, 215. 
work had influenced his own photographs. According to the diary of Frances Flaherty, the Flahertys met Edward Curtis and Alfred Steiglitz in New York in April 1915. The meeting with Curtis was related to the Flahertys' attempt to find a distributor for the 1914 film 75 and it was screened alongside Curtis' film of Salish Indians to "an audience of experts." ${ }^{276}$ At this meeting, they had the opportunity to see that Curtis' portfolios of Indian portraits, which gave Frances Flaherty the idea that the Inuit portraits could be profitable if sold as a portfolio set as well. ${ }^{77}$ Frances Flaherty also described their meeting with Steiglitz at " 291 " gallery in a slightly later diary entry. The Flahertys had seen Steglitz's periodical Camera Work and they asked him to look at the Inuit portraits. The feedback Stieglitz gave was positive but his reaction doesn't clarify whether or not the portraits were the pictorialist ones.

In comparing the photogravure (fig. 43: catalogue 30 ) to the photograph, it is very likely that the gravure plate was retouched, as the subject has more highlights on the right side of his face, which appears lighter than in the photograph. However one cannot verify during which of the five stages of the photogravure process the plate was retouched, since neither the copper plates nor the printing company exist any longer. ${ }^{78}$

The three related objects shown here together - negative, photograph and photogravure - demonstrate the production method of Flaherty's photographic practice from the period of 1910-1916. He photographed his subjects in a studio environment using a $4 \times 5$ camera and glass plate negatives. He employed dim lighting to produce an

\footnotetext{
75 The 1914 film was made during the third expedition (1913-1914), but was never released in theatres.

76 Robert Christopher, Robert and Frances Flaherty, 243.

77 Ibid, 242.

78 In Sutnik and Dewan's research file on Flaherty, a fax copy of an e-mail from an unidentified person to Sue Wehmeyer at Waddingtons Auction (now defunct) indicates that the photogravure printer was The American Gravure Company, N.Y.C.
} 
underexposed negative that would yield a darker print which was used to enhance the effects of pictorialism. For printing, the image is enlarged of the negative and closely cropped to the subject's face, omitting the area surrounding the subject's head, upper arm and a bit of his chest. In printing the gravure, the image followed the cropping of the photograph, rather than the full negative. ${ }^{79}$

(Fig.41)

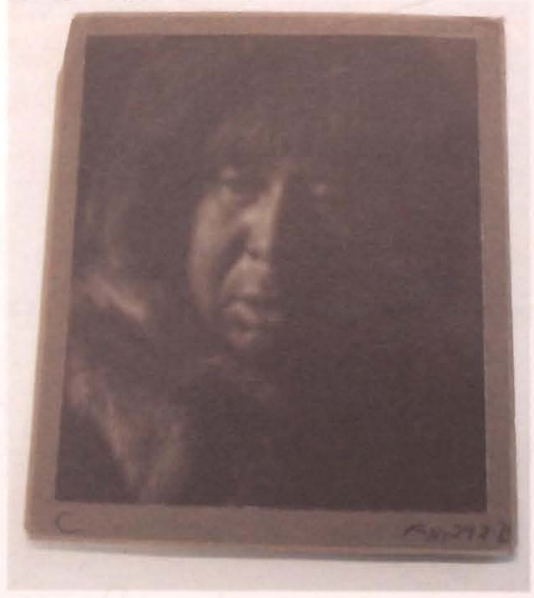

(Fig.42)

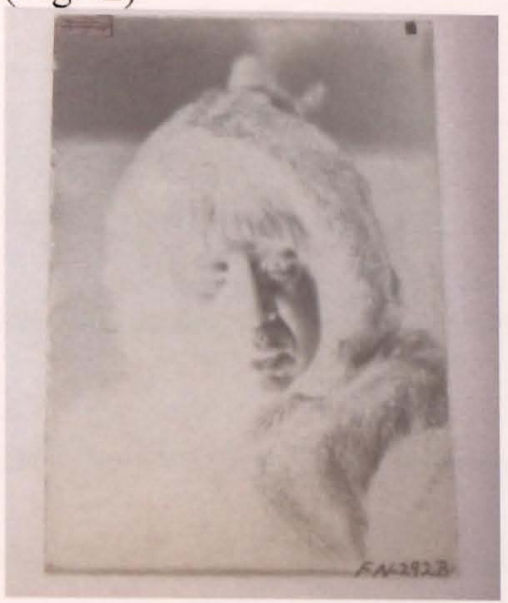

(Fig.41) [Man identified as Sapa]

Gelatin silver bromide print

Image: $19.8 \times 17 \mathrm{~cm}$; Sheet: $19.8 \times 17 \times \mathrm{cm}$;

Mat 1: $22 \times 18.8 \mathrm{~cm}$; Mat 2: $22.4 \times 19.4 \times \mathrm{cm}$

(Fig.42) [Man identified as Sapa]

Gelatin silver glass plate negative

Image: 17.6 x $12.6 \mathrm{~cm}$; Glass support: 17.6 x $12.6 \mathrm{~cm}$

(Credit: Robert J. Flaherty/ Library and Archives of Canada/ PA-500772)

\footnotetext{
${ }^{79}$ It is unknown whether Flaherty controlled the cropping and the production of his photogravures, however it has been stated that he employed a darkroom assistant in Jo-Anne Birnie Danzker, Robert Flaherty: Photographer / Filmmaker, 86, catalogue 33 and Robert J. Christopher, Robert and Frances Flaherty, 408, footnote 38 .
} 
(Fig.43)

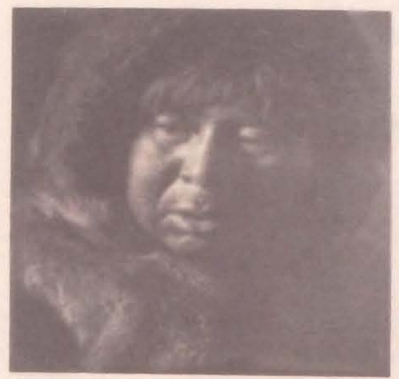

Sapa, Sikoslingmuit Eskimo of Southern Baffin Land

Photogravure

Image: $19.2 \times 16.4 \mathrm{~cm}$; Sheet: $50.5 \times 33 \mathrm{~cm}$

AGO 92/89.9

\section{Organization of the negatives and dissemination of the photographs and photogravures}

At the top left corner of the negative (fig. 2), there is a white piece of paper adhered to the glass, inscribed with the numbers " 399 " crossed out in black ink. This could possibly be part of the catalogue system that Frances planned as is indicated by an entry in her diary, November 4, 1915, where she wrote (written as if it were a letter to Flaherty):

"The negative of the one I consider your best portrait, far and away above the others, is missing. Small wonder when such wonderful care is taken of them. Your friend Mr. Booth, and I had a conversation on the same subject, both foaming at the mouth, with the result that I am having some boxes made such as he has for his plates, and have plans for a cataloguing system to keep track of them."

Other glass plate negatives examined also have pieces of paper with numbers crossed out. Presumably, they were replaced with a subsequent numbering system as the 
lower right has another alpha-number inscription, "FN2923" which were devised by Frances Flaherty and David Flaherty (Flaherty's brother). ${ }^{81}$

The number of prints Flaherty made from each negative is unknown because there is not an accurate concordance of his prints in public collections. The vintage prints that exist today are rare, as many are "dispersed and lost". 82 Flaherty gave his photographs away casually, mostly to family, friends and his portrait sitters, and on at least one occasion when he was unable to pay for room and board, he is thought to have given the landlady photographs instead.

The photogravure belongs to the portfolio, Camera Studies of the Far North. They were available in sets of six. However, the buyer had the option of choosing six gravures from a choice of eighteen. There is no documentation of how the portfolio was marketed to consumers, but every set included a colophon page or spread (Fig. 48 and Fig. 49: appendix A) which indicated that G.P. Putnam's Sons, New York, were the publishers and distributors of the portfolios. ${ }^{83}$

\section{Unknown photographs}

There are two photographs associated with the Flaherty collection at AGO, Huskies on Ice (fig.44: catalogue 44) and a four-part panorama of Moose Factory (catalogue 45). The texture of the Huskies photograph is semi-matte and its surface smoother than the rest of the gelatin silver prints in the collection. While searching through the Visual Indexes of Flaherty's work in the north, I found the same image as the

\footnotetext{
81 Dr. Jack Coogan, e-mail message to author, July 7, 2010.

82 Jo-Anne Birnie Danzker, Robert Flaherty, 6.

${ }^{83}$ A label for the colophon reads: "The remaining twelve photographs are for sale by G.P Putnam's Son's..."
} 
Huskies. During my visit to LAC, I was able to confirm that the photograph (fig.45) was deposited at LAC with the rest of the Flaherty works on loan from Claremont and that this photograph appears identical to the one at AGO; the framing is the same and type of photographic paper exhibit the same surface. It is safe to conclude that this photograph in AGO collection was taken by Flaherty.

(Fig.44)

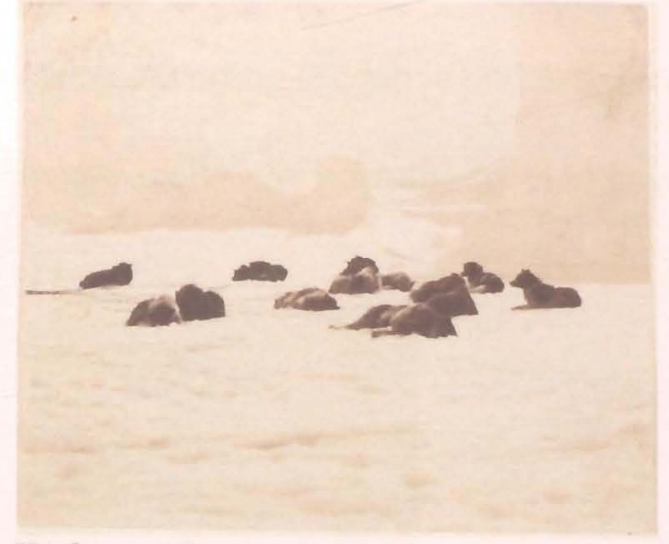

Huskies on Ice

Gelatin silver print

Image: $11.2 \times 13.5 \times \mathrm{cm}$; Sheet $11.2 \times 13.5 \mathrm{~cm}$ AGO 93/22
(Fig.45)

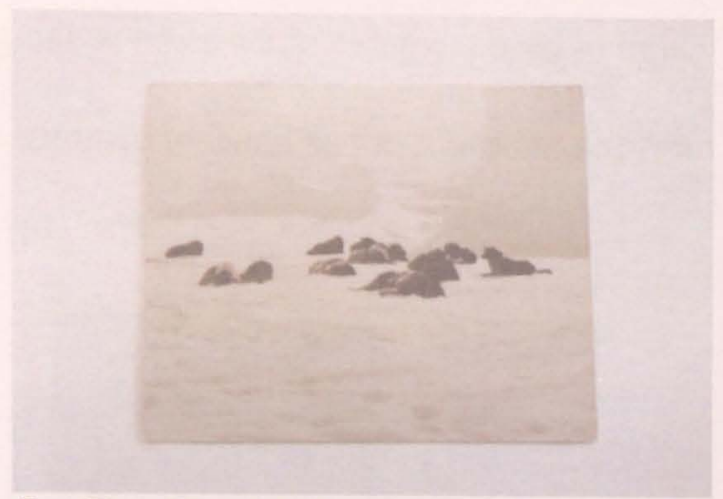

Dog Team Resting in Snow

Gelatin silver print

Image: 10.8 x $13.6 \mathrm{~cm}$; Sheet: $10.8 \times 13.6 \mathrm{~cm}$

(Credit: Robert J. Flaherty / Library and Archives of Canada/ PA-43511)

Four Views of Moose Factory was neither in the Visual Indexes nor in the LAC collection. However, throughout Flaherty's diaries, he often mentions his stopover in Moose Factory, where he took photographs of the "place and people". 84 This 'panorama' (catalogue 43) came to AGO as loose prints kept inside the album of Flaherty photographs, donated by Robb. There is a likelihood that these could have been taken by Flaherty but since this cannot be confirmed by any source at this time, the photographer remains unknown.

${ }^{84}$ Robert Christopher, Robert and Frances Flaherty, 50. 


\section{Frances Loring and Florence Wyle photographs}

The portraits of Loring and Wyle are very different from the other Flaherty photographs in the AGO collection; there are four cyanotypes, two-toned cyanotypes (brown-toned) and one toned gelatin silver bromide print. ${ }^{85}$ The papers are thin and matte. In Frances Loring with Shawl (fig.46: catalogue 47), the edge on the right-side of the print has a white line. This is most likely from the edge of a glass plate negative while contact printing (negative and paper touching one another while being exposed to light). Additionally, the portraits seem to have been trimmed by hand as the edges are uneven.

(Fig. 46)

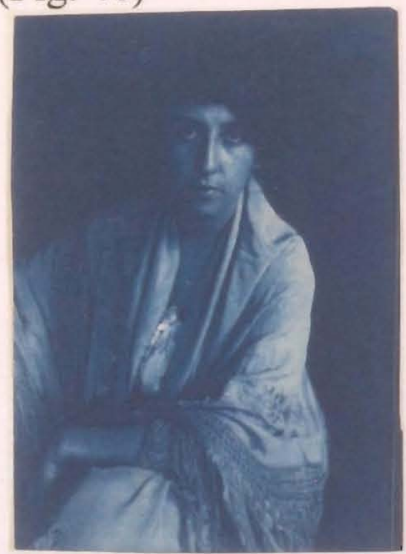

Frances Loring with Shawl cyanotype

Image: $19.3 \times 14.4 \mathrm{~cm}$; Sheet: $19.3 \times 14.4 \mathrm{~cm}$ AGO 86/111
(Fig. 47)

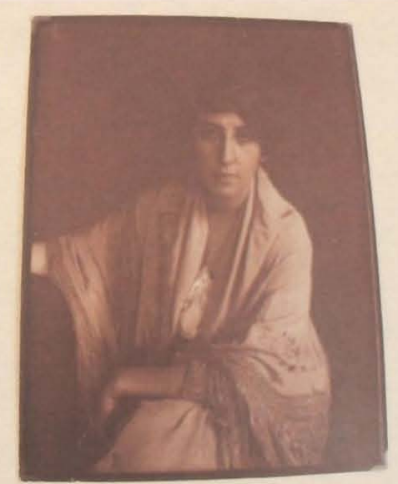

Frances Loring 1914-1915

Gelatin silver print (matted)

$22 \times 17 \mathrm{~cm}$

AGO Library and Archives - Special Collections Frances Loring and Florence Wyle fonds, Series 11: Photographs, box 15 - Loring and Wyle Biographical

The Estates of the Frances Loring and Florence Wyle donated the group of works, along with many other photographs that are in the AGO Special Collections. The related object (fig. 47) is different from the cyanotype. It is a gelatin silver print, printed on

85 Katharine Whitman, Conservator of Photographs at AGO, indicated that it is possible that cyanotypes could be toned. 
heavier paper and is likely toned. Compared to this gelatin silver print, the cyanotype image is not centred with a portion of Loring's arm no longer visible.

A revealing entry from Frances Flaherty's diary written on July $1915^{86}$ describes her and Flaherty's encounter with Loring and Wyle: "No dinner to get today; we are having it at the studio with the girls. Frances Loring and I met at the Arts and Letters Club last winter [1914]. ${ }^{87}$ She also mentions in the same entry a photograph of Wyle: "It was their [Loring and Wyle] picture I sent you; Florence Weil[sic] (in the kimono) is going down the river with us." ${ }^{, 88}$ It is probable that the photograph she was referring to was one of the three portraits of Wyle (two are with Loring) in the AGO collection (catalogue 49-51). In these photographs, Wyle is dressed in a long wide-sleeve wrap dress that resembles a kimono. This piece of information indicates that all the portraits were likely taken in 1914 or 1915.

${ }^{86}$ The speech of this diary entry seems to be expressed as a letter to France Flaherty's sister, Dottie. However, it is not indicated in Christopher's biography whether this was an actual letter that was sent. ${ }^{87}$ Robert Christopher, Robert and Frances Flaherty, 225.

88 Ibid, 256. 


\section{Conclusion}

This thesis has not only provided detailed and verified information on the fiftyone photographs and photogravures by Robert J. Flaherty at AGO, but has also provided an overview of Flaherty's photography based on secondary literature and drawing upon entries in the Flahertys' diaries from 1910-1922.

Researchers will now be able to draw upon the catalogue to learn more about the important Flaherty works at AGO. There are still aspects for further research on Flaherty's photographic activity that is documented in his expedition diaries. A thorough investigation of them would uncover more information regarding when the prints were taken, as many of his photographs are still given an eleven year date range, from 19101921 , because those were the years that Flaherty travelled to the north.

Researchers could also extend my analysis of Flaherty's work in the AGO collection to other related objects at LAC and other collections using this catalogue as the basis. Ideally, this research would result in a catalogue raisonné of all the Flaherty photographs in public institutions around the world, which would indicate where his prints are, as well as how many photographs survives compared to the negatives at LAC on loan from Claremont University. 


\section{Bibliography}

Barsam, Richard. The Vision of Robert Flaherty: The Artist as Myth and Filmmaker. Bloomington and Indianapolis: Indiana University Press, 1988.

Birnie Danzker, Jo-Anne. Robert Flaherty: Photographer / Filmmaker (The Inuit 19101922). Vancouver: Vancouver Art Gallery, 1979.

---.-.. "Robert Flaherty/ Photographer." Studies in Visual Communication, 6, Number 2, (Summer 1980), 5-31.

Calder-Marshall, Arthur. The Innocent Eye: The Life of Robert J. Flaherty. New York: Harcourt, Brace \& World, 1963.

Cameron, Elspeth. And Beauty Answers: The Life of Frances Loring and Florence Wyle. Toronto: Cormorant Books, 2007.

Christopher, Robert, J. Robert and Frances Flaherty: A Documentary Life, 1883-1922. Kingston and Montreal: McGill-Queen's University Press, 2005. . "Through Canada's Northland: The Arctic Photography of Robert J. Flaherty," in J.C.H King and Henrietta Lidchi, Imaging the Arctic. London: British Museum Press, 1998.

Dewan Janet. The Photographs of Linnaeus Tripe: A Catalogue Raisonné. Toronto: Art Gallery of Ontario, 2003.

Eber, Dorothy Harley. “On Koodjuk's Trail." Natural History 88. January 1979.

Eskind, Andrew $\mathrm{H}$. et al. International Photography: George Eastman House Index to Photographers, Collections, and Exhibitions, vol. 2. New York: G.K. Hall; London: Prentice Hall International, 1998.

Flaherty, Robert J. "The Belcher Islands of Hudson Bay: Their Discoveries and Exploration." The Geographical Review. Vol. 5, No. 6, June 1918, 433-458. American Geographical Society. http://www.jstor.org/stable/207804 (accessed October 13, 2009).

. "How I Filmed Nanook of the North." The World's Work, September 1922.

-.---.--.. "Life Among the Eskimos." The World's Work, October 1922 in collaboration with Frances Hubbard Flaherty. My Eskimo Friends. Garden City and New York: Doubleday, Page \& Company, 1924. 
------. "Two Traverses Across Ungava Peninsula, Labrador." The Geographical Review, volume VI, number 2, (August 1918), 116-132. American Geographical Society. http://www.jstor.org/stable/207475 (accessed February 13, 2010).

------... "Wetalltook's Islands." The World's Work, February, 1923.

-------.. "Winter on Wetalltook's Islands." The World's Work, March, 1923.

Griffith, Richard. The World of Robert Flaherty. New York: Duell, Sloan and Pearce, 1953.

Gunthert, André and Michel Poivert. L'Art de la Photographie des Origines à nos Jours. Paris: Editions Citadelles-Mazenod, 2007.

Harris, David. "The Mira Godard Study Centre, Ryerson University Print Collection Cataloguing Manual." Computer printout, School of Image Arts, Ryerson University, 2001 .

Murphy, William T. Robert Flaherty: A Guide to References and Resources. Boston, Massachusetts: G.K. Hall \& Co., 1978.

Rotha, Paul with the assistance of Basil Wright. "Nanook of the North." Studies in Visual Communication, 6, Number 2, (Summer 1980), 33-60.

Ruby, Jay. "The Aggie Must Come First: Robert Flaherty's Place in Ethnographic Film History" in Picturing Culture: Explorations of Film and Anthropology. Chicago: University of Chicago Press, 2000.

Sisler, Rebecca. The Girls: A Biography of Frances Loring and Florence Wyle

Toronto: Clark, Irwin \& Company, 1974.

Therrien, Michèle. "Archives Revillon Photos, Inventaire Analytique." Photocopy, Archives Publiques du Canada, Paris, February 1984.

Van Dongen, Helen. “Robert J. Flaherty 1884-1951." Film Quarterly. Vol. 18, No.4 Summer, 1965, 2-14. University of California Press. http://www.jstor.org/stable/1210252 (accessed August 16, 2010). 


\title{
Appendix A
}

This appendix documents the portfolio, Camera Studies of the Far North, based on copies at AGO and LAC. The portfolios were published by G.P. Putmans' Sons in 1922; the gravures were printed by The American Gravure Company, N.Y.C.; they were available through G.P Putman's Son's, New York; and the images were copyrighted by Revillon Frères, N.Y.

The portfolios were sold in two forms: in sets of either six photogravures with a single text page or twelve phtogravures with a fold leaf. There are slight differences between the two versions.

The folded leaf, accompanying the sets with twelve gravures, bears a title on the front (fig. 48) that reads:

\author{
CAMERA STUDIES OF \\ THE FAR NORTH \\ TWELVE ENGRAVING OF \\ ESKIMOS AND INDIANS \\ OF THE SUB-ARCTIC \\ ROBERT J. FLAHERTY \\ F.R.G.S. \\ G.P PUTNAM'S SONS \\ NEW YORK \& LONDON \\ 1922
}

Inside is a text signed by Flaherty describing his photographs (figs. 49 and 50).

The single page colophon, accompanying sets of six photogravures, does not bear the title, Camera Studies of the Far North but instead has a text signed by the "Revillon Frères" which indicates that the "six copper-plate engravings" are from a collection of 
eighteen. In the lower left corner, there is a small label attached to the page (fig. 52) that reads:

\author{
"The remaining twelve photographs \\ are for sale by G.P. PUTNAM'S SONS \\ 2 West $45^{\text {th }}$ Street, New York"
}

The texts describes where Flaherty had taken these images and that the subjects included Nascaupie Indians but mostly "Eskimos" of Eastern Canada and Baffin Land.

Purchasers were free to select the individual plates for the six and twelve photogravure sets. Since there is no apparent order to the eighteen photogravures, they are simply listed and reproduced here for the first time in their entirety.

\title{
Portfolios and Plates
}

Colophon - Folded leaf

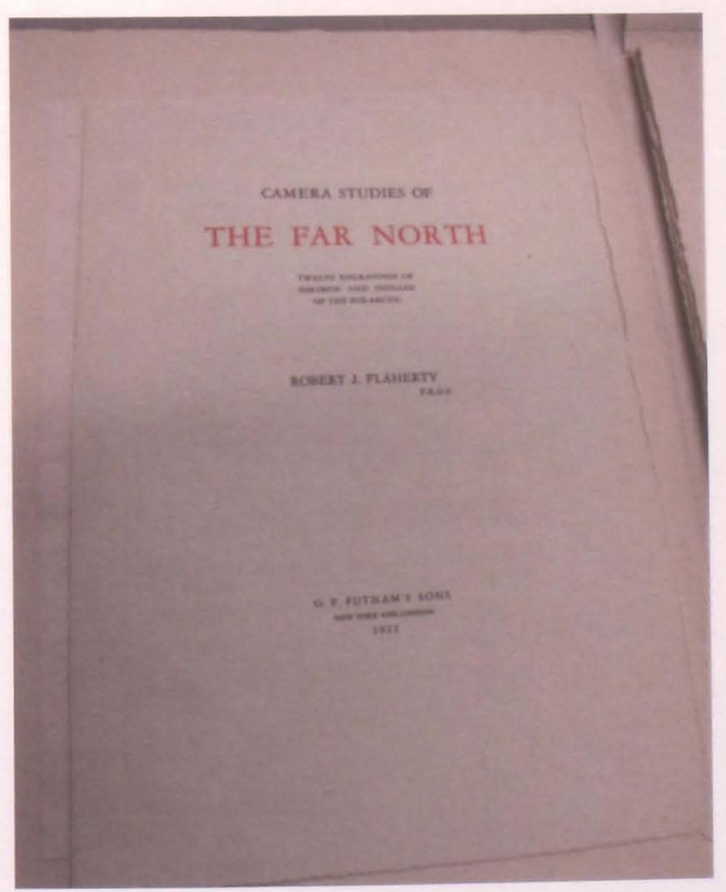

(Fig. 48) Camera Studies of the Far North colophon for twelve photogravures (title leaf) Sheet: $35.5 \times 25.5 \mathrm{~cm}$ 
National Library Collection, LAC

NLC: E77.5 F53 1922

Amicus No. 10182781

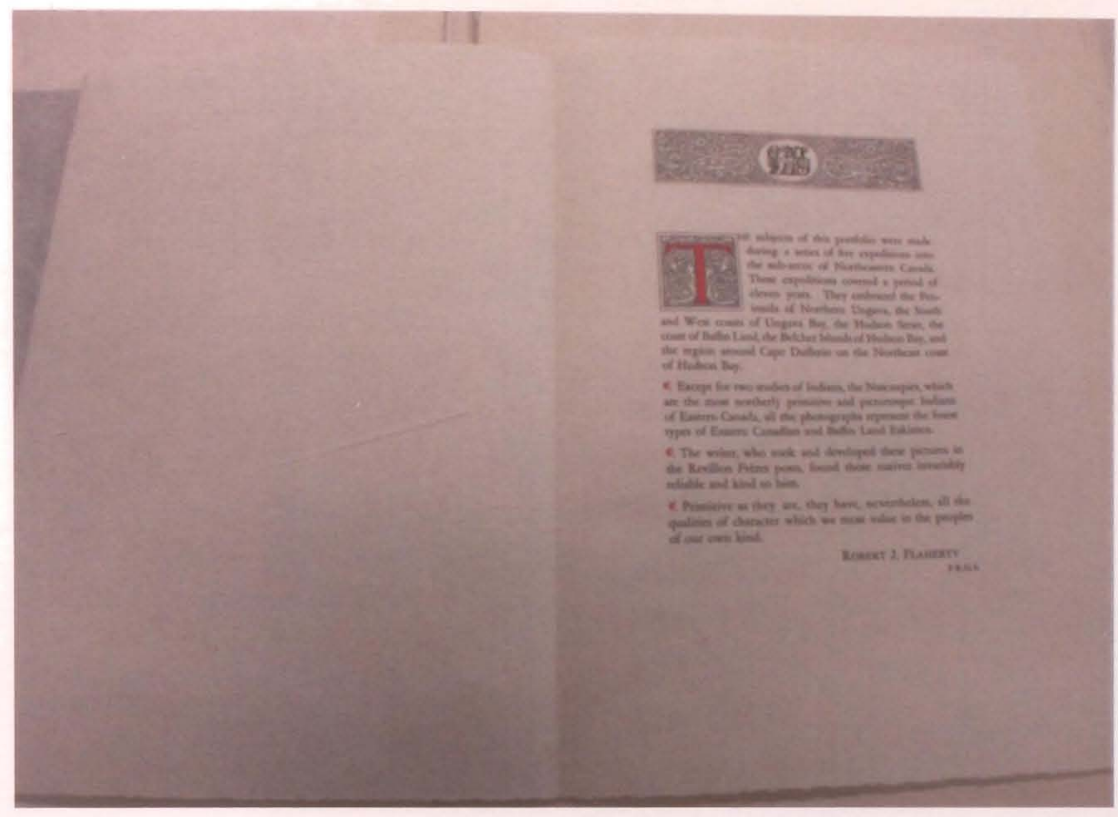

(Fig. 49) Camera Studies of the Far North Colophon for twelve photogravures (second leaf) Sheet: $35.5 \times 51 \mathrm{~cm}$ 

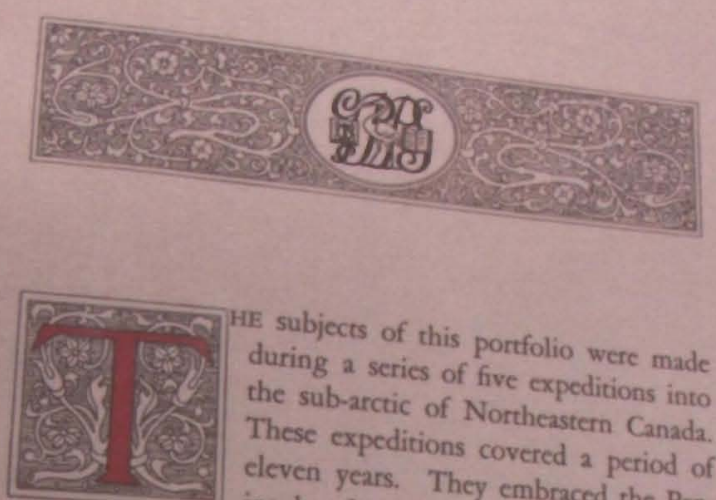

during subjects of this portfolio were made the sub a series of five expeditions into These expeditions Northeastern Canada. eleven years. They covered a period of insula of $\mathrm{Nor}$. They embraced the Penand West coasts of Ungava, the South coast of Baffin Land, the Hava Bay, the Hudson Strait, the the region around Cape Duffer Islands of Hudson Bay, and of Hudson Bay.

I Except for two studies of Indians, the Nascaupies, which are the most northerly primitive and picturesque Indians of Eastern Canada, all the photographs represent the finest types of Eastern Canadian and Baffin Land Eskimos.

The writer, who took and developed these pictures in the Revillon Frères posts, found those natives invariably reliable and kind to him.

C. Primitive as they are, they have, nevertheless, all the qualities of character which we most value in the peoples of our own kind.

ROBERT J. FLAHERTY

(Fig. 50) Detail of Camera Studies of the Far North colophon for sets of twelve photogravures (second leaf) 
Colophon - Single leaf

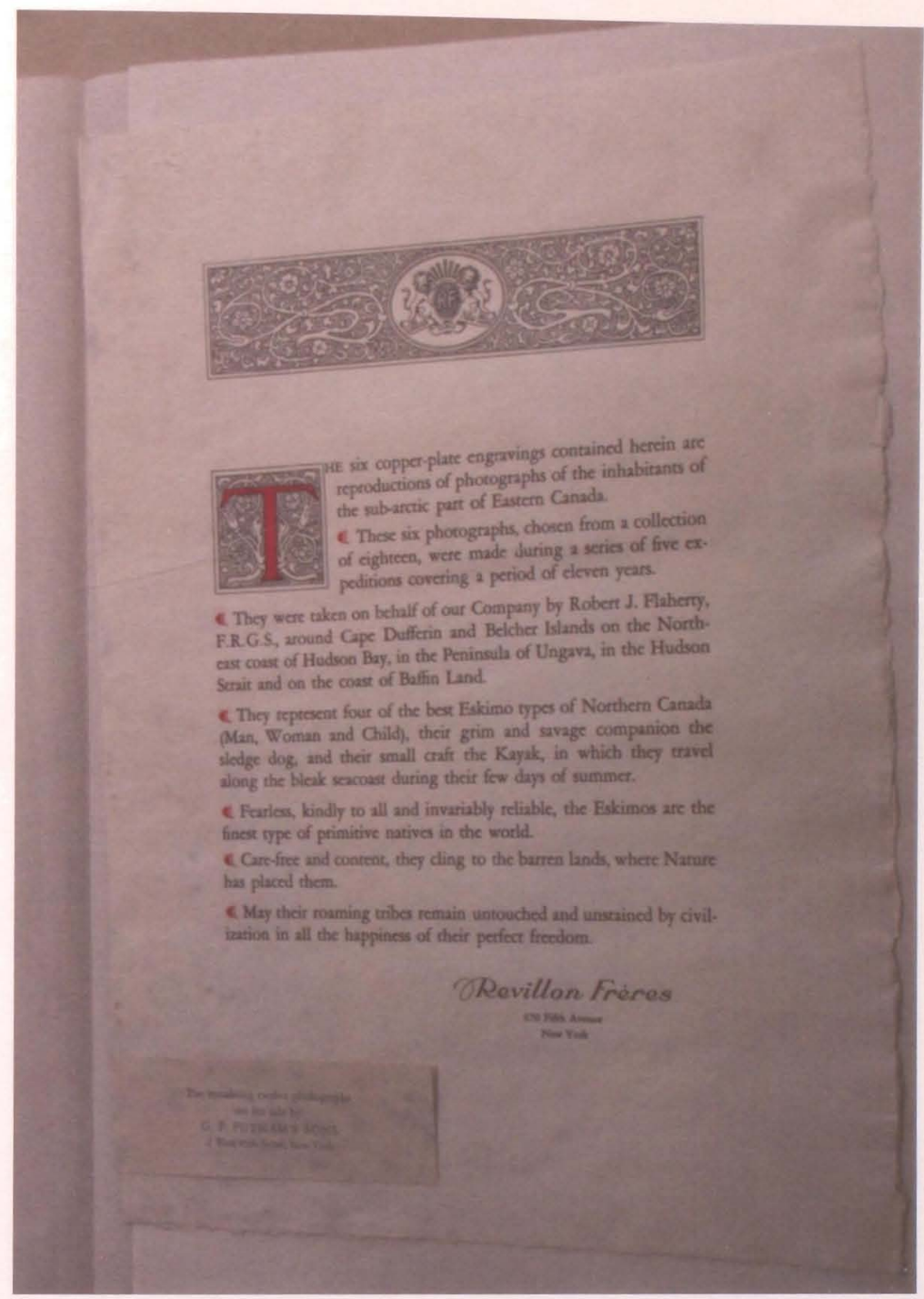

(Fig. 51) Camera Studies of the Far North colophon for sets of six photogravures Sheet: $35.6 \times 25.6 \mathrm{~cm}$

National Library Collection, LAC

NLC: E77.5 F53 1920z

Amicus No. 17279562 


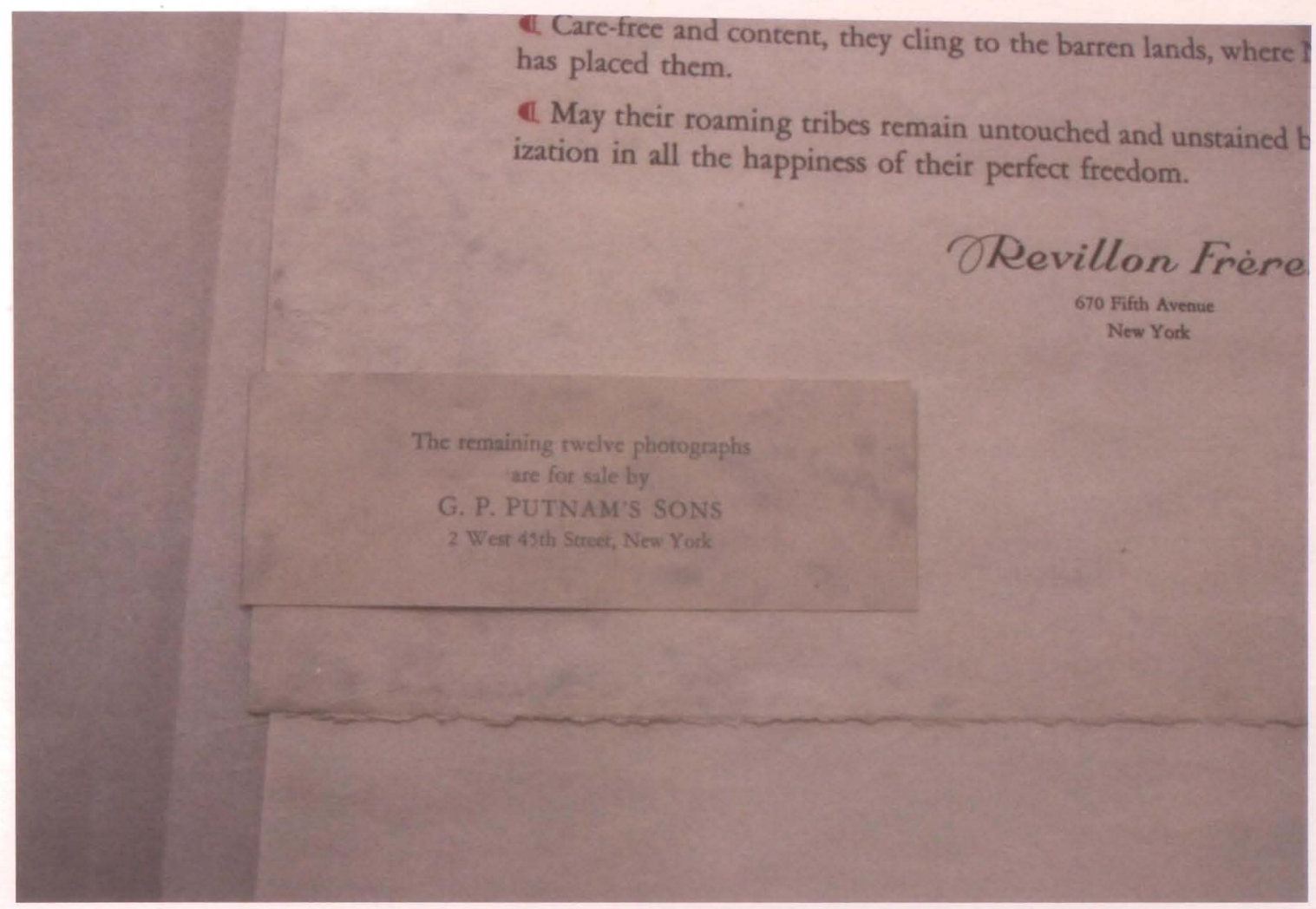

(Fig. 52) Detail of Camera Studies of the Far North colophon for six photogravures 
Eighteen Photogravures from Camera Studies of the Far North Portfolio (In no particular order)

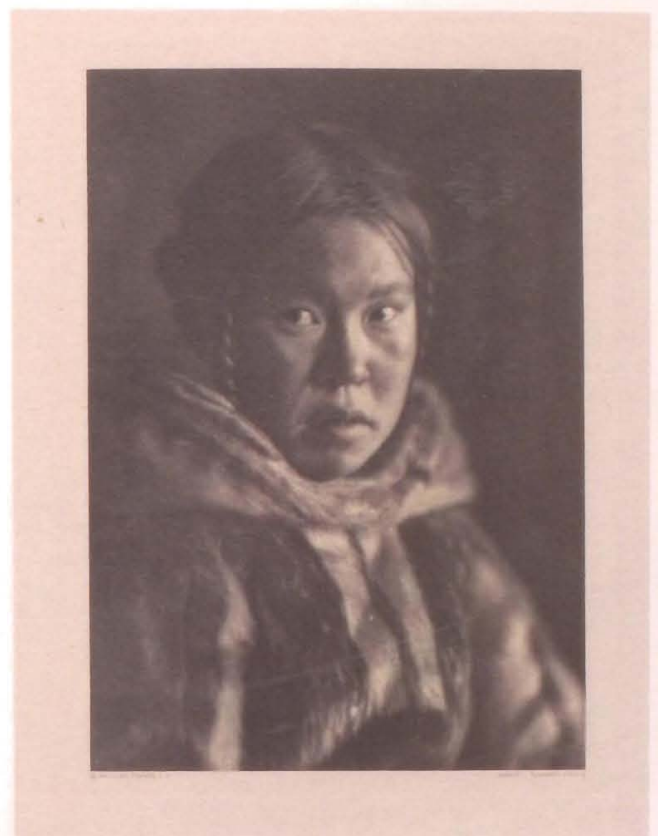

(Fig. 53) Canayou (The Sculpin). Sikoslingmuit Eskimo Girl, Southern Baffin Land AGO 92/89.11

(See catalogue 32)

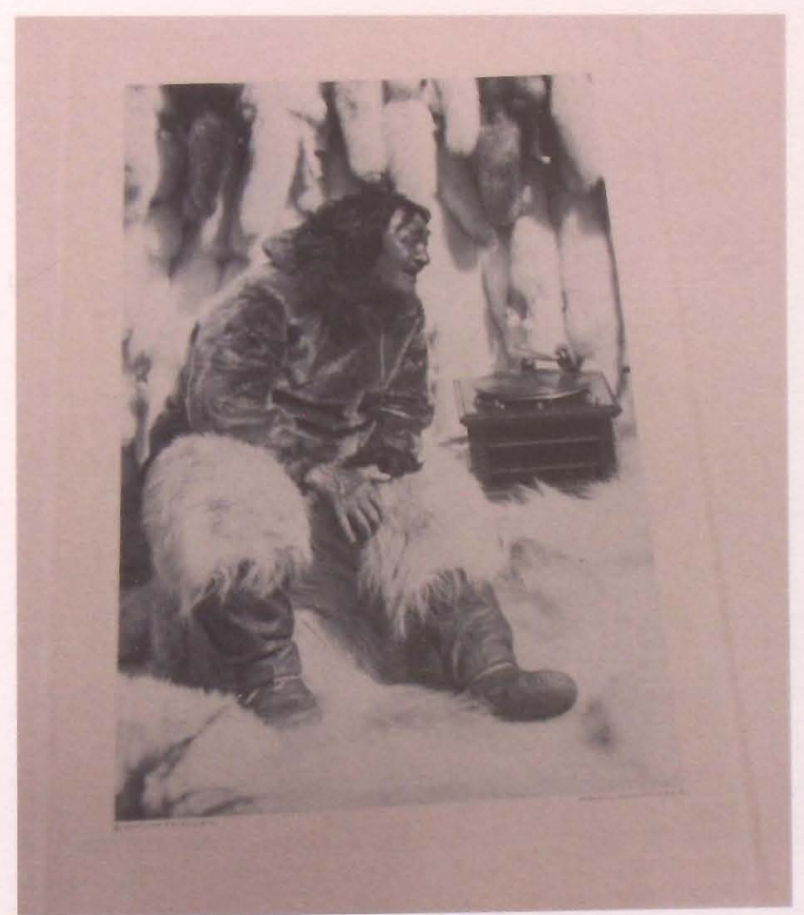

(Fig. 54) The Gramophone

National Library Collection, LAC

NLC: E77.5 F53 1922

Amicus No. 10182781 


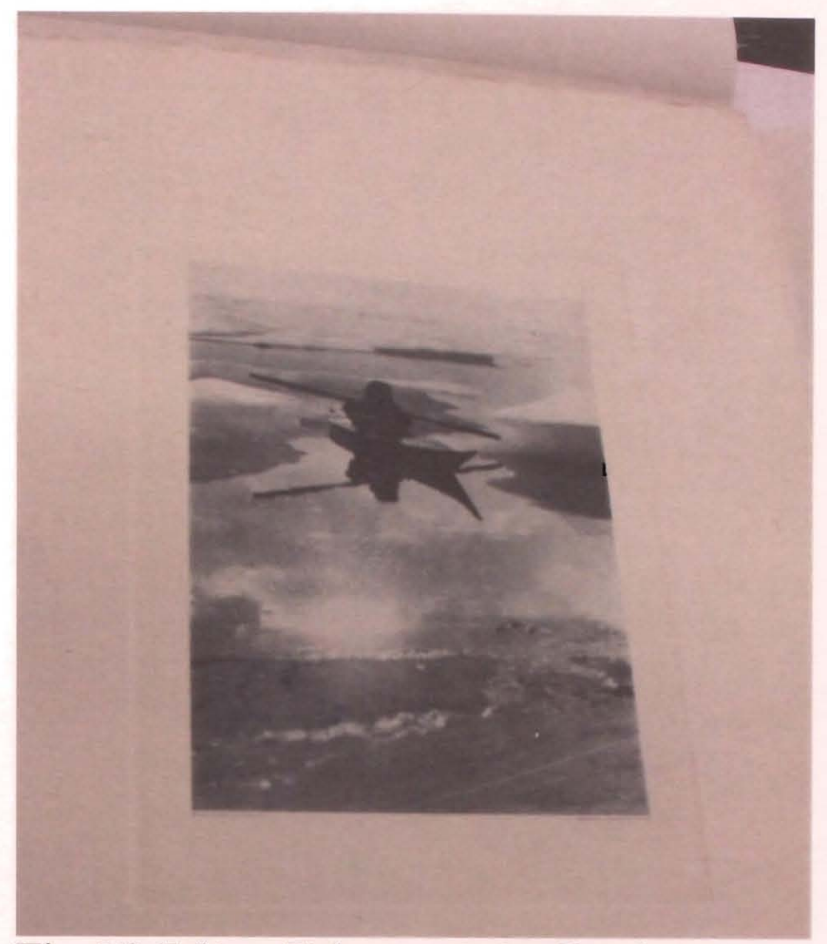

(Fig. 55) Eskimo Fisherman in his Kayak

National Library Collection, LAC

NLC: E77.5 F53 1922

Amicus No. 10182781

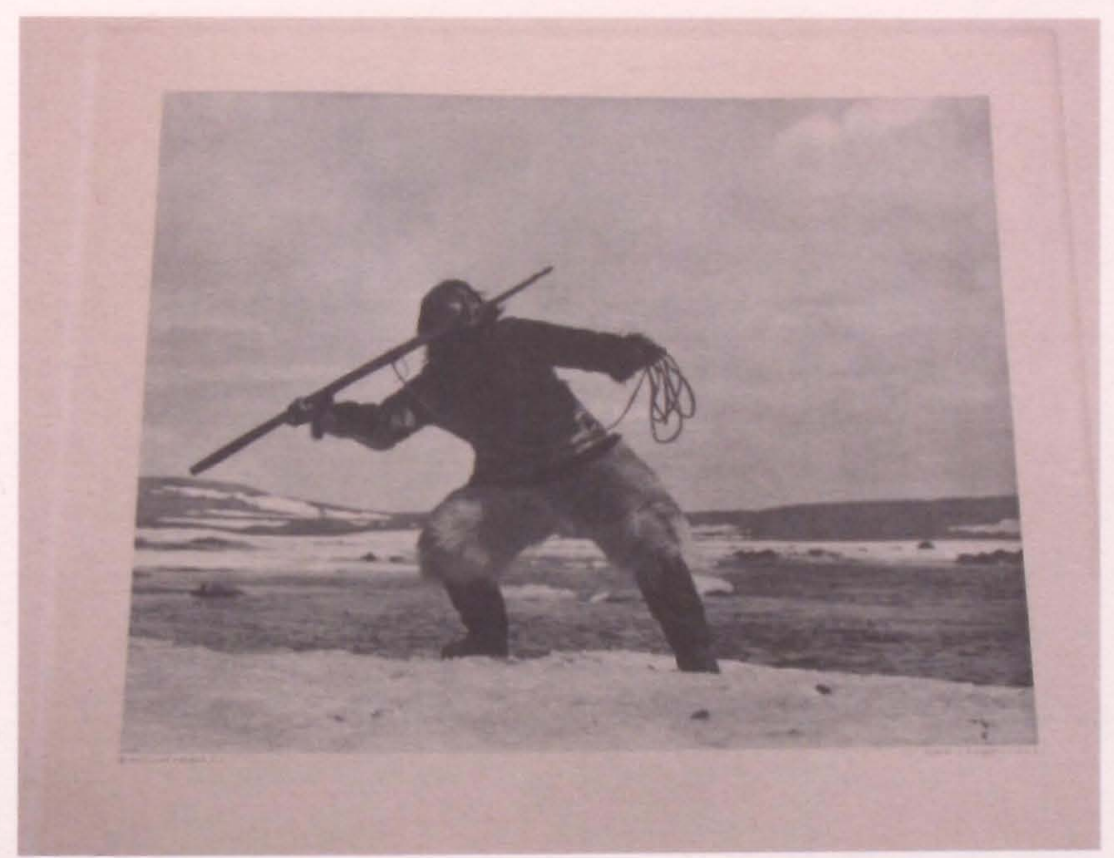

(Fig. 56) The Harpooner

National Library Collection, LAC

NLC: E77.5 F53 1922

Amicus No. 10182781 


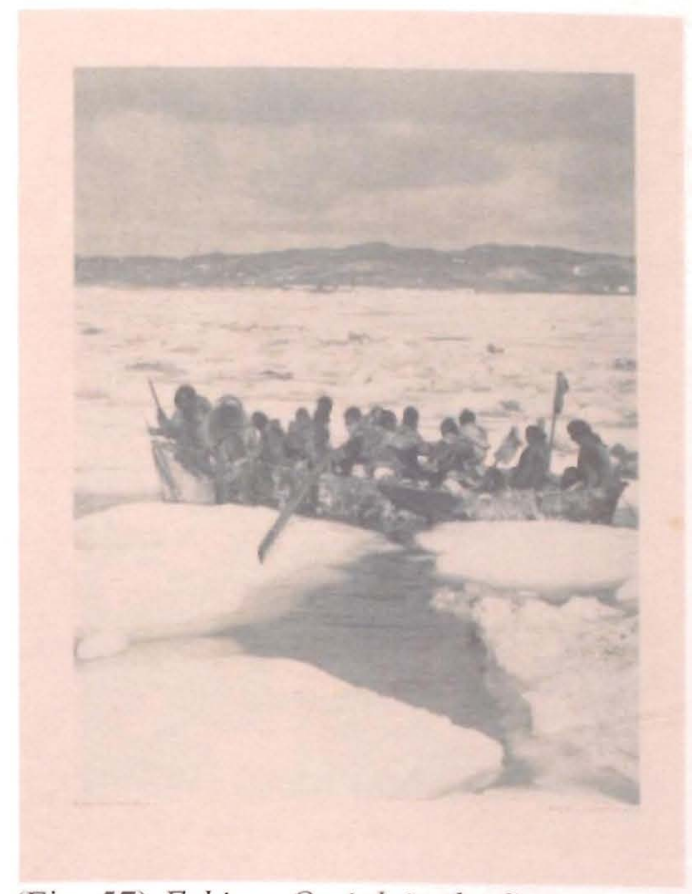

(Fig. 57) Eskimo Omiak in the Spring AGO 92/89.1

(See catalogue 24)

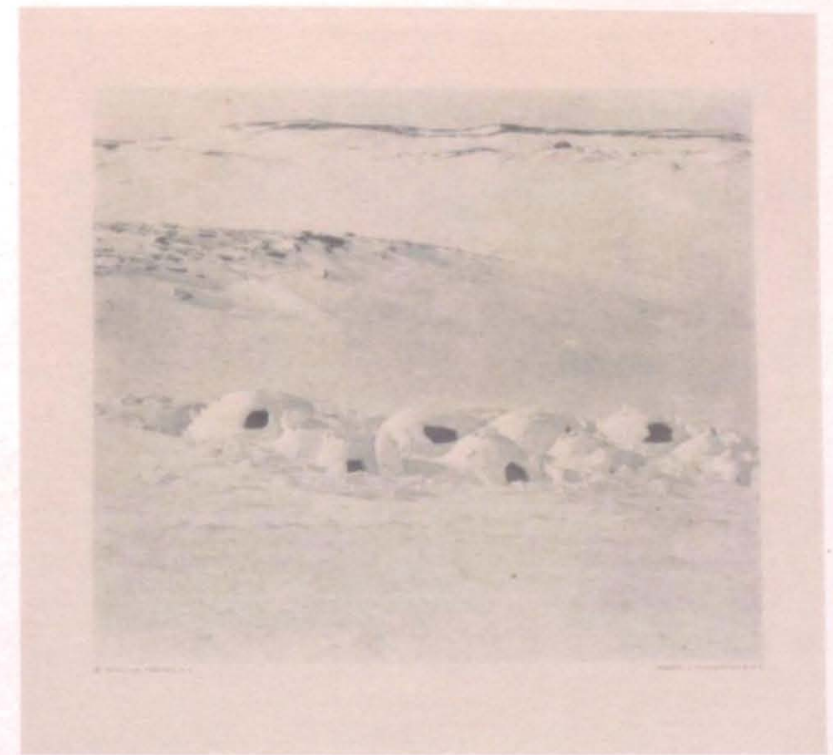

(Fig. 58) Abandoned Eskimo Village

AGO 92/89.5

(See catalogue 28) 


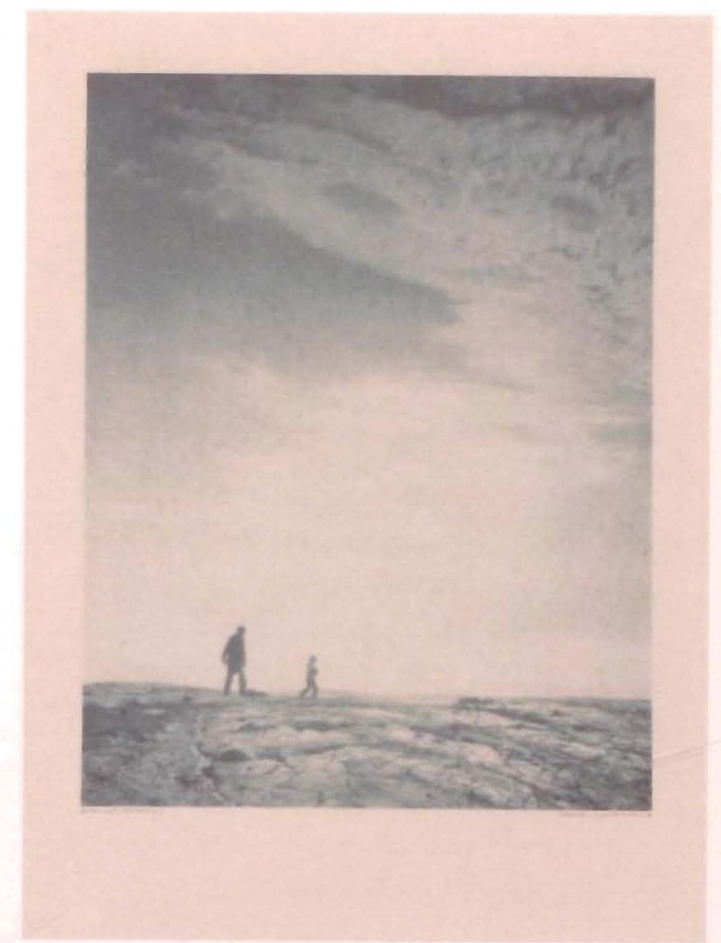

(Fig. 59) The Barren Lands, Northern Ungava AGO 92/89.3

(See catalogue 26)

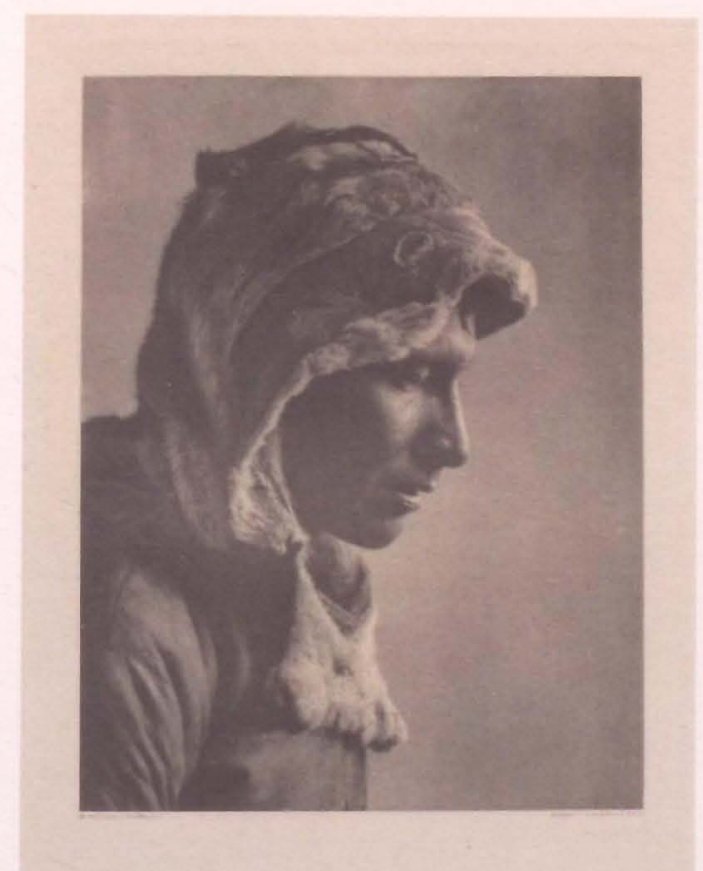

(Fig. 60) A Labrador Cree (Indian) Northern Labrador AGO 92/ 89.7

(See catalogue 29) 


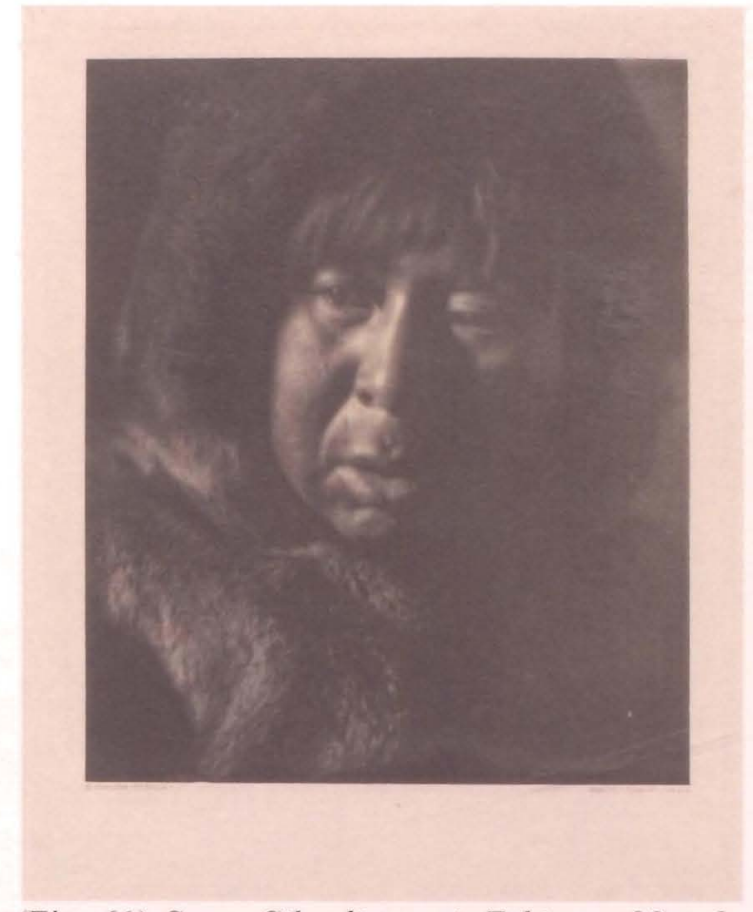

(Fig. 61) Sapa, Sikoslingmuit Eskimo of Southern Baffin Land AGO 92/89.9

(See catalogue 30 )

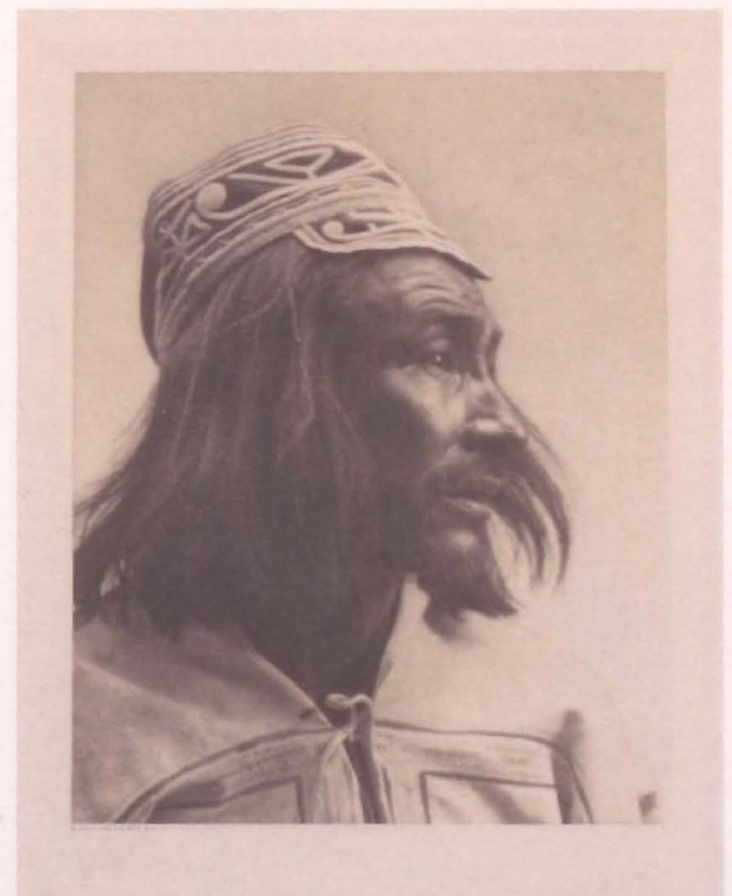

(Fig. 62) Nascaupie, Indian Chief, Northern Labrador AGO 92/89.10

(See catalogue 31) 


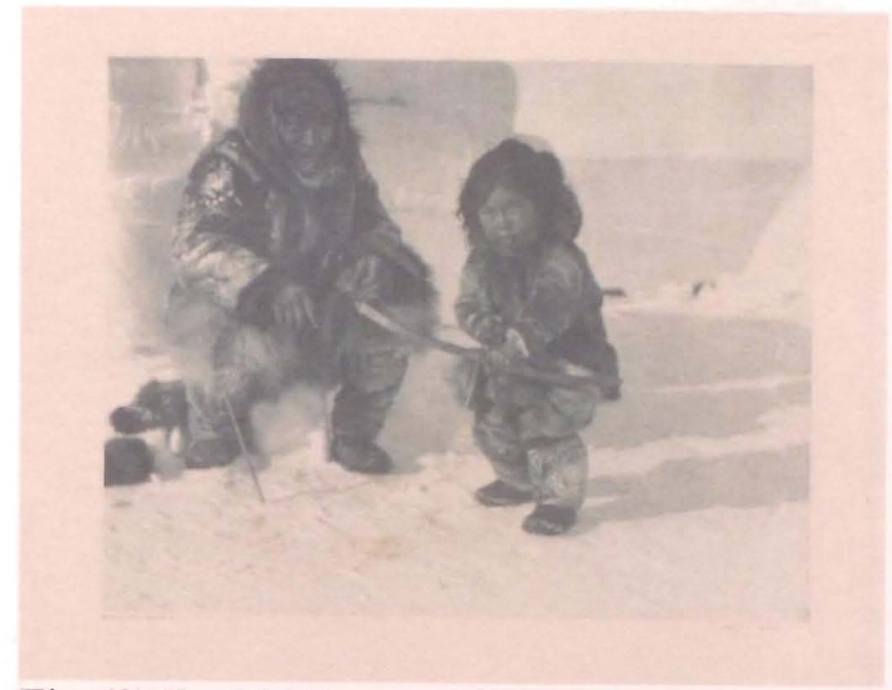

(Fig. 63) Youthful Hunter

AGO 92/89.4

(See catalogue 27)

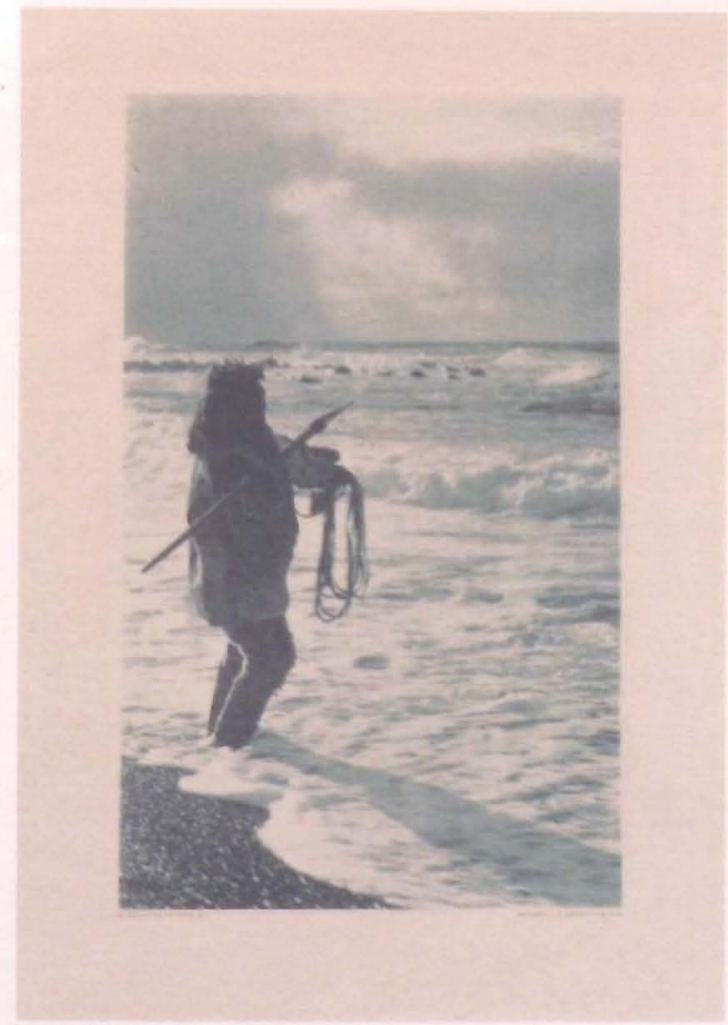

(Fig. 64) The Walrus Hunter

AGO 92/89.2

(See catalogue 25) 


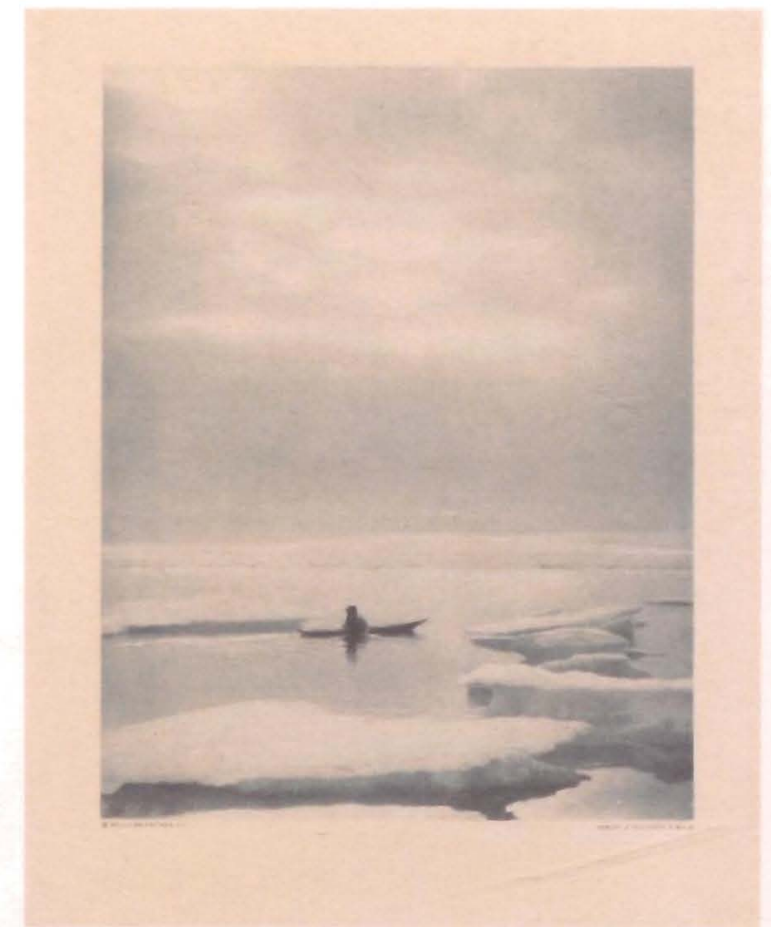

(Fig. 65) Summer (August): Eskimo Kayak in North Eastern Hudson Bay AGO 92/89.6 and 87/322

(See catalogue 35 and 36 )

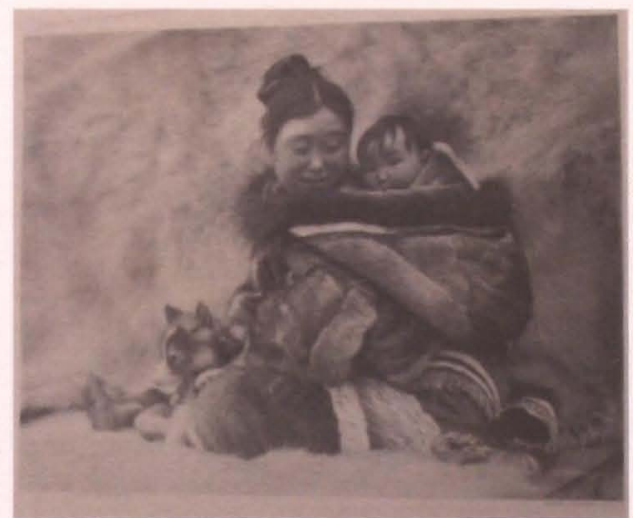

(Fig. 66) Nyla and Child: Eteeveemuit Eskimo of Cape Dufferin, Northwestern Ungava AGO 2007/159.4

(See catalogue 33) 


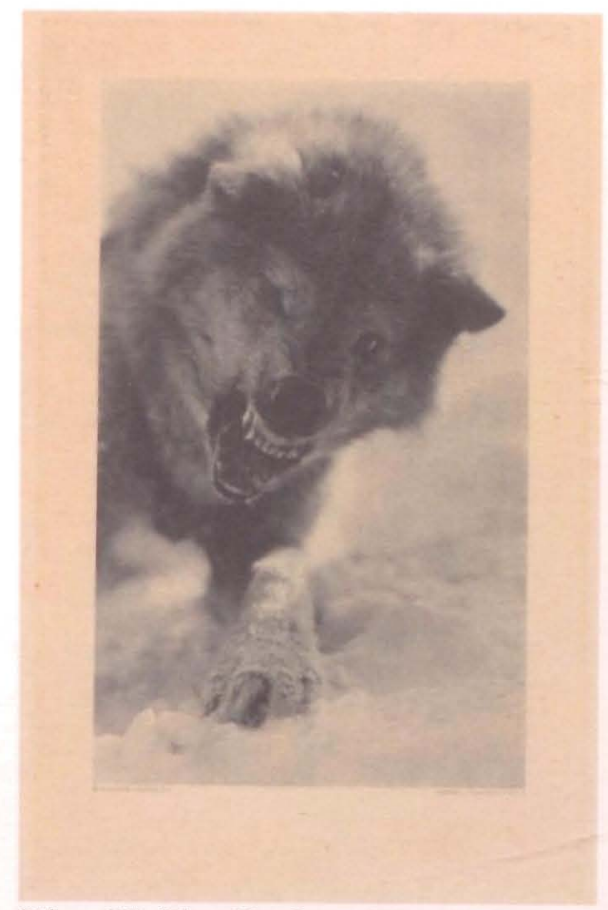

(Fig. 67) The Huskie: (The Wolf Dog of the Eskimos) AGO 87/324 and 2007/159.2

(See catalogue 39 and 40)

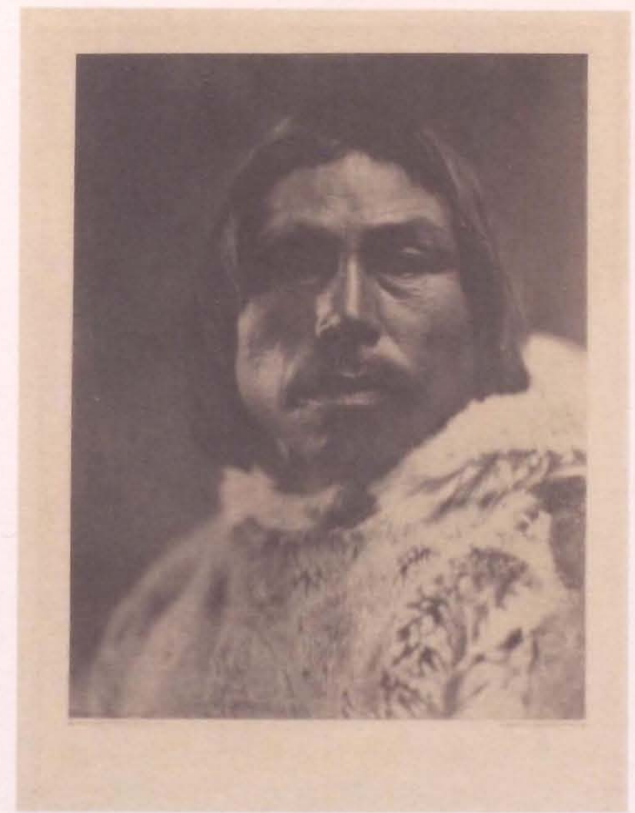

(Fig. 68) Tooktoo (the Deer), Chief of Sikoslingmuit Eskimos, Southern Baffin Land AGO 92/89.8 and 2007/159.1

(See catalogue 41 and 42) 


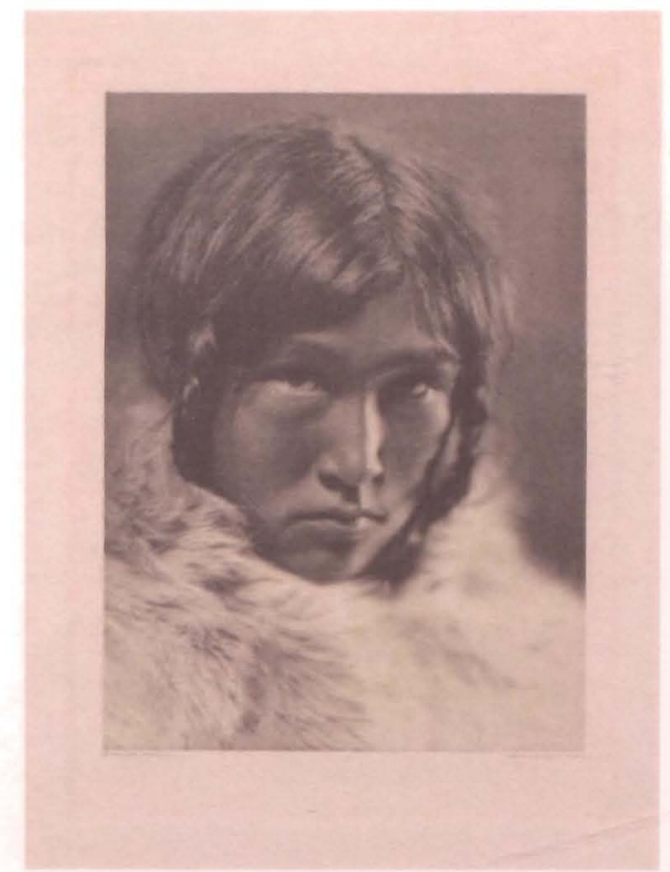

(Fig. 69) Allegoo (Shining Water), Sikoslingmuit Eskimo Woman, Southern Baffin Land AGO 2007/159.5

(See catalogue 34)

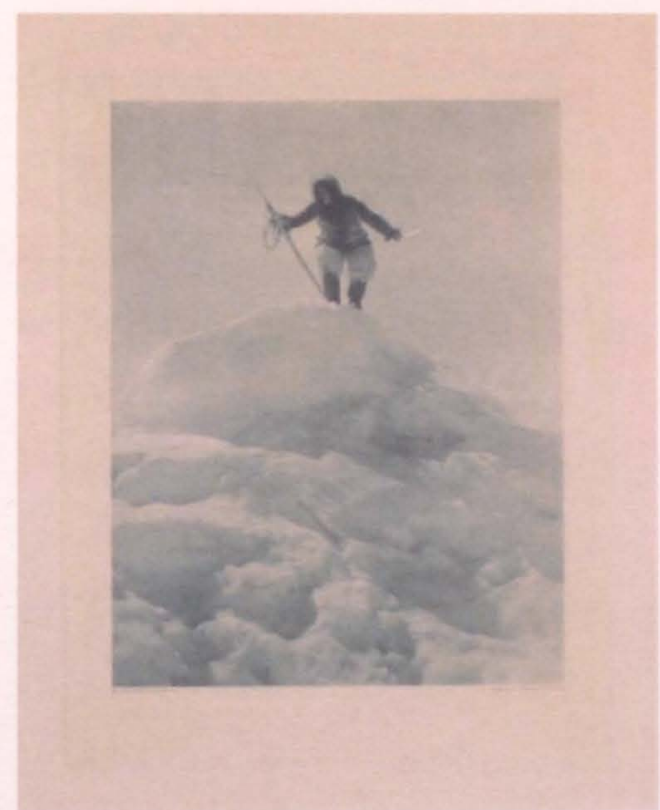

(Fig. 70) The Hunter, Eskimo in the Rough Ice Fields at Sea AGO 87/323 and 2007/159.3

(See catalogue 37 and 38) 


\section{APPENDIX B}

The following twenty photographs were originally contained in a "postcard" album that was donated by Gordon M. Robb and accessioned into the AGO in 1993. The photographs have been removed and the album has since been discarded by the AGO. ${ }^{89}$

1. AGO 93/280.1 (Catalogue 1)

2. AGO 93/280.2 (Catalogue 5)

3. AGO $93 / 280.3$ (Catalogue 6)

4. AGO 93/280.4 (Catalogue 7)

5. AGO 93/280.5 (Catalogue 8)

6. AGO 93/280.6 (Catalogue 9)

7. AGO 93/280.7 (Catalogue 10)

8. AGO 93/280.8 (Catalogue 11)

9. AGO 93/280.9 (Catalogue 12)

10. AGO 93/280.10 (Catalogue 13)

11. AGO 93/280.11 (Catalogue 14)

12. AGO 93/280.12 (Catalogue 15)

13. AGO $93 / 280.13$ (Catalogue 16)

14. AGO 93/280.14 (Catalogue 17)

15. AGO $93 / 280.15$ (Catalogue 18)

16. AGO 93/280.16 (Catalogue 19)

17. AGO 93/280.17 (Catalogue 20)

18. AGO 93/280.18 (Catalogue 21)

19. AGO 93/280.19 (Catalogue 22)

20. AGO 93/280.20 (Catalogue 23)

${ }^{89}$ A Polaroid photograph of the "postcard" album is in AGO registration file for object 93/280.1 (Unidentified, Man, Baffin Island). 


\section{Illustration Credits}

Illustrations in Catalogue 1-51 (excluding the figures) are provided by the Art Gallery of Ontario.

Illustrations indicated from Library and Archives of Canada (LAC) are on loan from The Robert and Frances Flaherty Study Center, School of Theology, Claremont University, Claremont, California, and were taken by me. Permission to use images was granted by the Study Center.

Map Illustrations are reproduced from Robert J. Christopher's Robert and Frances Flaherty: A Documentary Life, 1883-1922. Kingston and Montreal: McGill-Queen's University Press, 2005, between pages xxi and 5. Permission was granted by McGillQueen's University Press. 